Historic, Archive Document

Do not assume content reflects current scientific knowledge, policies, or practices. 

Forest Health Technology

Enterprise Team

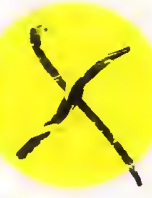

\section{Biology and Biological Control of Dalmatian and Yellow Toadflax}

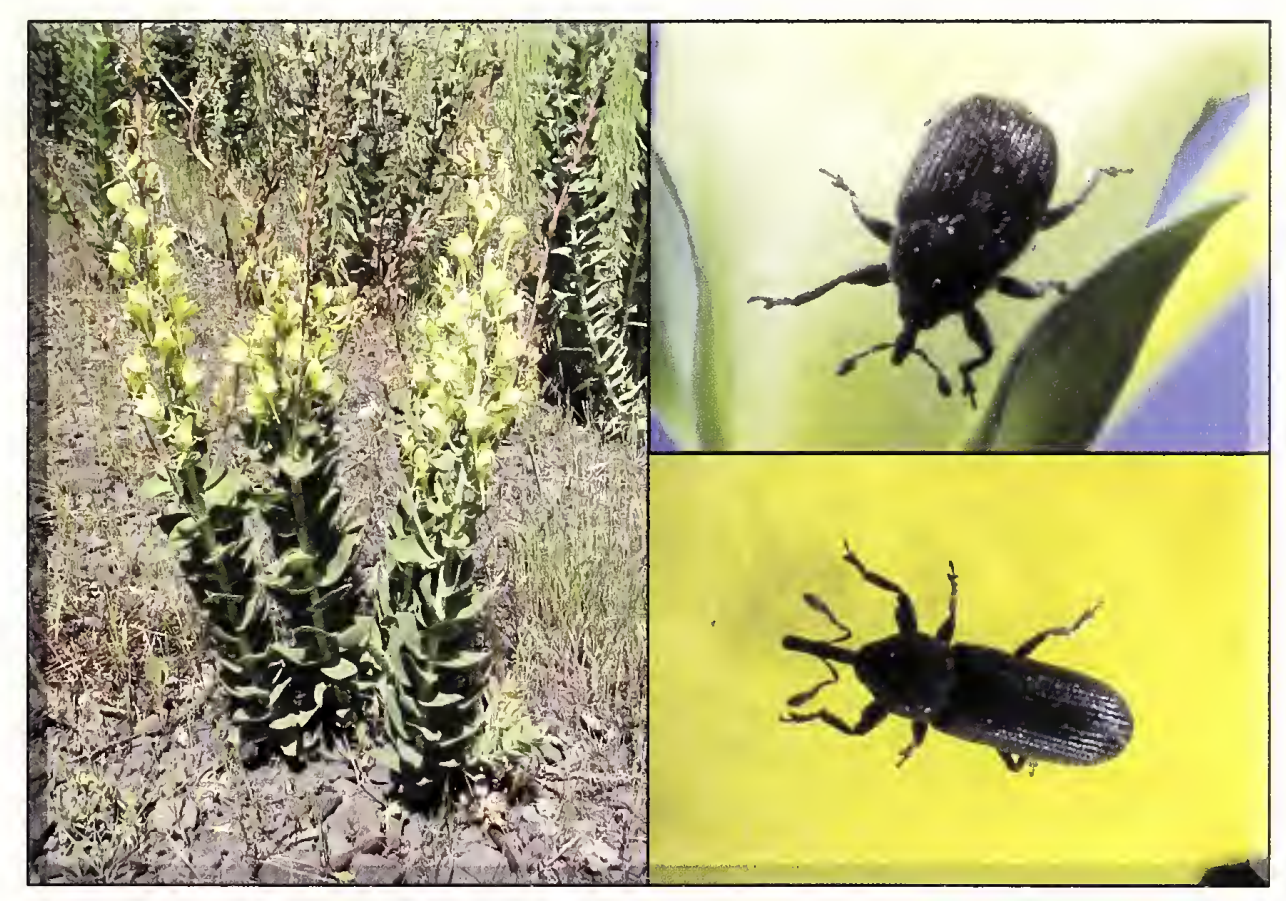

\section{Linda M. Wilson, Sharlene E. Sing, Gary L. Piper, Richard W. Hansen, Rosemarie De Clerck-Floate, Daniel K. Mackinnon, and Carol Bell Randall}


$\mathrm{T}_{1}$ The Forest Health Technology Enterprise Team (FHTET) was created in 1995 by the Deputy Chief for State and Private Forestry, USDA, Forest Service, to develop and deliver technologies to protect and improve the health of American forests. This book was published by FHTET as part of the technology transfer series.

http://www.fs.fed.us/foresthealth/technology/

Cover

UGA

All pl

www.f

codes 1

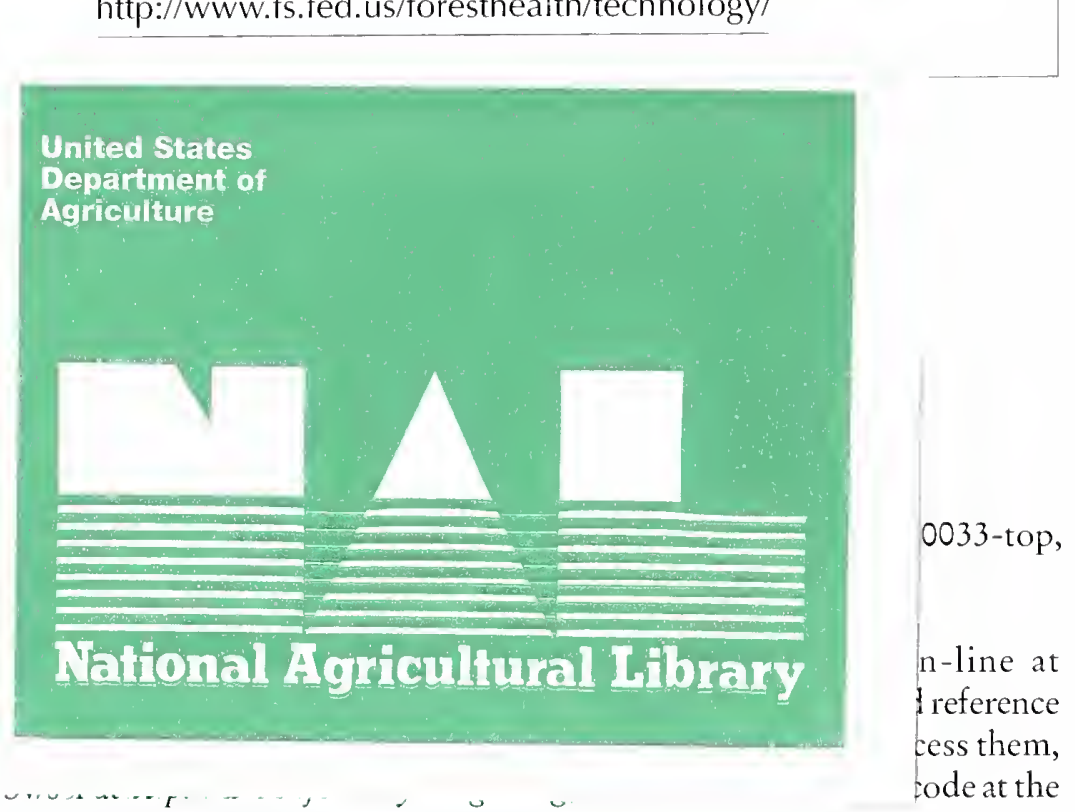

search prompt.

How to cite this publication:

Wilson, L. M., S. E. Sing, G. L. Piper, R. W. Hansen, R. De Clerck- Floate, D. K. MacKinnon, and C. Randall. 2005. Biology and Biological Control of Dalmatian and Yellow Toadflax. USDA Forest Service, FHTET-05-13.

The U.S. Department of Agriculture (USDA) prohibits discrimination in all its programs and activities on the basis of race, color, national origin, sex, religion, age, disability, political beliefs, sexual orientation, or marital or family status. (Not all prohibited bases apply to all programs.) Persons with disabilities who require alternative means for communication of program information (Braille, large print, audiotape, etc.) should contact USDA's TARGET Center at 202-720-2600 (voice and TDD).

To file a complaint of discrimination, write USDA, Director, Office of Civil Rights, Room 326-W, Whitten Building, 1400 Independence Avenue, SW, Washington, D.C. 20250-9410 or call 202-720-5964 (voice and TDD). USDA is an equal opportunity provider and employer.

The use of trade, firm, or corporation names in this publication is for information only and does not constitute an endorsement by the U.S. Department of Agriculture. 


\title{
Biology and Biological Control of Dalmatian and Yellow Toadflax
}

\author{
Linda M. Wilson ${ }^{1}$, Sharlene E. Sing ${ }^{2}$, \\ Gary L. Piper ${ }^{3}$, Richard W. Hansen ${ }^{4}$, \\ Rosemarie De Clerck-Floate ${ }^{5}$, \\ Daniel K. MaCKinnon ${ }^{6}$, \\ and Carol Bell Randall ${ }^{7}$ \\ U.S.D.A., NAL \\ MAR 302006 \\ CATALOGING PREP
}

In cooperation with Susan Turner (British Columbia Ministry of Forests), Robert Nowierski (USDA-CSREES), André Gassmann (CABI Bioscience),

Eric Coombs (Oregon Department of Agriculture), and Ruth Hufbauer (Colorado State University)

${ }^{1}$ Department of Plant, Soil and Entomological Sciences, University of Idaho, Moscow

2 USDA USFS Rocky Mountain Research Station, RM-4151, Bozeman, MT

3 Department of Entomology, Washington State University, Pullman

${ }^{4}$ USDA-APHIS-PPQ, Fort Collins, CO

${ }^{5}$ Agriculture and Agri-Food Canada, Lethbridge, Alberta

- Department of Bioagricultural Sci. and Pest Mgmt., Colorado State University, Fort Collins

7 USDA Idaho Panhandle National Forest, Coeur d'Alene, ID

For additional copies of this publication, contact:

Linda Wilson

University of Idaho

Moscow

Idaho

(208) 885-9489

lwilson@uidaho.edu
Richard Reardon FHTET, USDA Forest Service Morgantown West Virginia (304) 285-1566

rreardon@fs.fed.us 



\section{Contents}

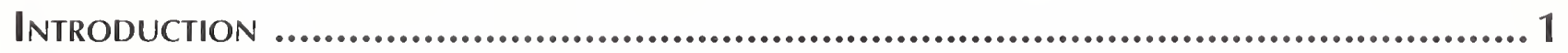

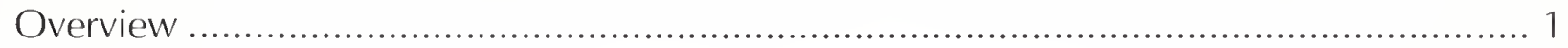

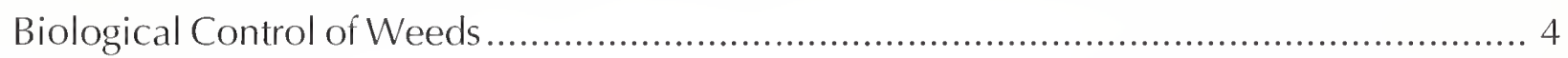

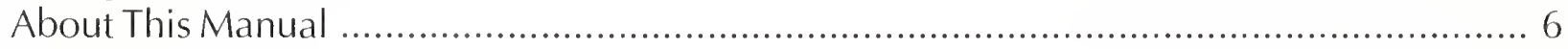

Chapter 1. Getting to Know the Toadflaxes ....................................................9 9

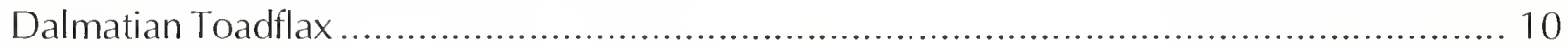

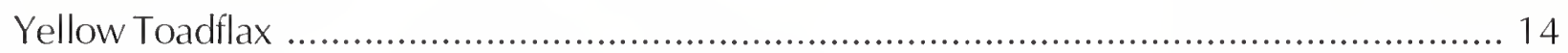

Chapter 2. Biology of Toadflax Biocontrol Agents ............................................ 20

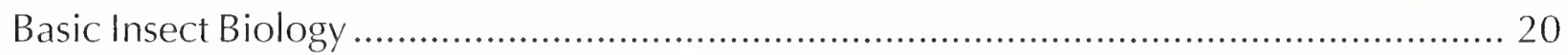

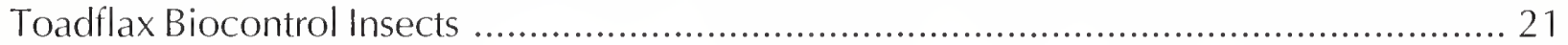

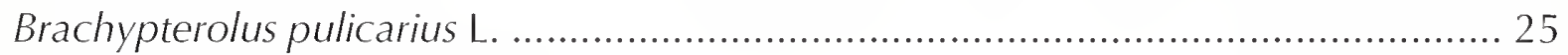

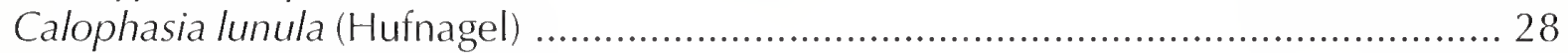

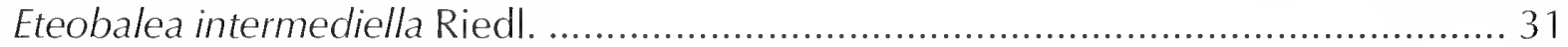

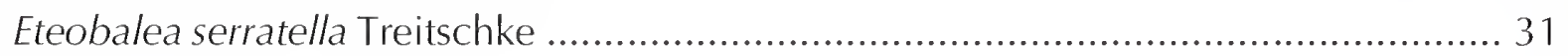

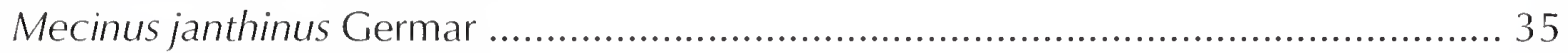

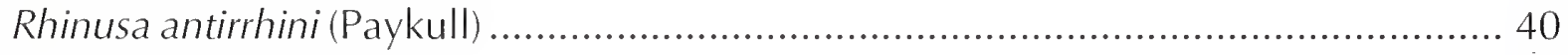

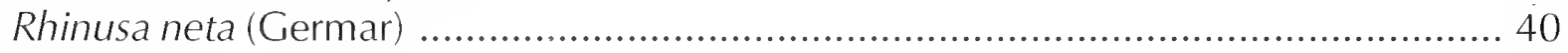

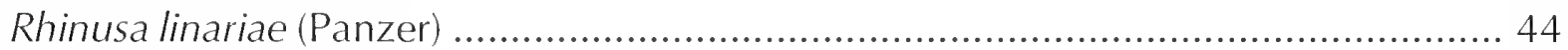

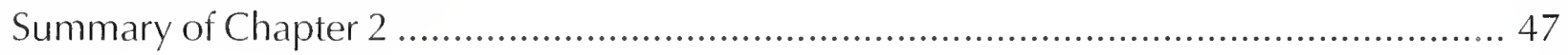

\section{Chapter 3. Developing, Implementing, and Managing a Toadflax Biological}

Control Program............................................................................ 51

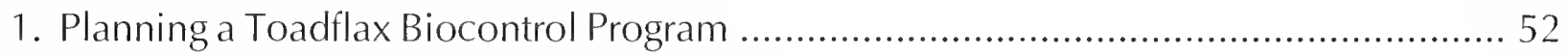

2. Deciding What Biocontrol Agent(s) to Release ........................................................ 53

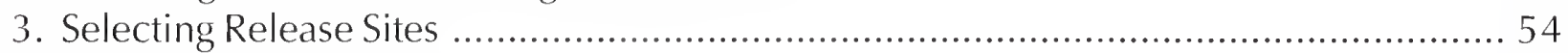

4. Obtaining Toadflax Biocontrol Agents ........................................................... 57

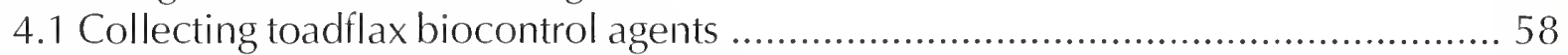

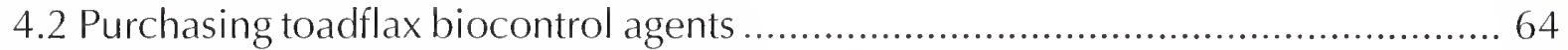

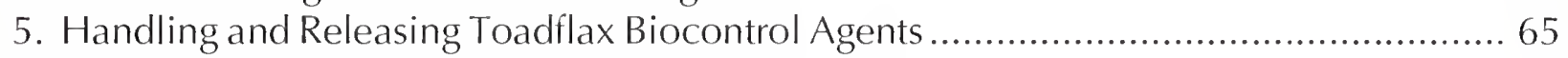

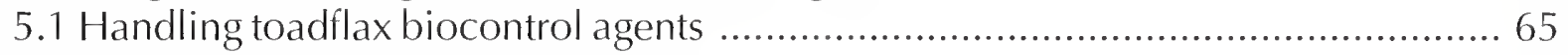

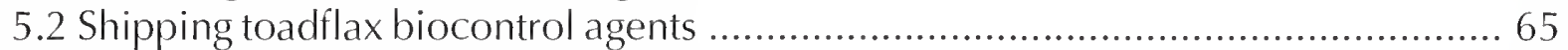

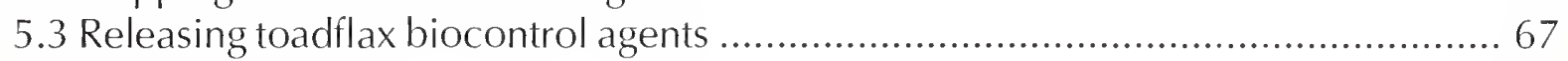

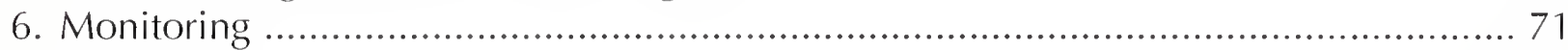

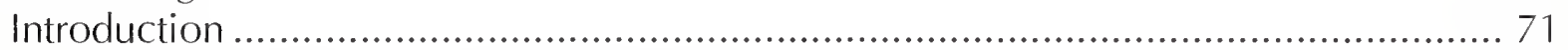

6.1 Determining your monitoring objectives …....................................................... 71

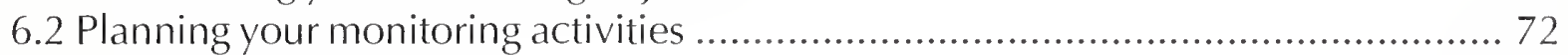

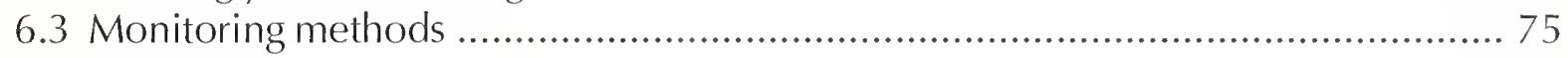


Selected References ..................................................................................87

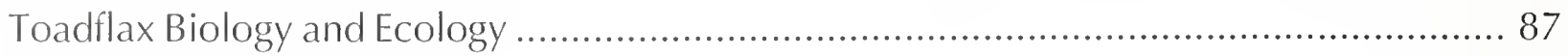

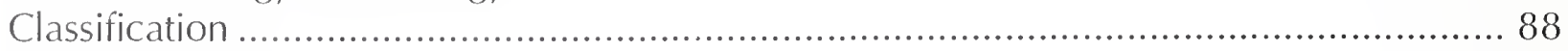

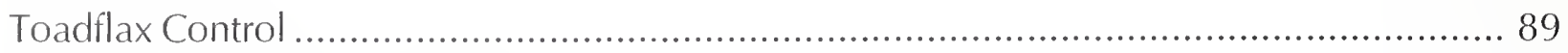

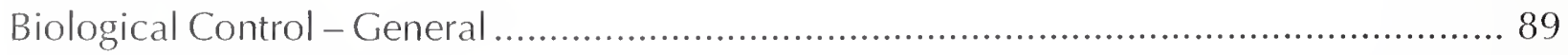

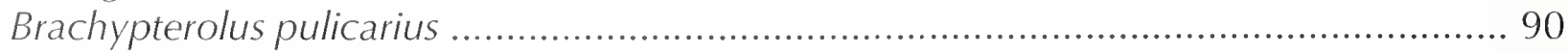

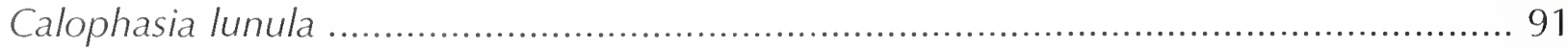

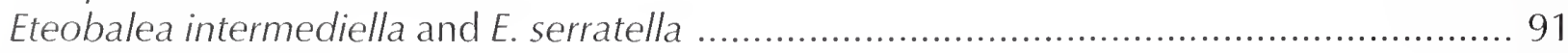

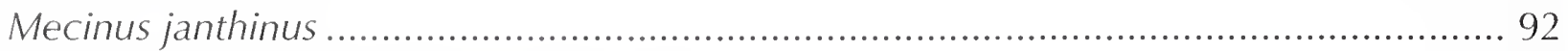

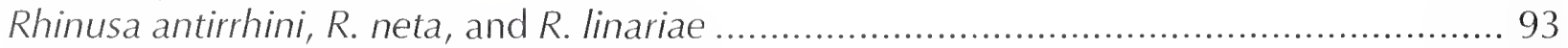

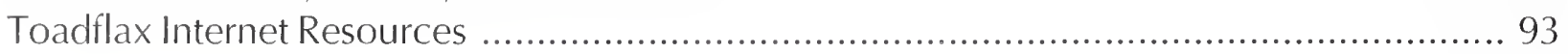

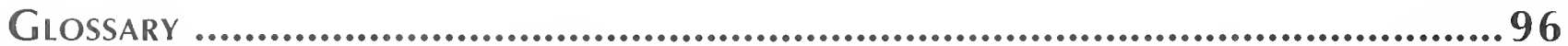

ACKNOWLEDGEMENTS ......................................................................................... 101

SOURCES OF FIGURES ....................................................................... 101

APPENDICES ......................................................................................... 103

Appendix A. Code of Best Practices for Biological Control of Weeds ................................. 105

Appendix B. Troubleshooting Guide: When Things Go Wrong .......................................... 106

Appendix C. Toadflax Biocontrol Release Form .............................................................. 108

Appendix D. Toadflax Monitoring Plan Questionnaire ..................................................... 110

Appendix E. Toadflax Biocontrol - Insect Monitoring Form ............................................. 111

Appendix F. Toadflax Biocontrol - Qualitative Monitoring Form ........................................ 113

Appendix G. Toadflax Biocontrol - Vegetation Monitoring Form ..................................... 114 


\section{Figures}

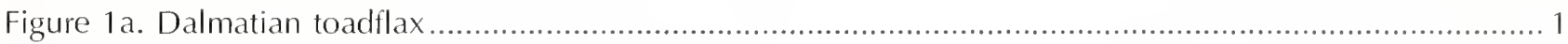

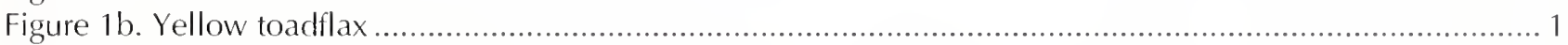

Figure 2. Distribution maps of a) yellow and b) Dalmatian toadflax in the United States and Canada ............... 2

Figure 3. Possible hybrid toadflax plant (center) between yellow (left) and Dalmatian toadflax (right) ............. 3

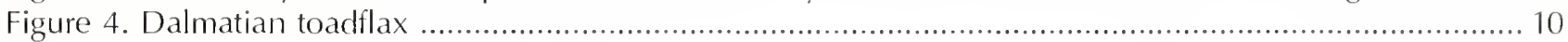

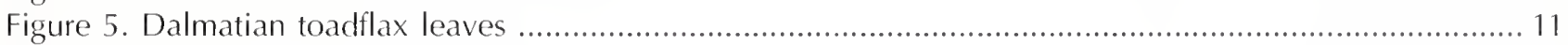

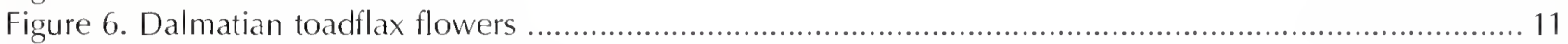

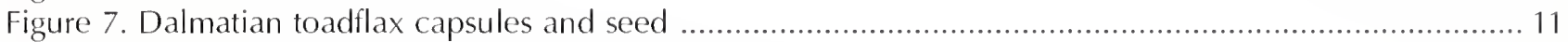

Figure 8. Dalmatian toadflax a) seedlings and b) young plant ............................................................ 12

Figure 9. Nonflowering, prostrate Dalmatian toadflax shoots produced mid- to late summer ........................ 12

Figure 10. Mature Dalmatian toadflax plant with vertical (flowering) and prostrate (nonflowering) stems ........ 12

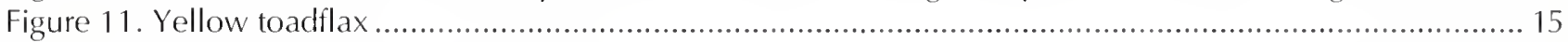

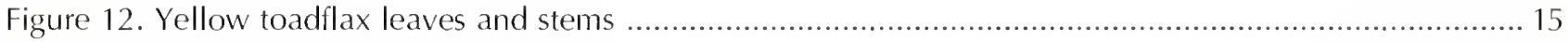

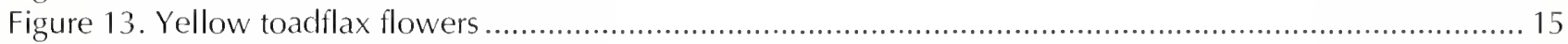

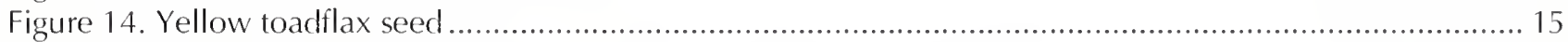

Figure 15. Dalmatian toadflax a) plant, b) flower, c) capsule, and d) seeds ........................................... 18

Figure 16. Yellow toadflax a) plant, b) flower, c) capsule, and d) seed .................................................... 19

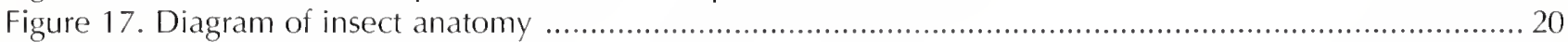

Figure 18. Insect life stages characteristic of complete metamorphosis ................................................ 21

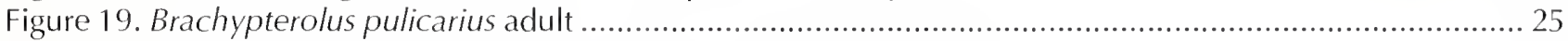

Figure 20. Brachypterolus pulicarius larva at the base of a toadflax flower ............................................... 25

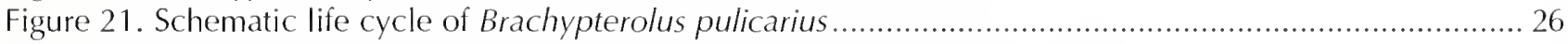

Figure 22. Brachypterolus pulicarius adults on a) yellow and b) Dalmatian toadflax ................................... 27

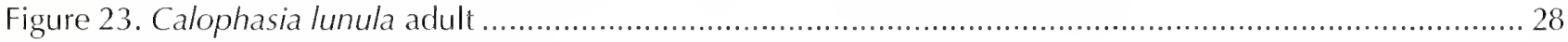

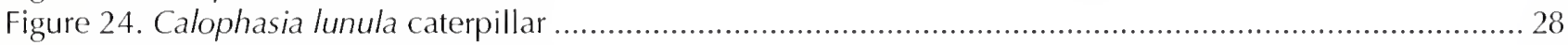

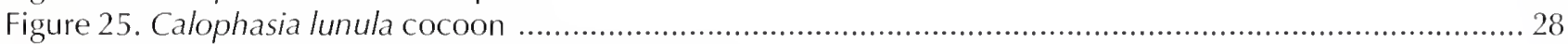

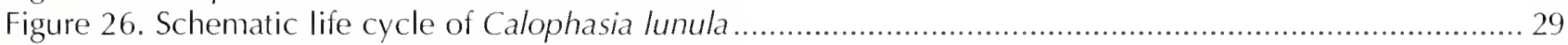

Figure 27. Defoliation of Dalmatian toadflax by Calophasia lunula ...................................................... 29

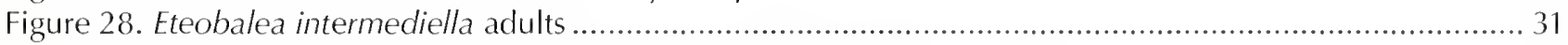

Figure 29. Egg surface texture of a) Eteobalea intermediella and b) E. serratella ....................................... 32

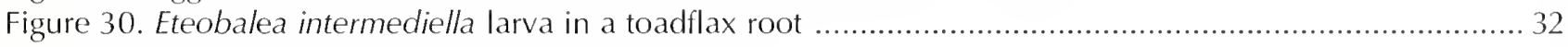

Figure 31a. Schematic life cycle of Eteobalea serratella ................................................................. 33

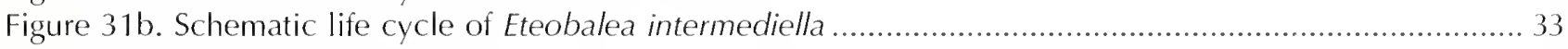

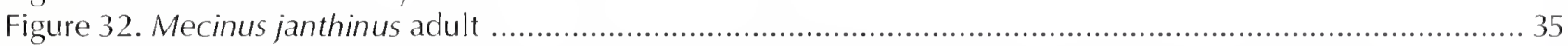

Figure 33. Spurs on the hind leg of Mecinus janthinus adult male (a) that are absent in the female (b) ............ 35

Figure 34. Foliage feeding damage by Mecinus janthinus adults ..................................................... 36

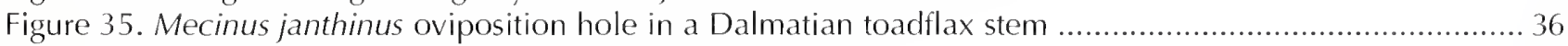

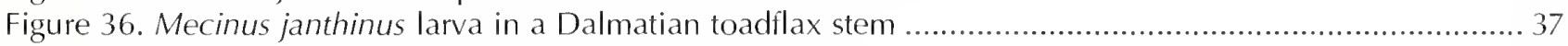

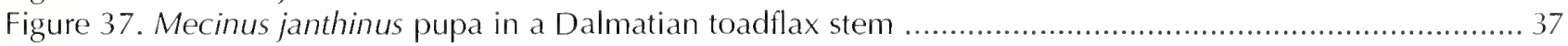

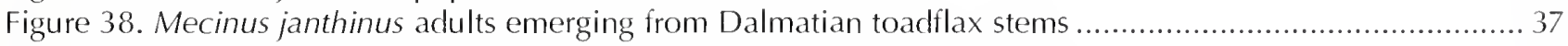

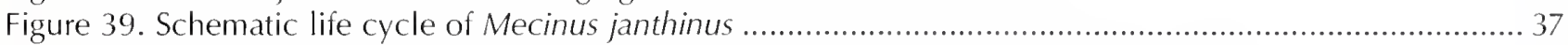

Figure 40. Numerous Mecinus janthinus adults and pupae inside Dalmatian toadflax stems ........................ 38

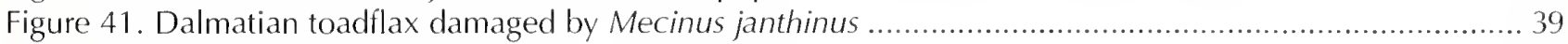

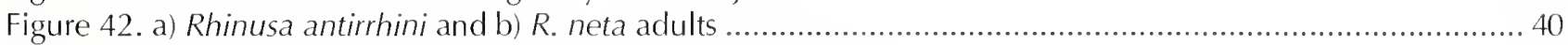

Figure 43. Rhinusa antirrhini larvae feeding inside yellow toadflax seed capsules .................................... 41

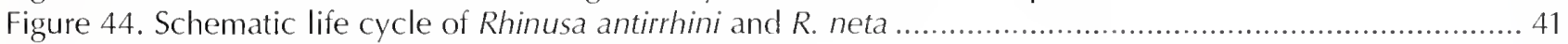

Figure 45. Swollen yellow toadflax seed capsules caused by Rhinusa antirrhini attack ................................ 42

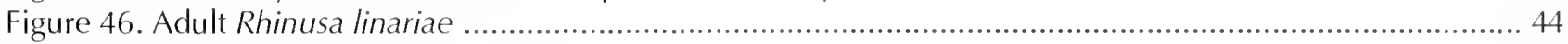

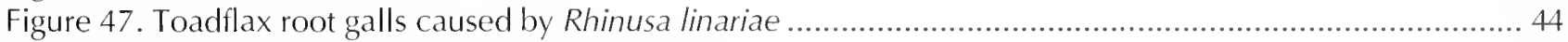

Figure 48. Schematic life cycle of Rhinusa linariae ............................................................................. 45

Figure 49. Generalized drawing of toadflax, indicating its biocontrol agents and the plant parts they attack ... 50 
Figure 50. Example of a suitable release site for most toadflax biocontrol agents ...................................... 56

Figure 51. Unwaxed paperboard containers used to transport and ship biocontrol agents ........................... 59

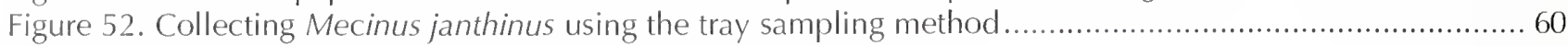

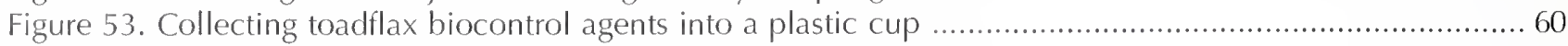

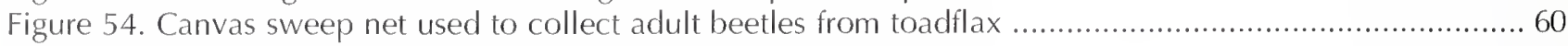

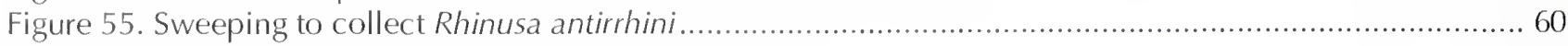

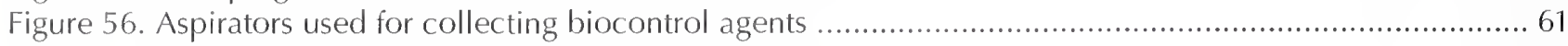

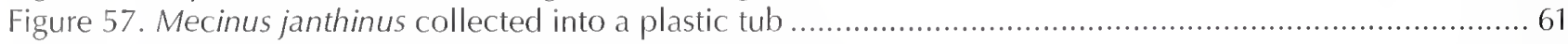

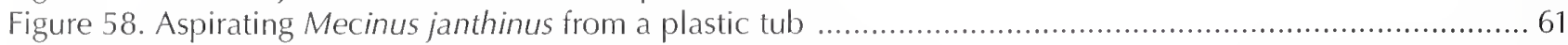

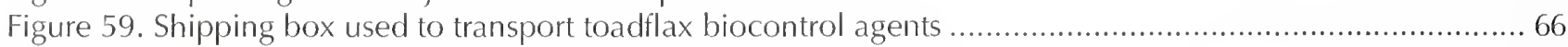

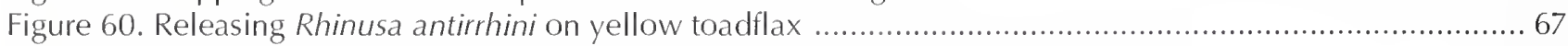

Figure 61. Characteristic foliage damage caused by adult Mecinus janthinus feeding ................................ 76

Figure 62. Defoliation of Dalmatian toadflax by Calophasia caterpillars ............................................... 76

Figure 63. Infestation of Dalmatian toadflax a) before and b) after release of Mecinus janthinus ................... 82

Figure 64. Metal quadrat used to define an area in which to measure vegetation ....................................... 83

Figure 65. Sample transect with survey markers used to permanently mark quadrat locations ...................... 84

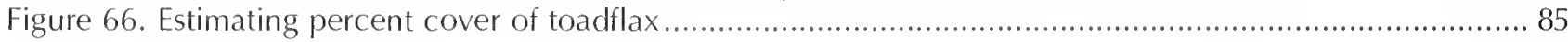

\section{TABLES}

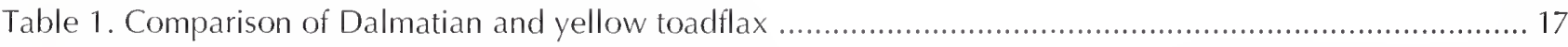

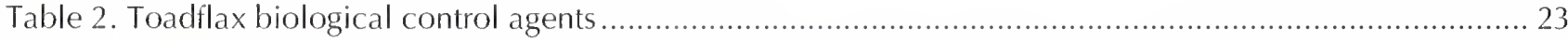

Table 3. Toadflax biocontrol agents established in North America and the species of toadflax they attack ....... 24

Table 4. Comparison of adult toadflax biological control agents and their damage ................................. 47-48

Table 5. Comparison of larvae and pupae of toadflax biocontrol agents and their damage ........................... 49

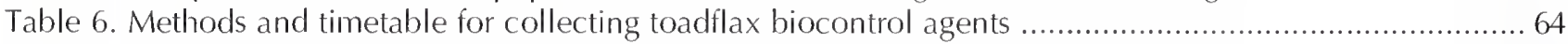

Table 7. Methods and timetable for releasing toadflax biocontrol agents ...............................................6. 69

Table 8. Methods and timetable to determine establishment of toadflax biocontrol agents ........................... 77

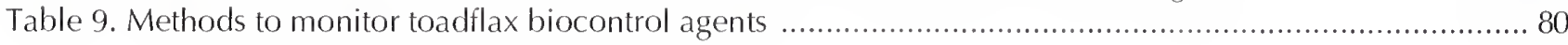

\section{Charts}

Chart 1. Predicted performance ratings for toadflax biocontrol agents 


\section{INTRODUCTION}

\section{Overview}

Dalmatian toadflax, Linaria dalmatica (L.) P. Mill. ssp. dalmatica (Fig. 1a), and yellow toadflax, Linaria vulgaris (L.) P. Mill. (Fig. 1b), are exotic [see Glossary] weeds of rangeland, forests and cropland. Although several species of weedy toadflax have been intentionally or accidentally introduced to North America, these two species are by far the most common and problematic for land managers. Both species are known to thrive particularly well in disturbed, open habitats, are most competitive, and can easily dominate native or desirable plant communities in areas characterized by dry summers.

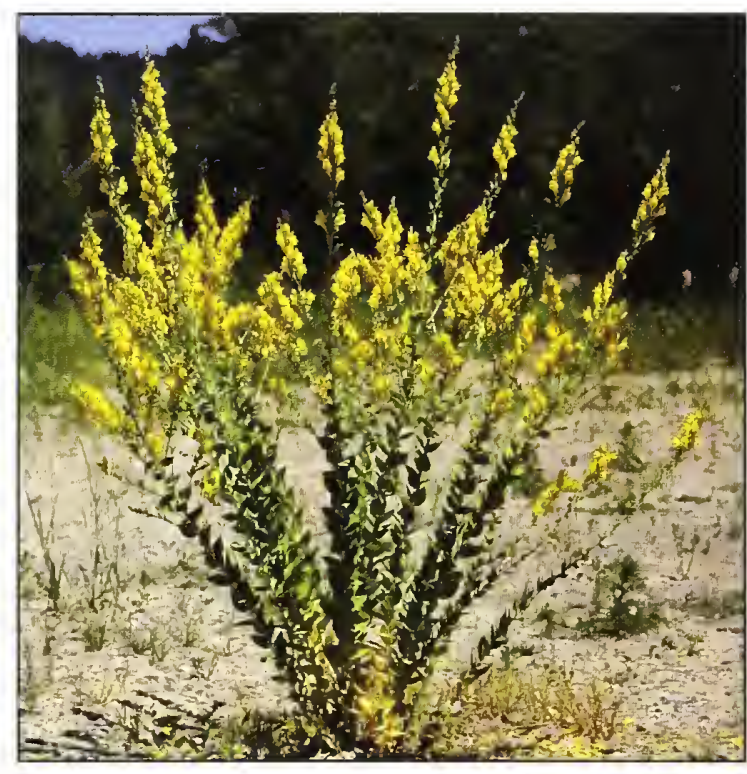

Figure 1a. Dalmatian toadflax. UGA1416001

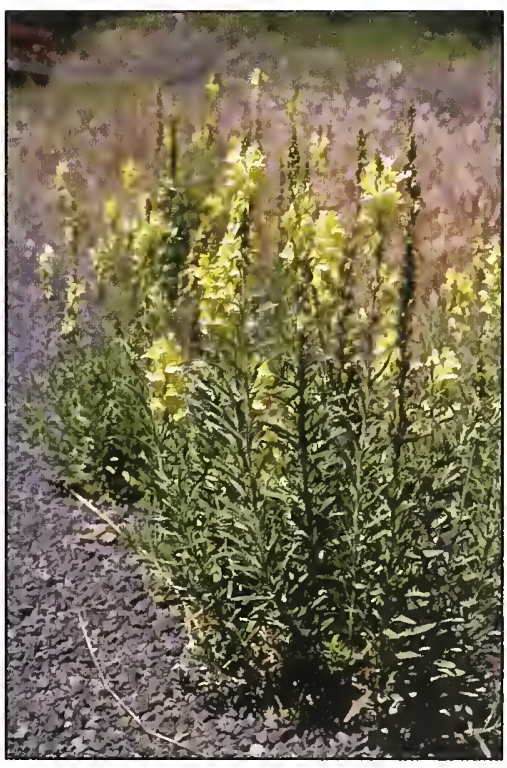

Figure 1b. Yellow toadflax. UGA1416002

Both Dalmatian and yellow toadflax are taprooted, short-lived perennial forbs that propagate by seeds and shoots growing from vegetative root buds. Toadflaxes belong to the genus Linaria in the figwort family, Scrophulariaceae. Both of these highly competitive and invasive plants were introduced to North America from Eurasia during the 1800 s as ornamental plants, and for use in fabric dye and folk remedies. 
Dalmatian toadflax is native to the region extending from central Europe to central Asia. Yellow toadflax originates from central Europe and the Mediterranean area. Their widespread distribution in North America is likely due to their use as ornamental plants. Exotic toadflaxes continue to be sold commercially in the United States, advertised as "butter and eggs," "wild snapdragon," "Jacob's ladder," or "yellow toadflax," although the sale of these two species is illegal in states where they are listed as noxious weeds.

These invasive toadflaxes are present in much of temperate North America. Yellow toadflax occurs in all continental states and provinces (Fig. 2a), and it has been legally designated a noxious weed in eight western states and the four western provinces. Dalmatian toadflax has a similar distribution, except that it is mostly absent in the southern and southeastern United States (Fig. 2b). Dalmatian toadflax is legally designated a noxious weed in nine western states and three western provinces (see http://invader.dbs.umt.edu, http://plants.usda.gov).

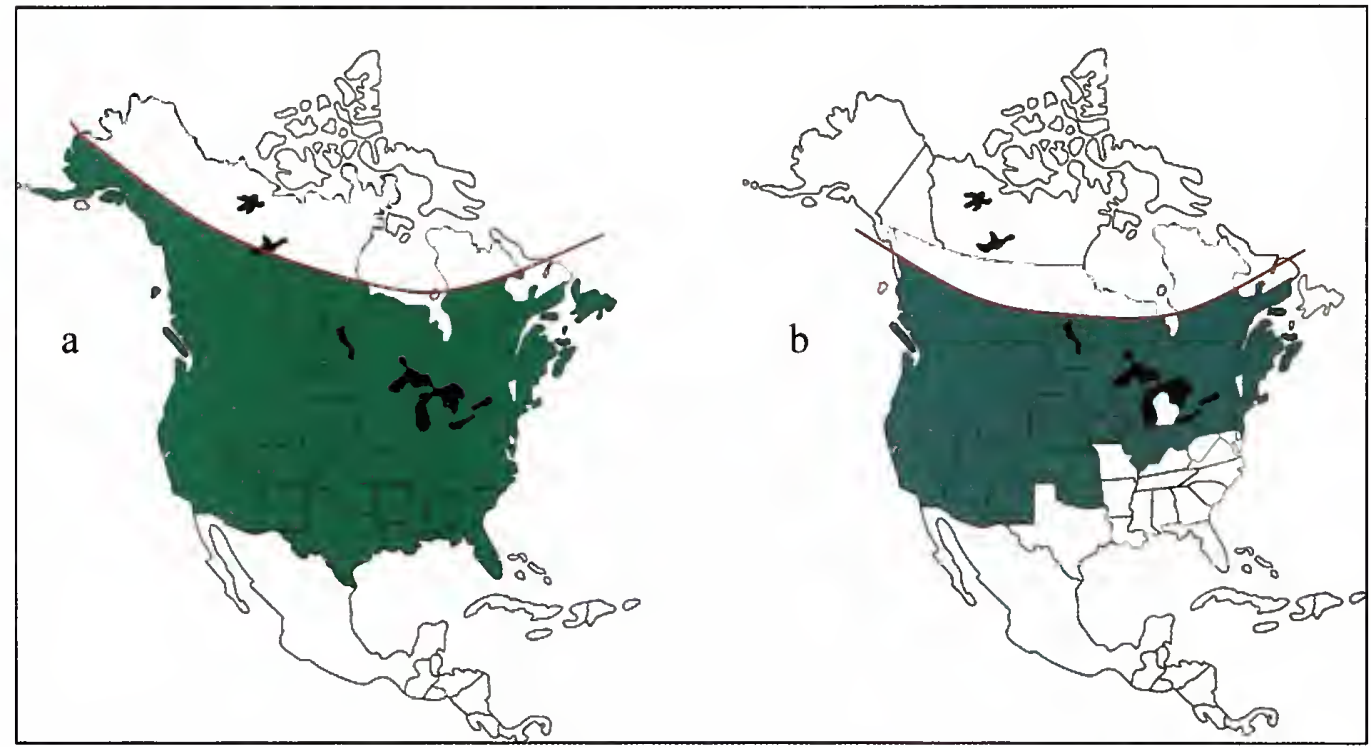

Figure 2. Distribution maps of a) yellow and b) Dalmatian toadflax in the United States and Canada. The colored area indicates infested lands.

Dalmatian toadflax is most commonly found on well-drained, relatively coarsetextured soils in disturbed and degraded sites, such as roadsides, abandoned lots and fields, waste areas, gravel pits, clearings, overgrazed or otherwise degraded rangelands, and along railroad tracks. Although yellow toadflax requires more moist and fertile conditions, it can invade sites at higher elevations (e.g., upland meadows), and affects cropland more than Dalmatian toadflax. Thus, it can be a serious management concern for both cultivated and uncultivated land. Toadflaxes contain compounds that can be toxic to cattle and horses (sheep and goats appear to be unaffected), although no cases of animal poisoning have been reported.

Successful management of the toadflaxes, with their robust root systems and abundant seed production, is a labor intensive process. Pulling small, individual plants is fairly easy, but pulling large plants can be more difficult and will probably leave behind 
viable root fragments that will eventually sprout new shoots. Hand-pulling small infestations can significantly deplete the seed bank, but only when repeated on an annual basis for a period of 5-6 years. Mowing flowering plants prevents seed production, but does not affect the roots, which can quickly respond by re-sprouting new shoots. Burning is not an appropriate control strategy because it does not kill the roots or buried seeds; moreover, burning can increase the susceptibility of a site to further toadflax invasion by removing competing vegetation. Plowing can be effective where yellow toadflax occurs in cropland, but it is usually not practical in the dry, gravelly sites preferred by Dalmatian toadflax. Plowing or discing requires repeated treatments to control new plants that sprout from cut root pieces. Selective herbicides, such as the phenoxy or sulfonylurea types, are effective against Dalmatian toadflax when used with a non-ionic surfactant, which enables the chemical to penetrate the waxy leaf surface. Yellow toadflax is thought to be more difficult to control with herbicides than Dalmatian toadflax.

The first biological control agents for exotic toadflaxes were unintentionally introduced into North America with infested toadflax plants from Europe. During the 1920s, a flower-feeding beetle, Brachypterolus pulicarius, was identified on yellow toadflax in New York state. Two seed-feeding weevils, Rhinusa antirrbini (formerly Gymnetron antirrbini) and $R$. neta (formerly G. netum) were discovered in Canada on yellow toadflax in the late 1950s. Five additional species have since been screened for safety and released in North America as classical biological control agents. In the early 1960s, biological control researchers released a defoliating moth, Calophasia lunula, in Canada, and later in the United States. During the 1990s, four additional biological control agents were approved for release in North America, including two root-boring moths, Eteobalea intermediella, and E. serratella, a root-galling weevil, Rhinusa linariae (formerly Gymnetron linariae), and a stem-mining weevil, Mecinus janthinus.

Dalmatian and yellow toadflax growing throughout North America are highly variable in shape, size, and sometimes color. Some plants may resemble a narrow-leaved form of Dalmatian toadflax (Fig. 3, center), believed by some plant taxonomists to be a bybrid between Dalmatian and

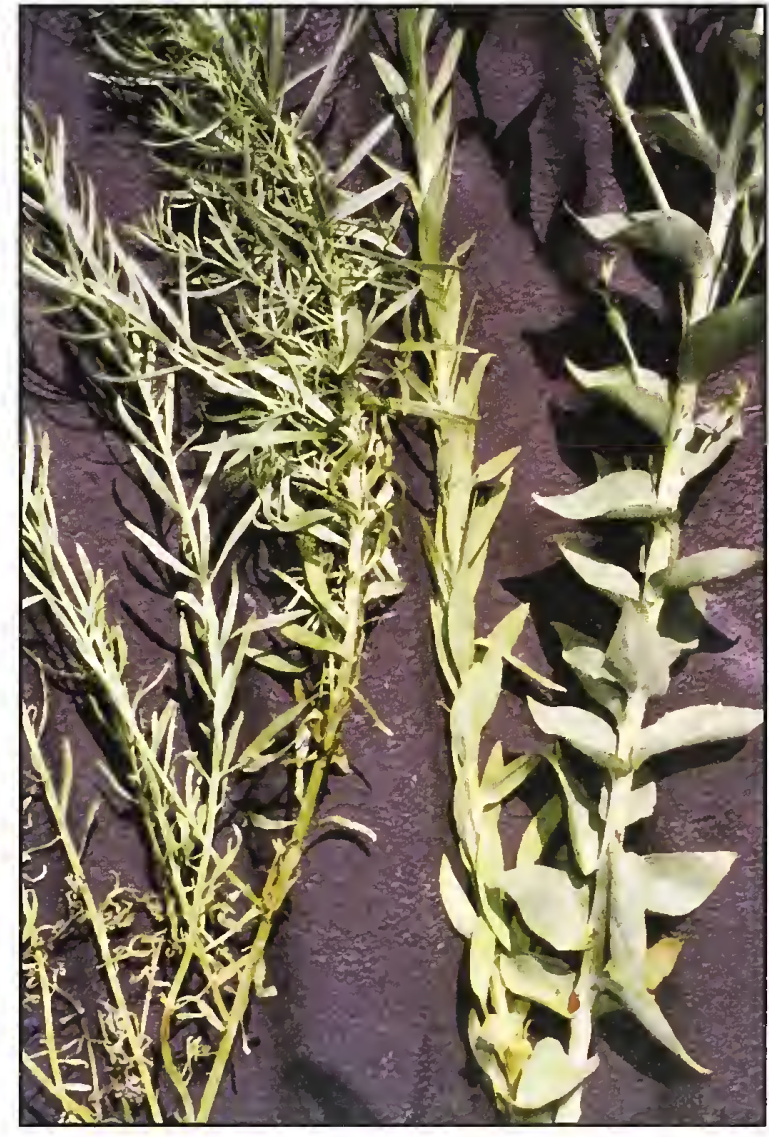

Figure 3. Possible hybrid toadflax plant (center) between yellow toadflax (left) and Dalmatian toadflax (right). UGA1416003 
yellow toadflax. Other taxonomists consider the narrow-leaved form of Dalmatian toadflax to be a completely separate, invasive European species, called broomleaf toadflax, Linaria genistifolia. For the purpose of this manual, we follow the nomenclature used by the USDA - Natural Resources Conservation Service (NRCS) (see bttp://plants.usda.gov).

Clarification of these taxonomic questions increases the odds of attaining success with a toadflax biocontrol program because the efficacy of biocontrol agents is known to vary significantly among the different species and intermediate forms of toadflax. For example, one biotype of the seed-feeding weevil attacks yellow toadflax and the narrow-leaved form of Dalmatian toadflax, but does not attack Dalmatian toadflax. High genetic variability within the invasive toadflaxes not only confounds biocontrol efforts, but also enables these species to thrive in a wide range of habitat types and climatic zones.

\section{Biological Control of Weeds}

Most weeds in North America are not native species; they arrived over the past 400 or more years with immigrants and commerce (particularly horticultural) from other continents, especially Europe. Some plants were intentionally brought for medicinal purposes or to adorn gardens, while others arrived as stowaways in ship ballast or clinging to livestock, clothing, and other goods. These immigrant plants are generally introduced without their natural enemies, a complex of plant-eating organisms that attack them and help to regulate their populations in their native land. The absence of natural enemies enables many introduced plant species to be strong competitors where they are introduced and causes some to become invasive in new areas of introduction.

Biological control of weeds is the deliberate use of natural enemies to limit the distribution and abundance of a target weed. Classical biological control uses hostspecific natural enemies from the target weed's native range (the terms "biological control" or "biocontrol" used throughout this manual refer to classical biological control). Natural enemies (also referred to as biocontrol agents) can kill or severely damage plants by consuming or injuring seeds, roots, foliage, or stems. Damage caused by natural enemies may limit the reproduction of the weed, diminish the weed's ability to compete with other plants, or facilitate secondary infection from pathogens. By reuniting invasive plants with their natural enemies, classical biological control restores at least a part of the ecological balance that limits the competitive ability of a target weed species in its native range. Natural enemies used in classical biological control of weeds are usually insects and mites, and sometimes nematodes, fungi, and even vertebrates (e.g., fish used for control of aquatic weeds). Beetles, flies, and moths are among the most commonly used insects.

Classical biological control of weeds has a number of advantages. Biocontrol is selective, meaning that it is targeted to a specific weed or closely related group of weeds. Biological control is also sustainable, providing long-term control while 
reducing supply and labor costs associated with repeated mechanical or chemical treatments. Because biocontrol agents are self-perpetuating, the long-term cost: benefit ratio associated with classical biological control is more favorable than that of other control methods. The major disadvantage of biocontrol of weeds is the uncertainty about whether approved agents will be effective in controlling the target weed. Another concern is the risk of unintended, adverse impacts on native plant species and other organisms (nontarget effects). Because introductions of biocontrol agents into the environment are irreversible, agents must be carefully selected and extensively studied before being approved for release to ensure that they will not damage valued plants.

The most important precondition for an insect to be used as a biocontrol agent is that it will die without the target weed. To be considered for release in the United States and Canada, insect biological control agents must eat and develop only on the target plant, or, in some cases, on only a few closely related plant species. This is known as host specificity, and is the ecological cornerstone of classical biological control of weeds. Potential biocontrol agents often undergo more than five years of rigorous testing to ensure that host specificity requirements are met. These studies are important in order to 1) introduce effective biocontrol agents and 2) protect nontarget plant species.

The life cycle of an approved biocontrol agent is well-studied to ensure that it will be closely matched, synchronized, with that of its host plant. For example, properly synchronized foliage-feeding insects are in the feeding stage when the weed is actively growing and most nutritious, and root-feeding insects are in the feeding stage when root resources provide optimal food or shelter.

Researchers and practitioners in classical biological control of weeds adhere to a set of professional standards, known as the "Code of Best Practices for Classical Biological Control of Weeds" (see Appendix A). The code is a set of agreed-upon principles that are followed to ensure that classical biocontrol of weeds programs are justified and that only safe and approved agents are released.

The United States Department of Agriculture-Animal and Plant Health Inspection Service-Plant Protection and Quarantine (USDA-APHIS-PPQ) is the federal government agency responsible for authorizing the importation of biocontrol agents into quarantine facilities for continued study. The Technical Advisory Group for Biological Control Agents of Weeds (TAG) is an expert committee representing federal land management and environmental organizations with representatives from Canada and Mexico. TAG reviews all petitions to import new biocontrol agents into North America, and makes recommendations to USDA-APHIS-PPQ about whether to grant a permit allowing the importation of a candidate biocontrol agent. In addition, a committee of experts in Canada also reviews petitions submitted to APHIS.

Approval for final field release of biocontrol agents is granted by the individual state. Laws and regulations are in place to minimize the risks to native plants and animals that are associated with the introduction of exotic organisms to manage weeds. Weed 
biocontrol researchers work closely with USDA-APHIS-PPQ and TAG to ensure they have done all they can to preserve the environmental safety of weed biocontrol programs. For more information, refer to the APHIS-PPQ website at bttp:// www.aphis.usda.gov/ppq.

Although weed biocontrol is an effective and important weed management tool, it does not always work, and in most cases, it will not eradicate the target weed. The goal of a classical biological control of weeds program is to reduce the abundance of the target weed to levels where it no longer degrades the plant community and to restore biodiversity and the economic value of the land. In general, classical biocontrol programs reduce a weed's ability to compete with native plants. Often, biological control can be integrated with other methods of weed control: for example, chemical or cultural control and prescribed livestock grazing. For more information on classical biological control of weeds we recommend reading the literature listed in the Selected References section of this manual.

\section{About This Manual}

This manual provides background information on the biology and ecology of Dalmatian and yellow toadflax and on each of the insects that were accidentally introduced or approved for biological control of toadflax. It also provides guidelines that explain how to establish and manage a toadflax biocontrol program. The manual is divided into the following chapters:

Chapter 1 provides a detailed description of Dalmatian and yellow toadflax, including their scientific names, description of the leaves, stems, flowers, seeds; and descriptions of their biology and ecology. Photographs and drawings are provided in illustration.

Chapter 2 describes the eight toadflax biocontrol agents: three moths and five beetles. Information on biocontrol agent identification, life cycle, biology, and ecology is provided. This chapter is particularly useful for identifying biocontrol agents in the field.

Chapter 3 includes detailed information and guidelines on how to plan, implement, and monitor an effective toadflax biocontrol program incorporating one or more of the eight biocontrol agents. Included are descriptions and methods for:

- Planning a toadflax biocontrol program

- Selecting and preparing toadflax biocontrol release sites

- Deciding what toadflax biocontrol agent(s) to release

- Collecting, handling, transporting, shipping, and releasing toadflax biocontrol agents

- Monitoring toadflax biocontrol agents and their impacts on toadflax and other vegetation 
Glossary defines technical terms essential to communicating specifics about toadflax biological control. Words in bold italic in text are defined in the glossary.

Selected References are provided from the large body of literature on toadflax biology, ecology, and biological control. Also included is a selected list of Internet sites that provide a wealth of practical information.

Appendices provides the Code of Best Practices for Classical Biological Control of Weeds, a troubleshooting guide, examples of insect release and monitoring forms, and vegetation monitoring forms (these forms may be reproduced for use as needed).

These are, in order of appearance:

Appendix A: Code of Best Practices for Classical Biological Control of Weeds Appendix B: Troubleshooting Guide: When Things Go Wrong

Appendix C: Toadflax Biocontrol Release Form

Appendix D: Toadflax Monitoring Plan Questionnaire

Appendix E: Toadflax Biocontrol - Insect Monitoring form

Appendix F: Toadflax Biocontrol - Qualitative Monitoring form

Appendix G: Toadflax Biocontrol - Vegetation Monitoring form 


\section{CHAPTER 1}

\section{Getting to Know the Toadflaxes}

Many ornamental plants were brought to North America by early European immigrants who wanted to adorn their gardens with familiar plants from home. Both Dalmatian and yellow toadflax were favorites, imported and planted by settlers beginning as early as the $18^{\text {th }}$ century. The toadflaxes are among the best examples of ornamental plants that escaped cultivation to become invasive and noxious weeds.

According to folklore, the plant was called toadflax because toads sometimes sheltered themselves among toadflax branches, and the mouth of the flower resembles the wide mouth of a toad. The genus name, Linaria, is derived from linum (flax), named for its resemblance to a flax plant before flowering. The plant is also known as flaxweed. The combination of light yellow and orange in yellow toadflax flowers has earned it the common names 'butter and eggs' and 'eggs and bacon'.

Other related species in the figwort family are popular ornamental plants, such as garden snapdragon (Antirrhinum majus), speedwell (Veronica spp.), penstemon (Penstemon spp.), foxglove (Digitalis spp.), and mullein (Verbascum spp.).

There are about 13 species of toadflax in the United States and Canada. Historically, there were three native Linaria species or varieties in North America, L. canadensis (Canada toadflax), L. canadensis var. texanus (blue toadflax), and L. texanus (Texas toadflax). However, in 1988 all species were reclassified and moved into the genus Nuttallanthus. Therefore, following current taxonomy, there are no native Linaria species in the United States or Canada, and the remaining 11 species are all exotic. For a list of other Linaria species in the United States, visit the website of the USDA - Natural Resources Conservation Service (NRCS) (see http://plants.usda.gov).

The following sections describe Dalmatian and yellow toadflax in greater detail. 


\section{Dalmatian Toadflax}

Scientific name: Linaria dalmatica (L.) P. Mill. ssp. dalmatica

Synonym: Linaria genistifolia (P.) Mill. ssp. dalmatica (see Note on page 13)

Common names: Dalmatian toadflax, broad-leaved toadflax

Family: Scrophulariaceae (Figwort)

Description: Dalmatian toadflax (Fig. 4) is an erect, perennial herb commonly found in semi-arid areas on coarse-textured, gravelly soils. It is usually associated with sparsely vegetated areas, such as roadsides, abandoned or unmanaged land, gravel pits, and disturbed pastures and rangelands. It was brought to North America in the early 1900s for ornamental and medicinal purposes.

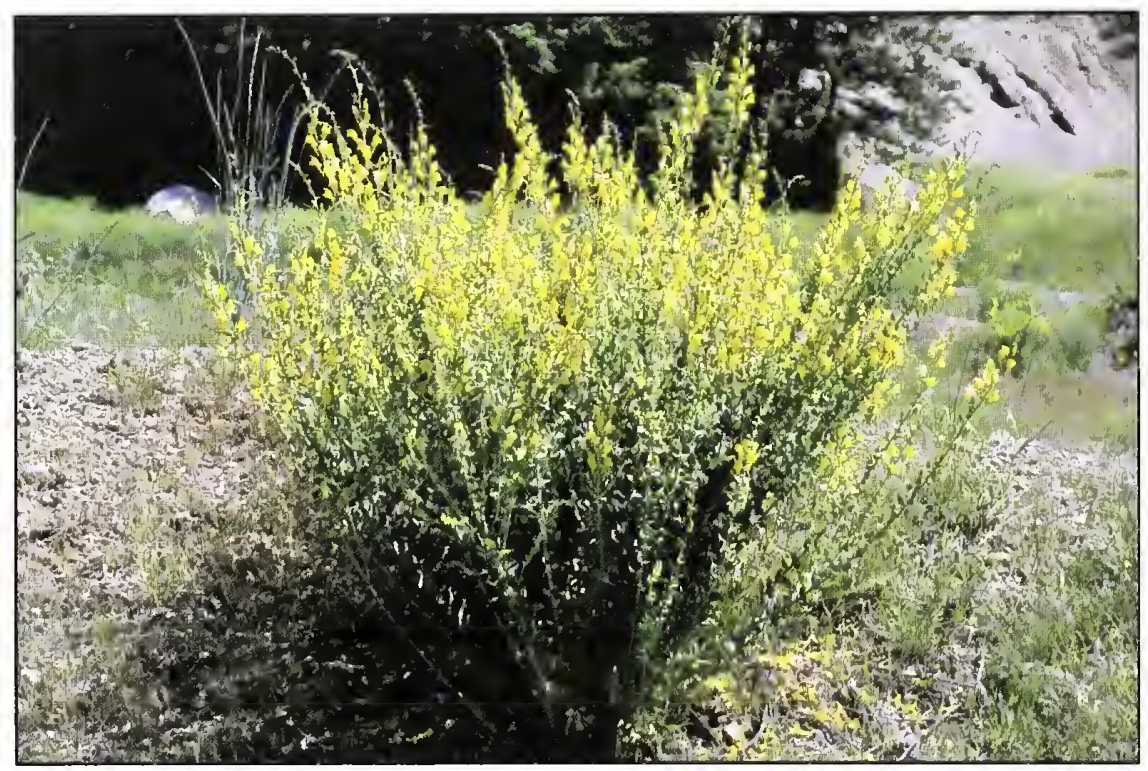

Figure 4. Dalmatian toadflax. UGA1416004

Leaves: Dalmatian toadflax leaves (Fig. 5) are broad, alternate, 1 to 2 in $(2$ to $5 \mathrm{~cm}$ ) long, and almost as wide. The lower leaves are heart-shaped and clasp the stem; upper leaves are smaller and ovate-lanceolate shaped. Leaves are usually bluishgreen and have a distinct waxy appearance.

Stems: A Dalmatian toadflax plant can produce one to 25 stiff, vertical, leafy stems that are thick-walled, fibrous, and waxy in appearance. Mature Dalmatian toadflax plants grow 2 to $5 \mathrm{ft}(0.8$ to $1.5 \mathrm{~m})$ tall. Nonflowering, prostrate stems are produced in the summer and usually persist until the following growing season.

Flowers: The Dalmatian toadflax flower is a bright yellow, two-lipped, snapdragonlike blossom with an orange throat and a long spur (Fig. 6). Flowers are borne on short stalks that arise in the axils of upper stem leaves, and are 0.8 to 1.6 in (2 to 4 $\mathrm{cm})$ long. 
Seeds: Dalmatian toadflax produces egg-shaped to nearly round, upright seed capsules that are 0.2 to 0.4 in $(0.4$ to $1.0 \mathrm{~cm})$ long and 0.2 to 0.3 in $(0.4$ to $0.9 \mathrm{~cm})$ wide (Fig. 7). Each capsule contains 60 to 300 seeds. Seeds are sharply triangular, slightly winged, and approximately 0.04 in $(0.1 \mathrm{~cm})$ long.

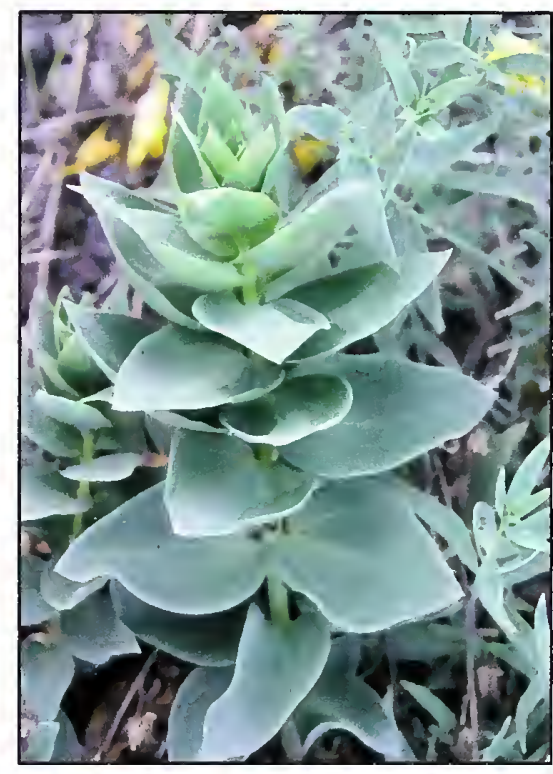

Figure 5. Dalmatian toadflax leaves. UGA1416005

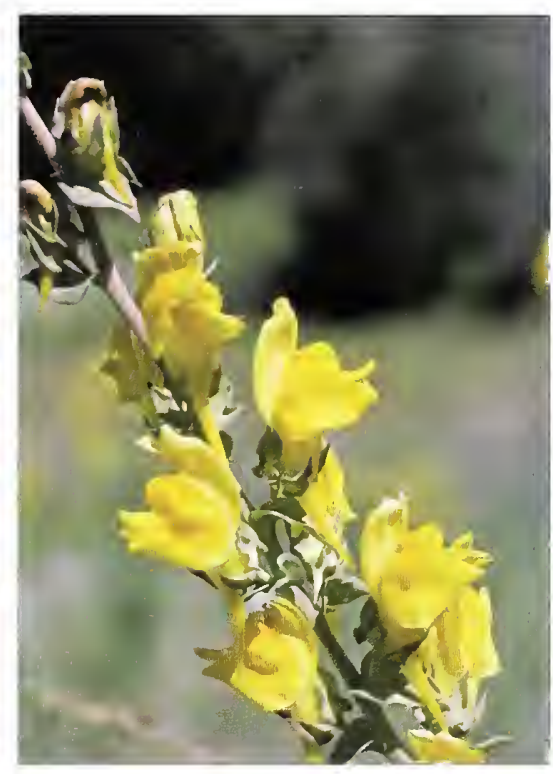

Figure 6. Dalmatian toadflax flowers. UGA1416006

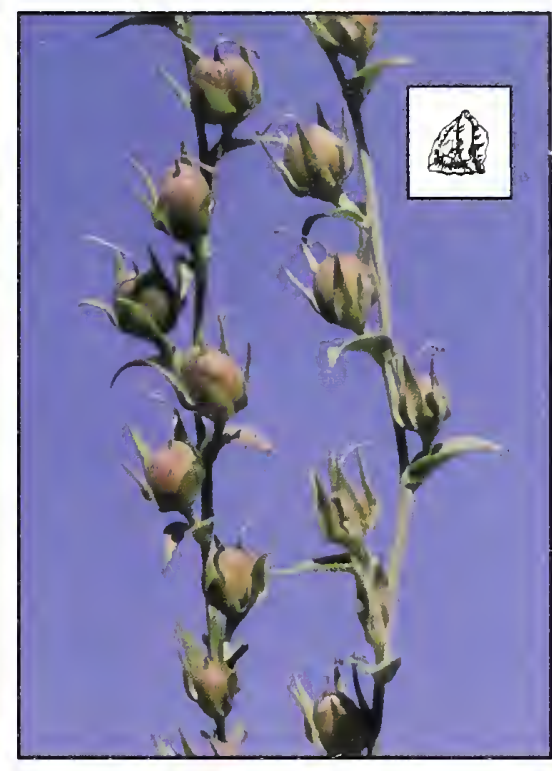

Figure 7. Dalmatian toadflax capsules and seed. UGAT416007

\section{Biology and Ecology}

Seeds of Dalmatian toadflax germinate in the fall or spring. Seedlings (Fig. 8a) grow quickly, establishing a deep, 20 in $(51 \mathrm{~cm})$ long taproot within eight weeks and producing two to five vertical flowering, and prostrate, nonflowering stems in the first season (Fig. 8b). The prostrate stems (Fig. 9) grow in summer and remain green throughout the winter, especially under snow cover. In the second year and subsequent years, there can be up to 25 flowering stems and up to 40 nonflowering stems arranged a loose rosette at the base of the plant (Fig. 10). Seasonal growth of stems can begin as early as February in warm areas, or as late as April in cooler, northern areas. Flowering occurs from May to October. Dalmatian toadflax is self-incompatible and must receive pollen from another toadflax plant in order to set viable seed. Flowers are cross-pollinated by bumblebees and other large bees, and seeds are produced from late June to December. A mature plant can produce up to 500,000 seeds, which are gradually released from the seed capsules through the fall and winter. Seeds can also be dispersed when stems break off and are blown around by the wind. Seed germination rates can be high, but seeds also can remain dormant in the soil for up to 10 years. 


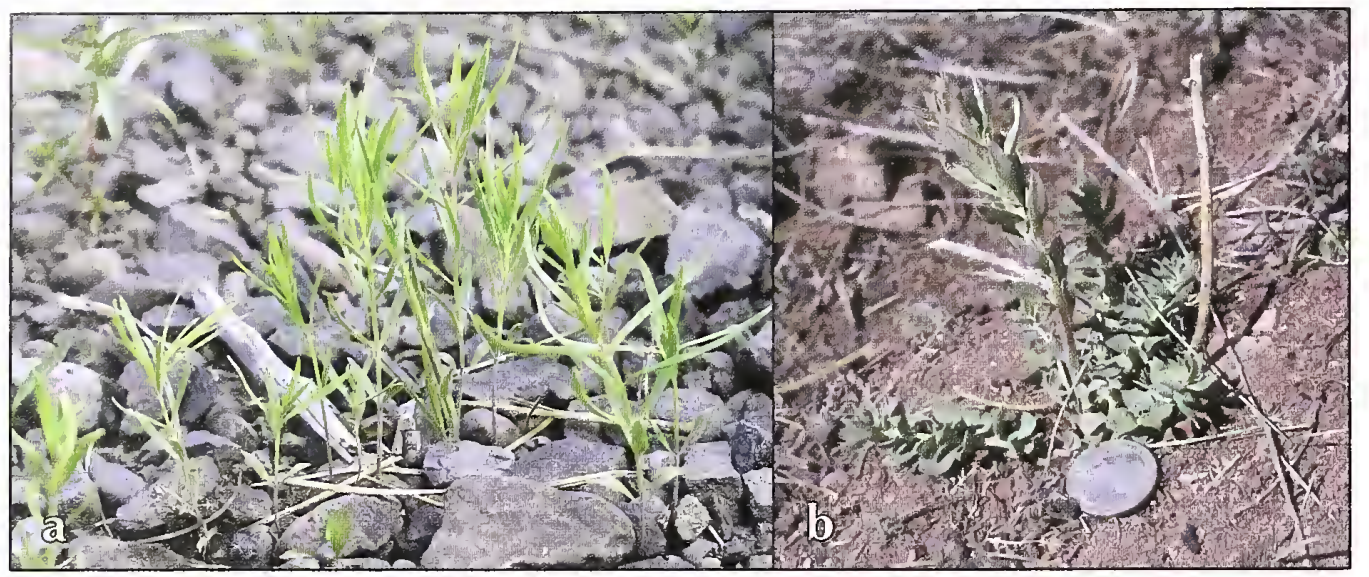

Figure 8. Dalmatian toadflax a) seedlings and b) young plant. UGA1416008

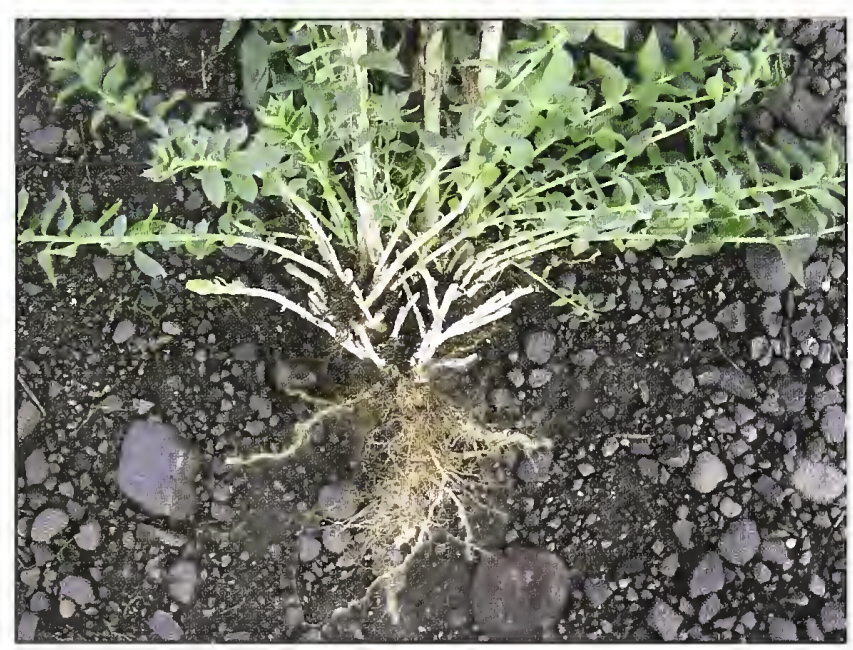

Figure 9. Nonflowering, prostrate Dalmatian toadflax shoots produced mid- to late summer. UGA1416009

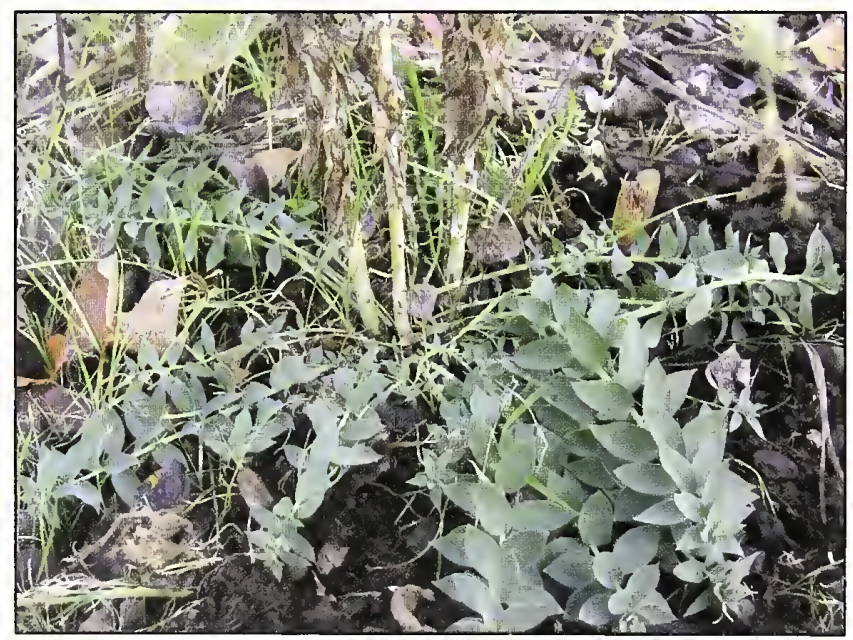

Figure 10. Mature Dalmatian toadflax plant with vertical (flowering) and prostrate (nonflowering) stems. UGA1416010 
In addition to seeds, Dalmatian toadflax reproduces vegetatively by stems that develop from adventitious buds on primary and creeping lateral roots. Vegetative reproduction from root buds can occur as early as two to three weeks after germination. Over time, these shoots form roots and eventually become independent plants. New shoots also can arise from severed root fragments as short as 0.4 in $(1 \mathrm{~cm})$ in length.

Once established, high seed production and vegetative propagation enables Dalmatian toadflax to spread rapidly and to dominate and persist at a site. The large, contorted, deeply penetrating taproots and vigorous, early season growth enables Dalmatian toadflax to efficiently capture water and nutrients, outcompeting other plants in coarse, nutrient-poor soils. Lateral roots can grow up to $10 \mathrm{ft}(3 \mathrm{~m})$ long, solidly anchoring the plant against anyone or anything attempting to dislodge it. Dalmatian toadflax roots have a lifespan of about four years.

Stems of Dalmatian toadflax contain an acrid, bitter-tasting liquid that makes the plant unpalatable to grazing animals. These compounds, called glycosides, are considered toxic to livestock, but reports of animal poisonings have not been reported.

Note: Dalmatian toadflax can sometimes be found in the literature referred to botanically as L. genistifolia or L. genistifolia ssp. dalmatica. This is because the taxonomy of Dalmatian toadflax and its various biotypes or hybrids are not clearly understood. Although it is difficult to assign a definitive name to invasive Dalmatian toadflax, it is important to understand that, because hybrids occur, toadflax exists in a variety of forms. 


\section{Yellow TOAdfLAX}

Scientific Name: Linaria vulgaris P. Mill.

Common Names: Yellow toadflax, common toadflax, wild snapdragon, perennial snapdragon, flaxweed, butter and eggs, eggs and bacon, Jacob's-ladder, rabbit-flower.

Family: Scrophulariaceae (Figwort)

Description: Yellow toadflax (Fig. 11) is an erect, herbaceous, short-lived perennial weed that invades and persists in chronically disturbed sites along roadsides and railways, as well as in cultivated fields, pastures and rangeland. Yellow toadflax is a common weed across North America, preferring sites with well-drained, coarse soils in disturbed, open habitats. This native of southeastern Europe and southwestern Asia was intentionally introduced to North America as early as the mid1700 s for horticultural and medicinal purposes.

Leaves: Yellow toadflax leaves are 1 to 2 in $(2.5$ to $5 \mathrm{~cm})$ long, linear, and pointed with a narrow, tapering base (Fig. 12). Older leaves have a single vein visible on the underside. Leaves are pale green with a silvery tinge, and are arranged alternately on the stem.

Stems: Yellow toadflax stems range from less than $1 \mathrm{ft}(31 \mathrm{~cm})$ to nearly $3 \mathrm{ft}(0.9 \mathrm{~m})$ tall, generally unbranched, or at most, sparsely branched. A single yellow toadflax plant can produce several woody stems. The woody stems usually have a reddish color at the base, becoming more slender, succulent, and greener toward the growing tip.

Flowers: Yellow toadflax flowers are pale yellow, two-lipped, spurred, snapdragonlike blossoms that are 0.8 to 1.6 in $(2$ to $4 \mathrm{~cm})$ long. Unlike Dalmatian toadflax flowers, the bearded throat of yellow toadflax flowers is bright orange (Fig. 13). Flowers are clustered at the top of the stem in groups of six to 30 .

Seeds: Seeds are produced in an upright, oval, two-celled seed capsule. Each stem can produce up to 30 capsules, with each capsule yielding up to 250 seeds. The seeds are small, lightweight, winged discs, 0.06 in $(0.02 \mathrm{~mm})$ in diameter (Fig. 14). A large, mature yellow toadflax plant can produce over 7,500 seeds per stem and between 15,000 and 20,000 seeds per plant. 


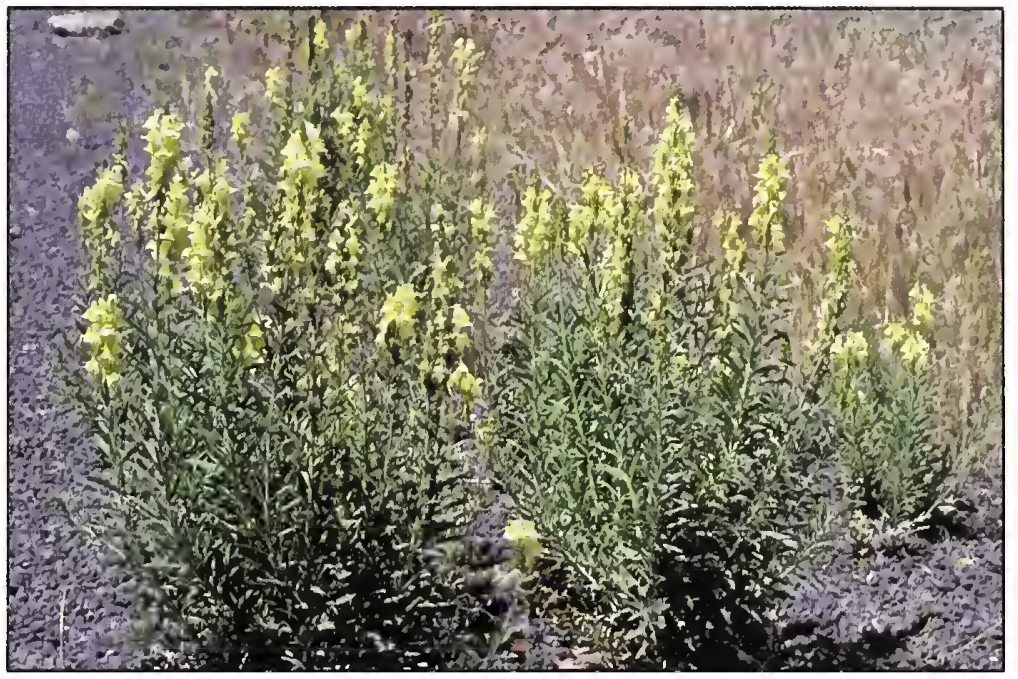

Figure 11. Yellow toadflax. UGA1416011

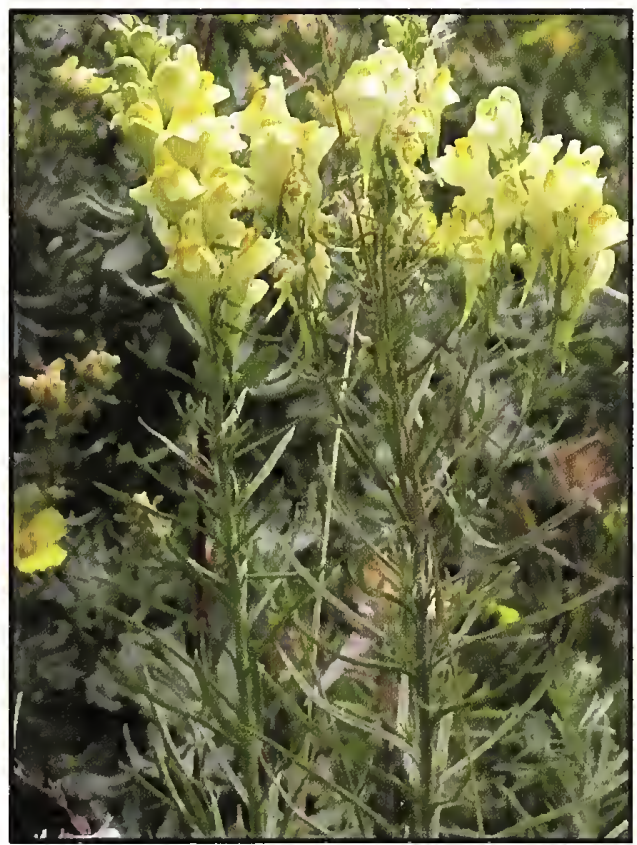

Figure 12. Yellow toadflax leaves and stems, UGA1416012

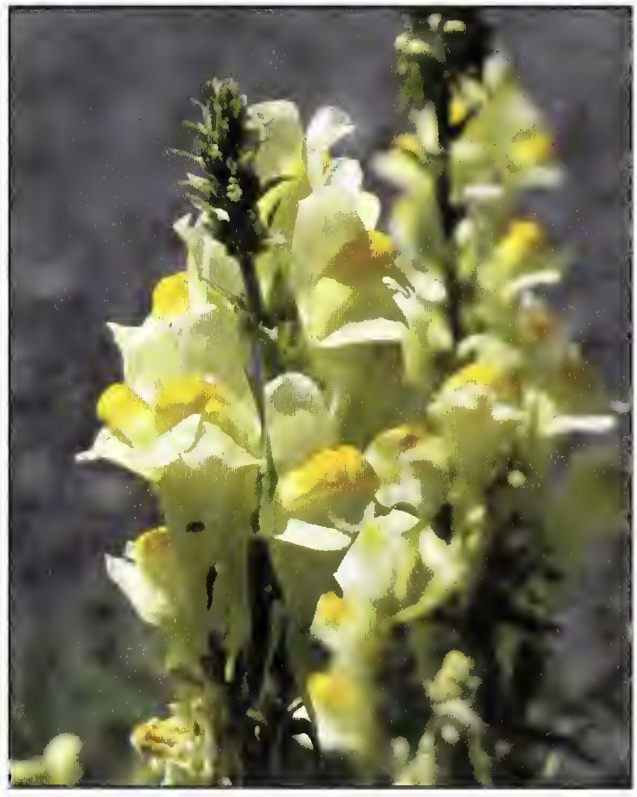

Figure 13. Yellow toadflax flowers. UGA1416013

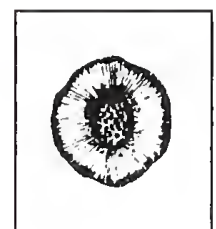

Figure 14. Yellow toadflax seed. 


\section{Biology and Ecology}

Viability of yellow toadflax seeds is low, and spring germination rates of less than 10 percent are typical. Some viable seeds can remain dormant in the soil for several years. Seedlings are weak competitors, and mortality rates can be high during drought conditions.

Established seedlings produce a taproot within two to three weeks after germination, and soon after begin to produce creeping, horizontal roots. Yellow toadflax is deeprooted; thus, it competes well for water and nutrients. Its taproot can penetrate $3.3 \mathrm{ft}$ $(1.2 \mathrm{~m})$ into the soil, and lateral roots can extend greater than $3 \mathrm{ft}(0.9 \mathrm{~m})$ from the plant. These spreading roots can produce up to 100 shoots during the first summer, creating crowded patches of yellow toadflax. Yellow toadflax roots have a lifespan of about four years.

Young shoots grow rapidly, and flower from late June until late autumn. Yellow toadflax flowers are cross-pollinated by bumble bees and other large bees; in areas where bees are sparse, limited pollination may result in low seed production. Yellow toadflax seeds are released from the dry seed capsules beginning in August and continuing through winter. Seed capsules maturing late in the season (November) contain more viable seeds than those maturing earlier in the season (September).

Aboveground parts of yellow toadflax plants are winter-killed, but protected buds at the soil surface and buds on creeping roots produce actively growing shoots the following spring. While most new infestations are probably started by seeds, spread of established infestations is mostly vegetative from shoots sprouting from the large network of creeping roots. Severely damaged plants, such as those killed by wildfire, can quickly regenerate from the stout, soil-protected roots. This enables yellow toadflax to become a dominant member of post-fire plant communities. In cropland, severed root fragments can spread across a field during cultivation, giving rise to new toadflax patches. 


\section{Summary}

Dalmatian and yellow toadflax share a number of characteristics and yet are quite different. The following table highlights their features.

Table 1. Comparison of Dalmatian and yellow toadflax.

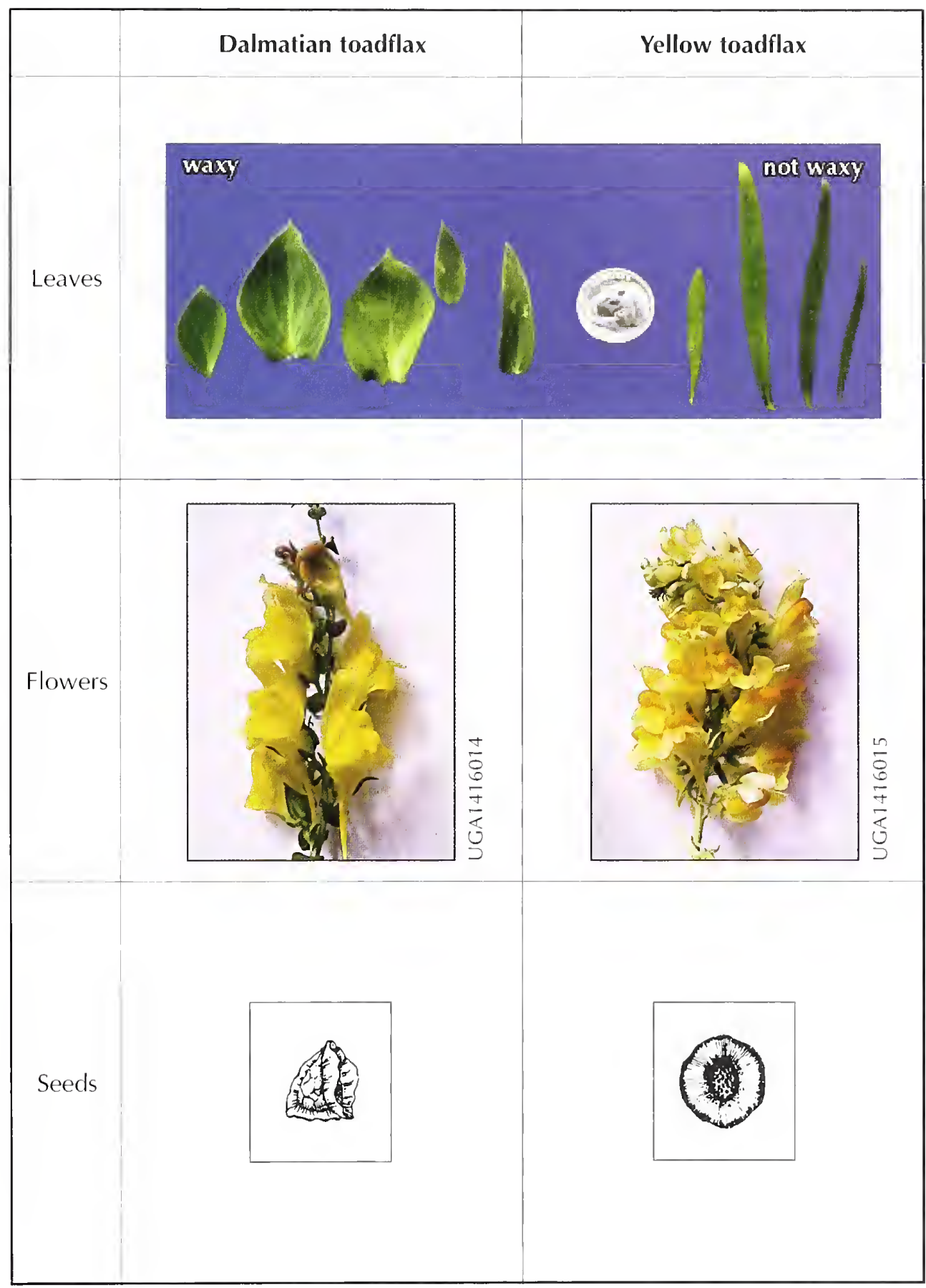




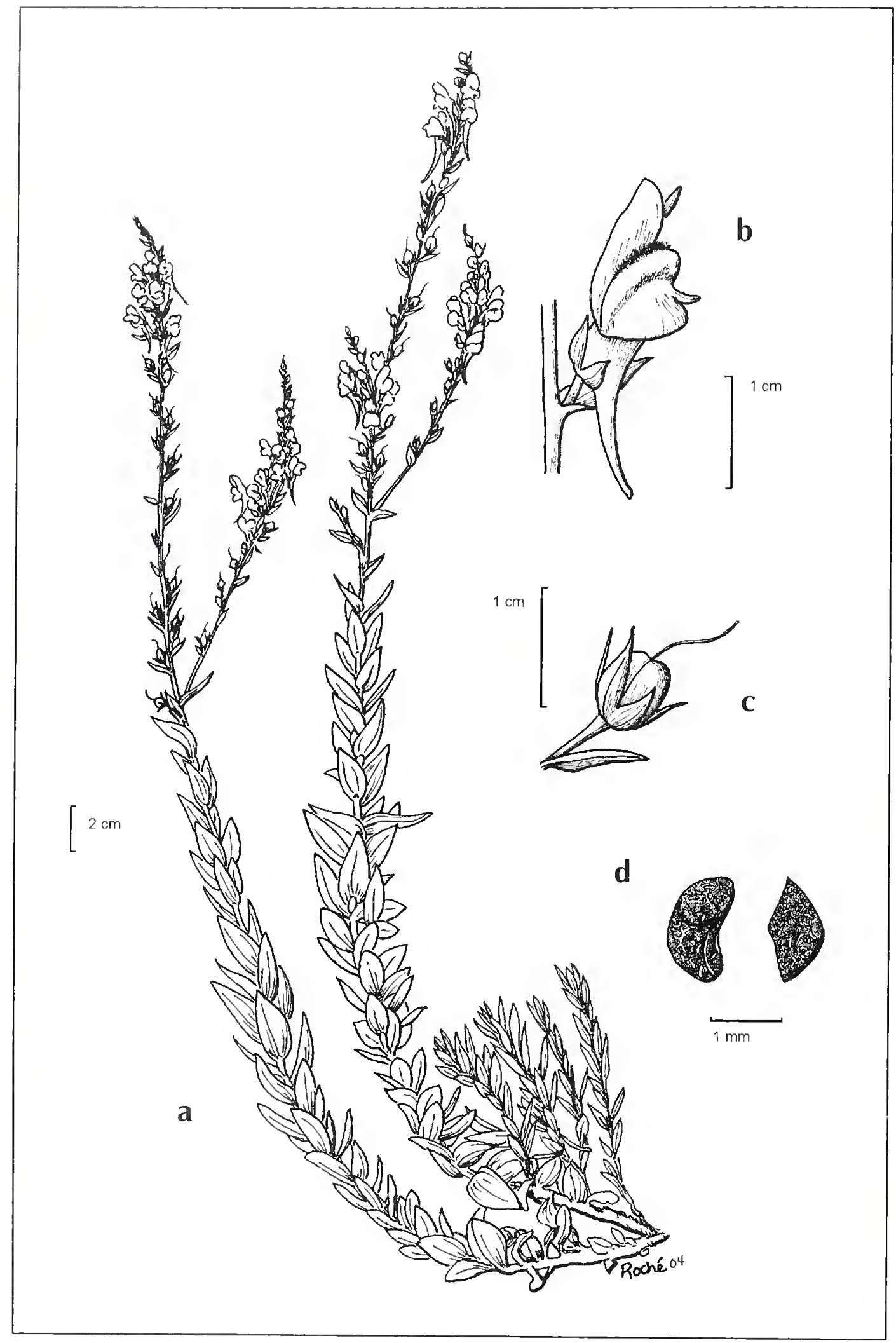

Figure 15. Dalmatian toadflax a) plant, b) flower, c) capsule, and d) seeds. 


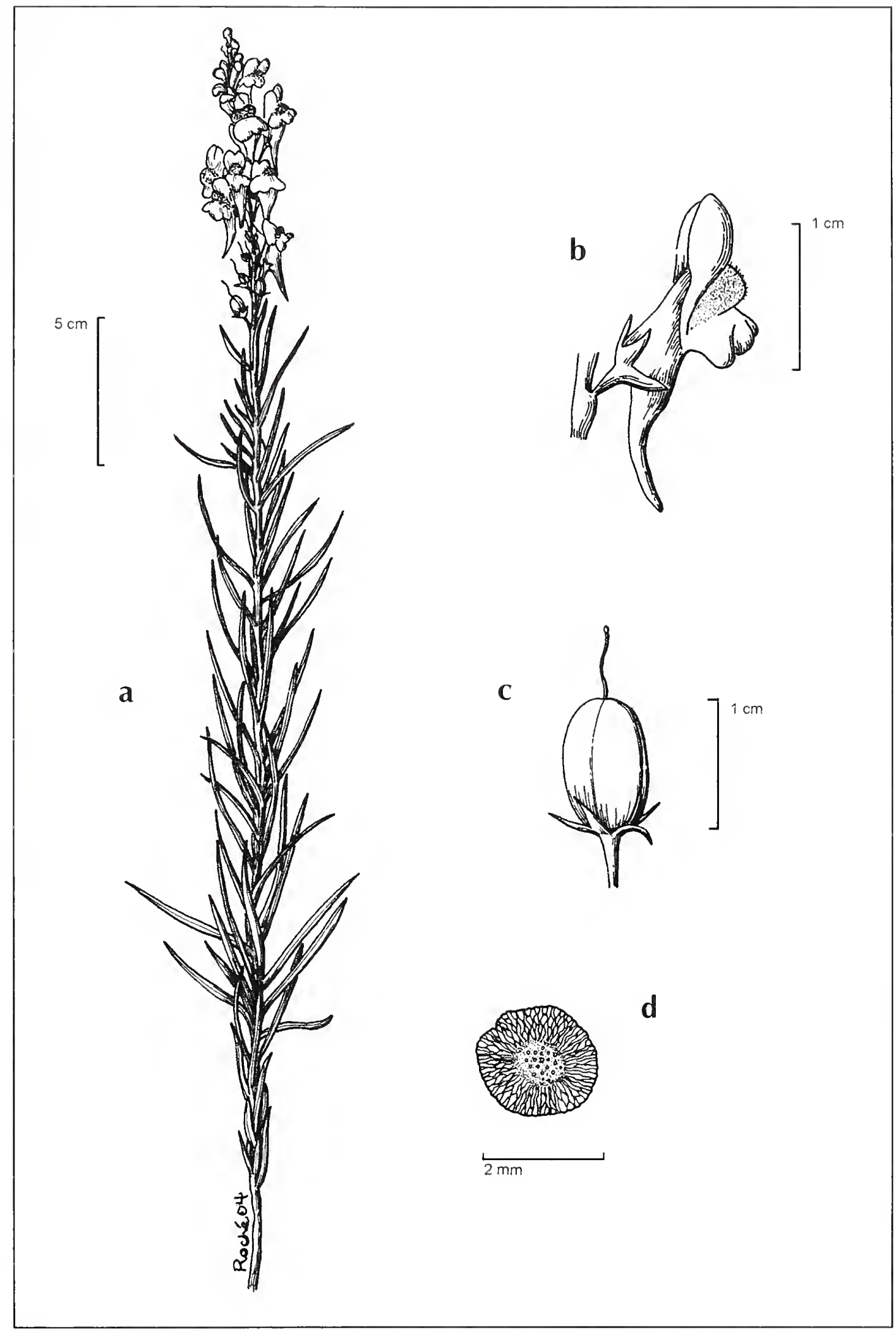

Figure 16. Yellow toadflax a) plant, b) flower, c) capsule, and d) seed. 


\section{CHAPTER 2}

\section{Biology of Toadflax Biocontrol Agents}

\section{Basic Insect Biology}

Insects are a very large, diverse class of animals. Knowing basic insect anatomy and biology can help land managers recognize and identify biocontrol insects in the field. Adult insects have several unique characteristics: 1) an exoskeleton (external skeleton), 2) a segmented body comprised of three distinct regions: head, thorax, and abdomen, and 3) three pairs of legs (Fig. 17). Biological control agents for toadflax have a life cycle with four distinct stages - egg, larva, pupa, and adult (Fig. 18). This form of development is called complete metamorphosis.

Immature insects also have an external skeleton that they must shed in order to grow. The process of shedding the exoskeleton is called molting. The stage of the insect between successive molts is called an instar. As larvae, insects generally complete three to five molts. The mature larva then molts into a pupa, the nonfeeding stage when the insect changes from a larva to an adult.

Insect Body Parts:
a - head
b - antenna
c - thorax
d - abdomen
e - wing

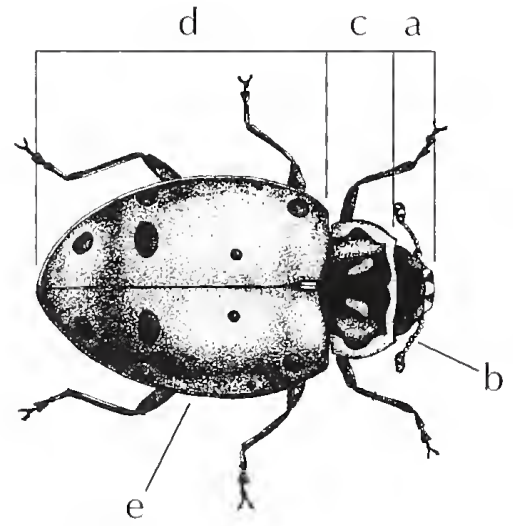

(membranous wings under hard elytra)

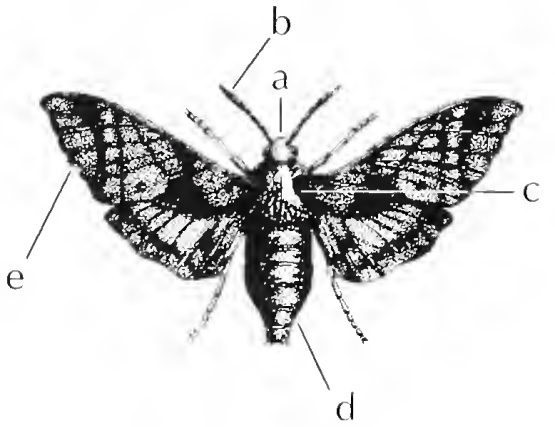

d

Figure 17. Diagram of insect anatomy. 


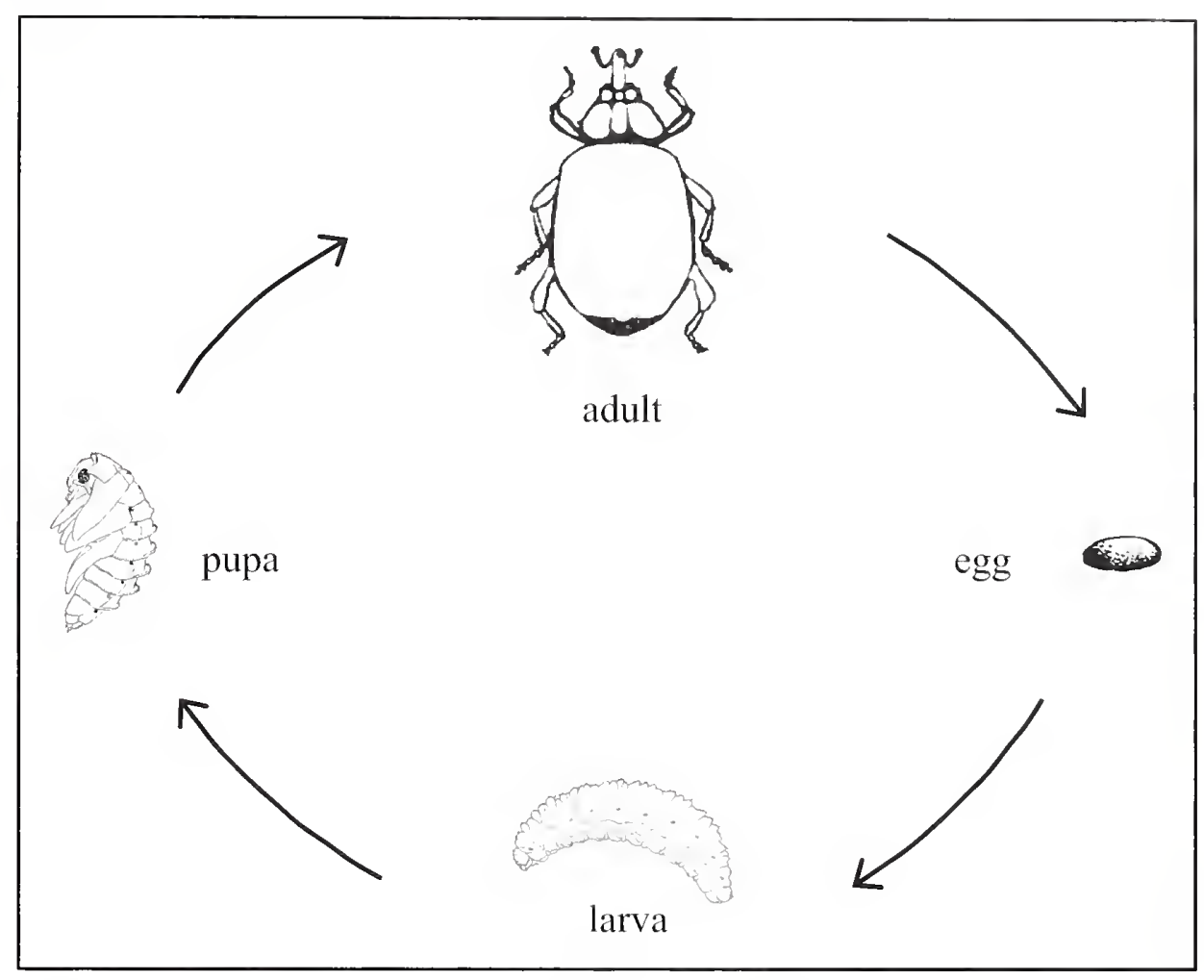

Figure 18. Insect life stages characteristic of complete metamorphosis.

\section{Toadflax Biocontrol Insects}

Eight species of exotic insects have been intentionally or accidentally introduced for biocontrol of toadflax in North America. They belong to two groups: beetles (Order: Coleoptera) and moths (Order: Lepidoptera). Adult beetles are hard-bodied insects with tough exoskeletons. Adult beetles have two pairs of wings; the front pair is thickened to form a hard covering, called the elytra, which meet in a straight line down the middle of the back and cover the larger, membranous hind wings that are used for flight.

\section{Beetles}

Species from two different families of beetles are used for toadflax biocontrol: snout beetles, or weevils (Curculionidae) and flower beetles (Kateridae). Weevils are plantfeeding beetles with chewing mouth parts at the tip of a long snout. They use their snouts to chew inside plant tissues to feed or to notch out holes in which they lay their eggs. Some adult weevils cause significant foliar feeding damage. Weevil larvae, which feed internally in the flowers, stems, or roots of plants, often cause more damage to plants than adult weevils. 
Adult flower beetles are small, dark, oval insects that eat leaves, young stems, and occasionally floral tissues and pollen. Flower beetle larvae live inside the flower and consume floral tissue, pollen, and developing seeds. Both larval and adult flower beetles can cause significant feeding damage to their host plant.

\section{Moths}

Adult moths are soft-bodied insects, with two pairs of membranous wings covered with powder-like scales and coiled mouthparts that are adapted to siphoning sap and nectar from plant flowers. They can be bright- or dull-colored. The adults feed very little, if at all, and do not damage their host plant. Moth larvae, known as caterpillars, are active feeders, developing internally or externally on the host plant. The moths used in toadflax biocontrol belong to two families: the Noctuidae and the Cosmopterigidae.

Toadflax biocontrol agents are listed in Table 2. They include a flower-feeding beetle, a defoliating moth, two root-boring moths, a stem-mining weevil, two seed-feeding weevils, and a root-galling weevil. Thus, roots, stems, flowers, and foliage are all attacked by the toadflax biocontrol agents. Biocontrol agents attack either Dalmatian or yellow toadflax, or both. Table 3 describes the toadflax species and plant parts attacked by each biocontrol agent. Each insect species is described in detail in the following sections. 
Table 2. Toadflax biological control agents.

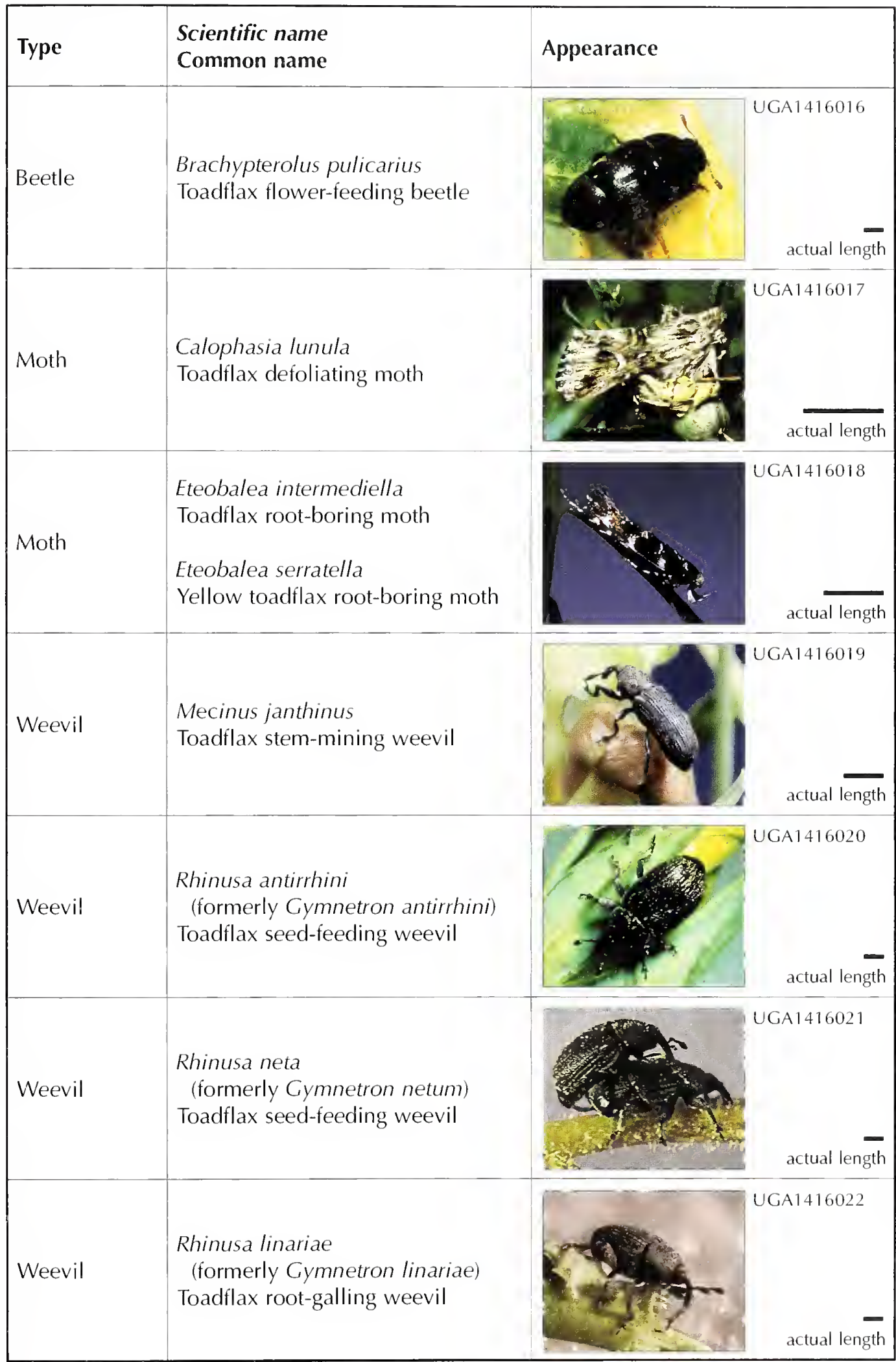


Table 3. Toadflax biocontrol agents established in North America and the species of toadflax they attack primary host, $\bigcirc=$ secondary host)

\begin{tabular}{|c|c|c|c|}
\hline \multicolumn{2}{|r|}{ Biocontrol Agents } & \multicolumn{2}{|c|}{ Toadflax Species Attacked } \\
\hline Plant Part & Species & Dalmatian & Yellow \\
\hline Flowers & $\begin{array}{l}\text { Brachypterolus pulicarius } \\
\text { Dalmatian toadflax biotype } \\
\text { Yellow toadflax biotype }\end{array}$ & $\stackrel{\bullet}{\circ}$ & $\stackrel{0}{0}$ \\
\hline Leaves & Calophasia lunula & - & ○ \\
\hline Roots & Eteobalea intermediella & ○ & - \\
\hline Roots & Eteobalea serratella & 0 & - \\
\hline Stems & Mecinus janthinus & - & 0 \\
\hline Seed capsules & $\begin{array}{l}\text { Rhinusa antirrhini* } \\
\text { Dalmatian toadflax biotype } \\
\text { Yellow toadflax biotype }\end{array}$ & $\stackrel{\bullet}{0}$ & $\begin{array}{l}0 \\
0\end{array}$ \\
\hline Seed capsules & $\begin{array}{l}\text { Rhinusa neta* } \\
\text { Dalmatian toadflax biotype } \\
\text { Yellow toadflax biotype }\end{array}$ & $\bigcirc$ & $\begin{array}{l}0 \\
0\end{array}$ \\
\hline Roots & Rhinusa linariae* & - & - \\
\hline
\end{tabular}

*formerly Gymnetron 


\section{Brachypterolus pulicarius $\mathrm{L}$.}

Common name: Toadflax flower-feeding beetle

Order: Coleoptera

Family: Kateridae (formerly Nitidulidae - see Note on page 27)

Brachypterolus pulicarius adults are dark brown to black, somewhat oval-shaped, 0.12 in $(3 \mathrm{~mm})$ long beetles (Fig. 19). This minute beetle was accidentally introduced from Europe into eastern North America during the early 1900s, probably with yellow toadflax plants that were imported for medicinal and/or ornamental purposes. The toadflax flower-feeding beetle is now found across the United States and Canada. The most common biotype of the beetle prefers to feed on the flowers of yellow toadflax. Another biotype, found in Canada and released in the northwestern United States, attacks Dalmatian toadflax.

The adult flower-feeding beetles emerge from the soil in late spring, where they have overwintered either as pupae, or as adults (in warmer climates), and live for about eight weeks after emergence. Upon emerging, adults feed briefly on young, succulent shoot tips and axillary buds in the toadflax leaf axils before mating. Adult beetles also can feed on the pollen of early spring-blooming plants such as dandelion, clovers, wild mustards, strawberry, apple, and dogwood. After mating, females begin laying eggs in early June into unopened toadflax buds, just beneath the folded petals. The eggs at first appear milky white, becoming yellow

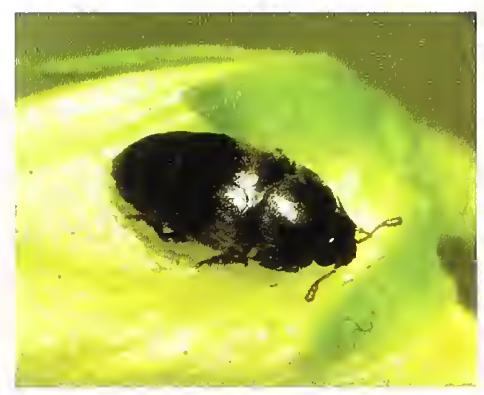

Figure 19. Brachypterolus pulicarius adult. UGA1416023 just before hatching. Usually only one egg is laid per bud, but up to three eggs can be

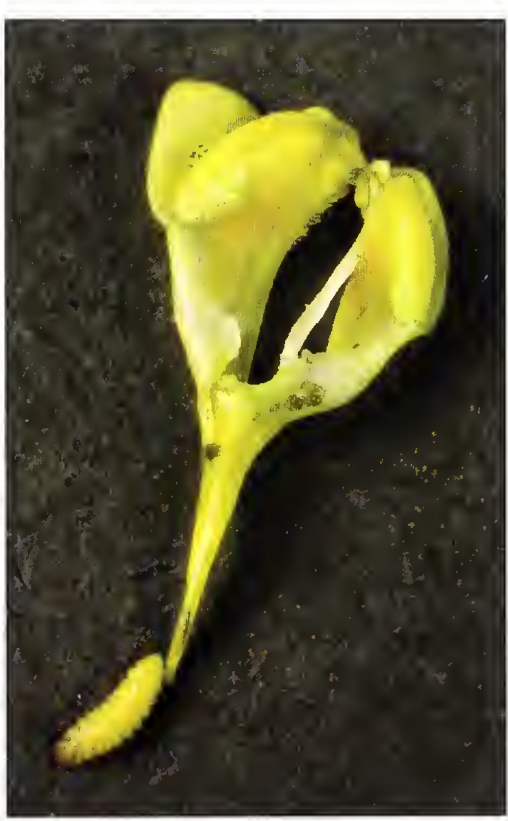
found in a single bud.

When the eggs hatch in three to seven days, the small, yellow larvae move directly into the developing ovary of the flower. Initially the larva's head capsule is dark brown to black and wider than the abdomen, but by the third instar, it lightens to a golden brown and becomes more slender than the body (Fig. 20). Larvae feed on the pollen, anthers, and ovaries in buds and flowers. Older larvae consume immature seeds. Larvae reach a length of 0.3 in $(7.5 \mathrm{~mm})$ within two to five weeks after completing three instars. Mature larvae leave the flowers and move into the soil to pupate for the duration of the winter. This beetle has one generation per year (Fig. 21).

Figure 20. Brachypterolus pulicarius larva at the base of a toadflax flower. UGA1416001 


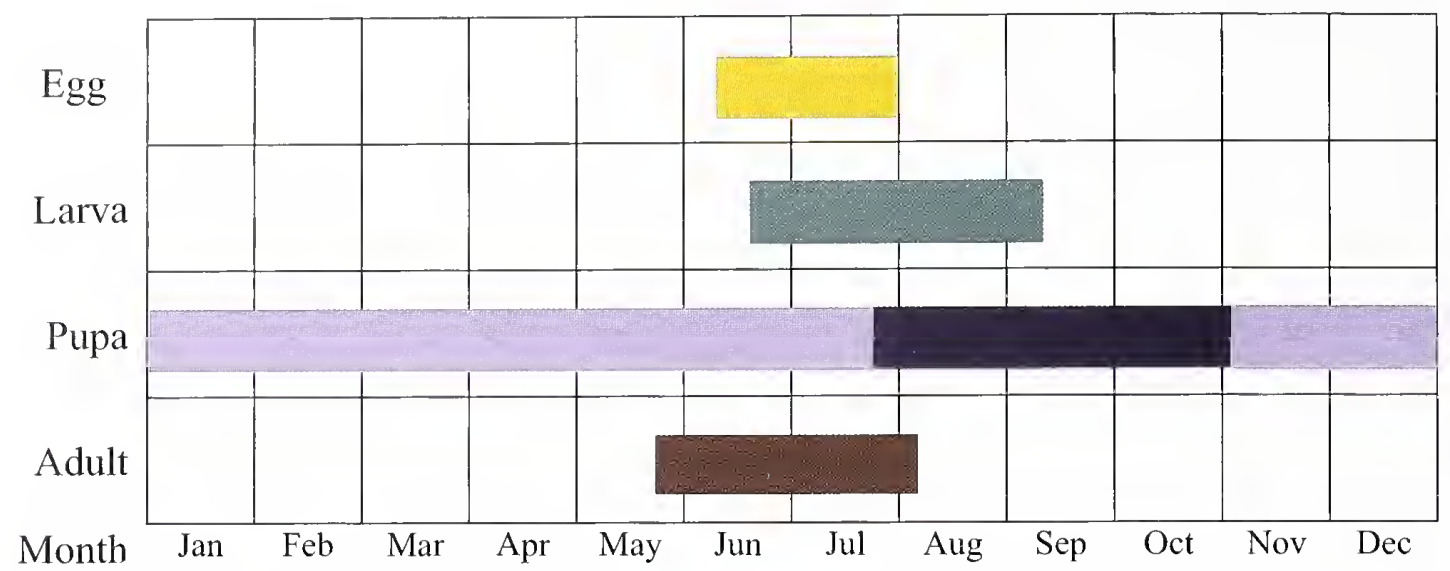

Figure 21. Schematic life cycle of Brachypterolus pulicarius. Colored bars indicate the approximate length of activity for each of the life stages. The light blue bar represents the overwintering pupa.

\section{Host Specificity}

Field observations have shown that the flower-feeding beetle has a narrow bost range. Larvae appear to complete their life cycle only on Dalmatian and yellow toadflax. Adult beetles may consume the pollen of many plant species, but pollen feeding causes little or no impact, and the beetle does not oviposit into the flowers of these nontarget plant species.

\section{Impact}

At high densities adult feeding on toadflax shoots causes increased branching (both primary and secondary) and reduced plant height in Dalmatian toadflax (Fig. 22). At yellow toadflax sites heavily infested with flower-feeding beetles, adult feeding on shoot tips can delay the onset of flowering by almost a month and reduces the number of healthy, intact blossoms in the first flowering flush by 97 percent. Later season flowering of toadflax is also suppressed, with fewer seeds produced.

The larvae generally cause more damage to toadflax than the adults. Larval feeding inside yellow toadflax flowers, for instance, severely impairs seed production, often reducing seed output by 75 percent or more. Seeds that survive to maturity are smaller, lighter weight, and less viable than normal seeds. When larvae have consumed all the floral tissues and developing seeds in a flower, they move to other flowers on the plant in search of additional food. In laboratory tests, individual larvae consumed the contents of as many as six flowers.

The greatest impact on seed production is achieved when the flower-feeding beetle occurs with the seed-feeding weevil. Together, the two biocontrol agents can nearly eliminate seed production at some sites. 


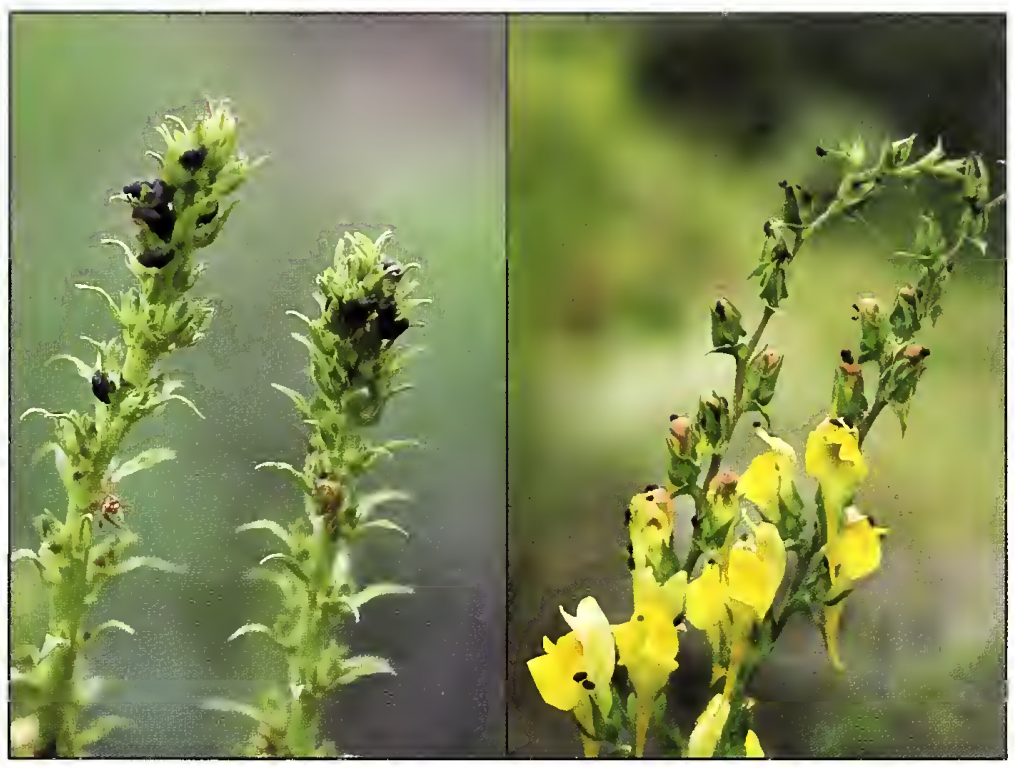

Figure 22. Brachypterolus pulicarius adults on a) yellow and b) Dalmatian toadflax. UGA1416025, UGA1416026

\section{Comments}

Adult flower-feeding beetles are good fliers and disperse readily to find new toadflax infestations. The yellow toadflax biotype of the flower-feeding beetle is well-established in Colorado, Idaho, Oregon, Montana, South Dakota, Utah, Washington, and Wyoming, throughout the northeastern United States, and in western Canada (e.g., Alberta, British Columbia, and Saskatchewan). The Dalmatian toadflax biotype of the beetle is established in Alberta, British Columbia, Idaho, Montana, and Washington.

One imported specialist wasp has been found to parasitize the larval stages of the flower-feeding beetle in the western United States. Generalist predators such as spiders have been seen preying on adult beetles. Predation of larvae has not been reported. Cannibalism can occur when multiple larvae feed within the same flower. In addition, larvae of the flower-feeding beetle will eat the eggs and young larvae of the seed-feeding weevil.

The flower-feeding beetle is similar in general appearance to the toadflax seed-feeding weevils, Rhinusa antirrhini and $R$. neta. However, the flower-feeding beetle is not a weevil and thus does not have a long, conspicuous weevil snout.

Note: The genus Brachypterolus formerly belonged to the beetle family Nitidulidae. However, recent taxonomic changes now place Brachypterolus in the family Kateridae, also known as the Cateretidae or the Kateretidae. 


\section{Calophasia lunula (Hufnagel)}

Common name: Toadflax defoliating moth

Order: Lepidoptera

Family: Noctuidae

Calophasia lunula (Fig. 23) is a defoliating moth introduced from Europe for biocontrol of yellow and Dalmatian toadflax. Released in the early 1960s, this was the first biological control agent intentionally introduced to control toadflax. Multiple introductions of C. lunula and frequent redistributions since the 1960s have resulted in the widespread occurrence of this moth in the United States and southern regions across Canada.

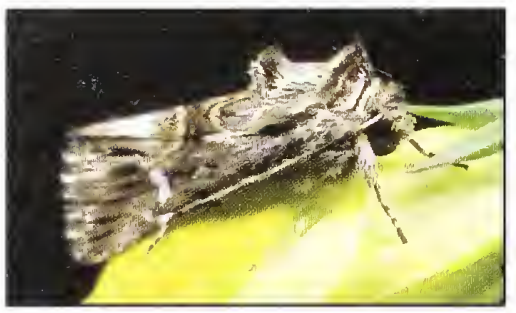

Figure 23. Calophasia lunula adult. UGA1416027

Adult moths are mottled grey-brown in color, with light and dark markings on the wings, 0.4 to 0.6 in (10 to $15 \mathrm{~mm}$ ) long, and have a wingspan of 1 to 1.2 in $(25.4$ to $30.5 \mathrm{~mm})$. Adults emerge in May from cocoons where they have overwintered and live for only 10 to 14 days. After a brief period feeding on flower nectar of toadflax and other plants, the nightactive adults spend the remainder of their short lifespan mating and laying eggs. Females lay ribbed, cream-colored eggs singly on the foliage and flowers. A female can lay between 30 and 80 eggs during her brief lifetime.

Larvae hatch from the eggs in about 10 days. The first instars are pale gray in appearance, but develop into large, brightly colored caterpillars 1.5 to 1.8 in ( 3.8 to $4.6 \mathrm{~cm}$ ) in length, with black and yellow parallel stripes dotted with white spots (Fig. 24). Larvae preferentially feed on young, tender leaves, but also will eat lower stem leaves as plants become increasingly defoliated.

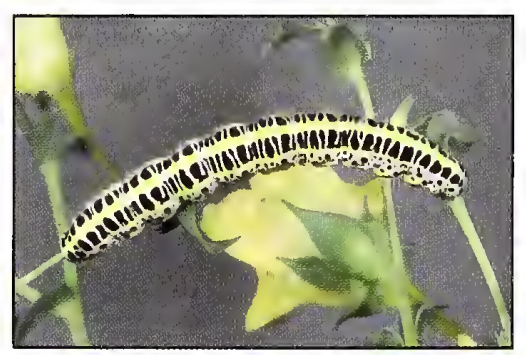

Figure 24. Calophasia lunula caterpillar. GA1416028

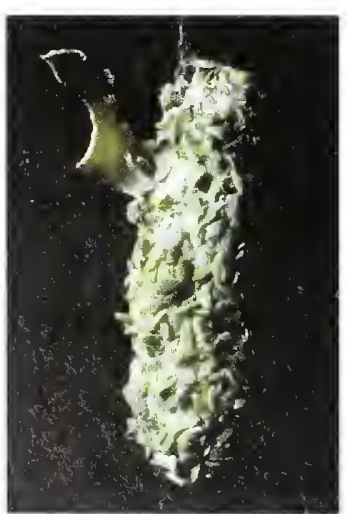

After the fifth instar, mature caterpillars move to the base of the plant and construct silk-lined cocoons from chewed leaves, soil particles, and litter (Fig. 25). Each larva becomes a reddish-brown pupa inside the cocoon. Pupation lasts one week and new generation adults emerge soon after to begin a new generation. Depending on weather conditions and the length of the growing season, one to three generations per year are completed by this moth (Fig. 26). The moth overwinters as a pupa inside the cocoon, which is attached to the stem base or lies in the soil or plant litter near the base of a plant.

Figure 25. Calophasia lunula cocoon. A1416001 


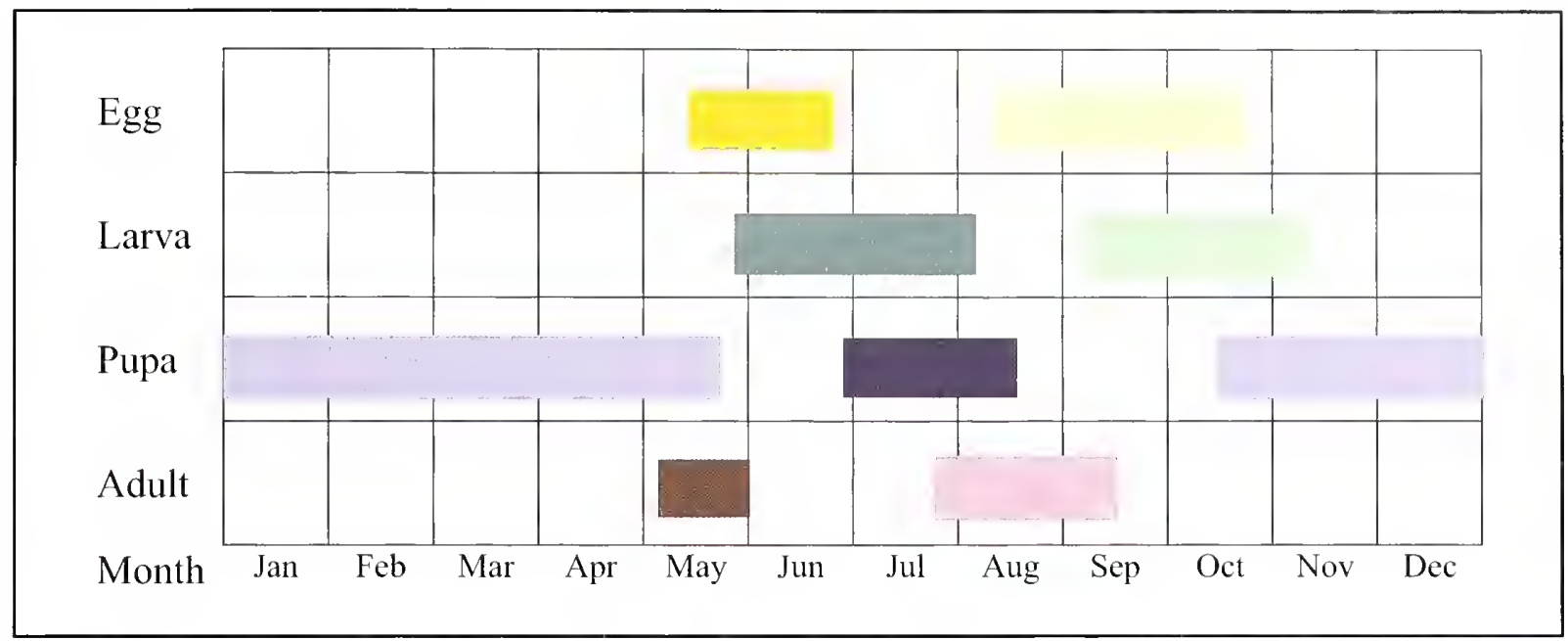

Figure 26. Schematic life cycle of Calophasia lunula. Colored bars indicate the approximate length of activity for each of the life stages. Light colored bars indicate the possible second generation for this moth. The light blue bar represents the overwintering pupa.

\section{Host Specificity}

Field observations of this agent in North America have shown that the defoliating moth has a relatively broad host range. Caterpillars are known to feed and develop on plants from the genus Antirrbinum, including common non-native, ornamental snapdragons and one native species, Sairocarpus virga (formerly Antirrbinum virga). Because C. Iunula poses a risk to nontarget plant species in genera other than Linaria, some land managers have ceased collecting and redistributing the defoliating moth.

\section{Impact}

Caterpillars of the toadflax moth can severely defoliate both Dalmatian and yellow toadflax, especially at favorable sites where their density is high (Fig. 27). Severe defoliation of seedlings and one-year old plants can be fatal; older, larger plants can usually withstand defoliation, although defoliated plants are less vigorous and may produce fewer flowers. Defoliation of an entire patch of toadflax by this moth has not been documented.

Figure 27. Defoliation of Dalmatian toadflax by Calophasia lunula (three visible larvae). UGA1416030

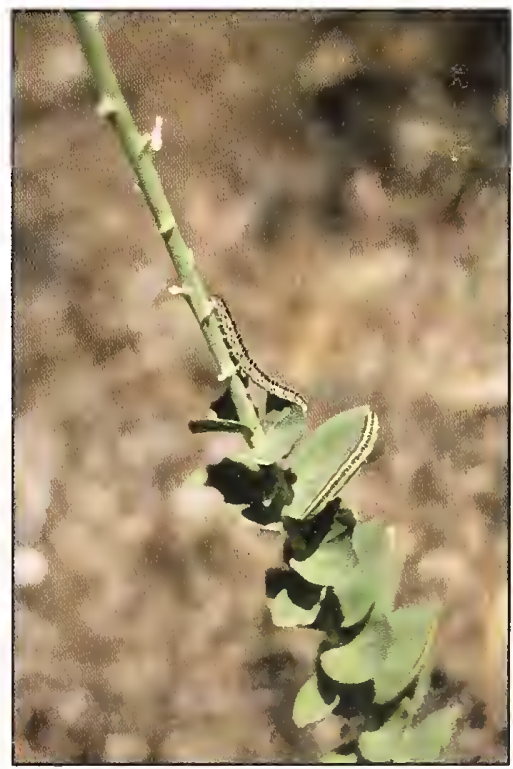


The greatest impact of the toadflax defoliating moth is on seedlings and small plants which may be killed by defoliation and where the moth occurs with other biocontrol agents. For example, plants attacked by the stem-mining weevil that are also defoliated by the toadflax moth might be more severely affected than plants attacked by either biocontrol agent alone.

\section{Comments}

The toadflax defoliating moth prefers warm, dry sites with coarse-textured soils. Most caterpillars are found in relatively sparse toadflax infestations. The defoliating moth requires a sufficiently long growing season to develop (at least 545 degree-days over $56^{\circ} \mathrm{F}\left(13.5^{\circ} \mathrm{C}\right)$ ). This requirement limits its range in northern latitudes (e.g., in Canada) and at higher elevations in southern latitudes.

Parasitism and pathogens of the caterpillars and pupae of the toadflax moth have been reported. However, predation of the caterpillars has not been reported. 


\section{Eteobalea intermediella Riedl.}

Common name: Toadflax root-boring moth

\section{Eteobalea serratella Treitschke}

Common Name: Yellow toadflax root-boring moth

Order: Lepidoptera

Family: Cosmopterigidae

Two toadflax root-boring moths, Eteobalea intermediella and E. serratella, have been introduced from southern Europe for control of toadflax. E. intermediella was approved for release in Canada in 1991 and E. serratella in 1992. Both species were approved for release in the United States in 1995. E. intermediella (Fig. 28) attacks both Dalmatian and yellow toadflax equally, whereas $E$. serratella prefers yellow toadflax. E. intermediella adults and larvae are very similar in appearance to those of E. serratella; the two species can only be distinguished by examining the surface texture of the eggs under a microscope (Fig. 29). Although both of these species were released at several locations in the United States and Canada, populations of the moths have not been recovered, so their establishment in North America cannot be confirmed.

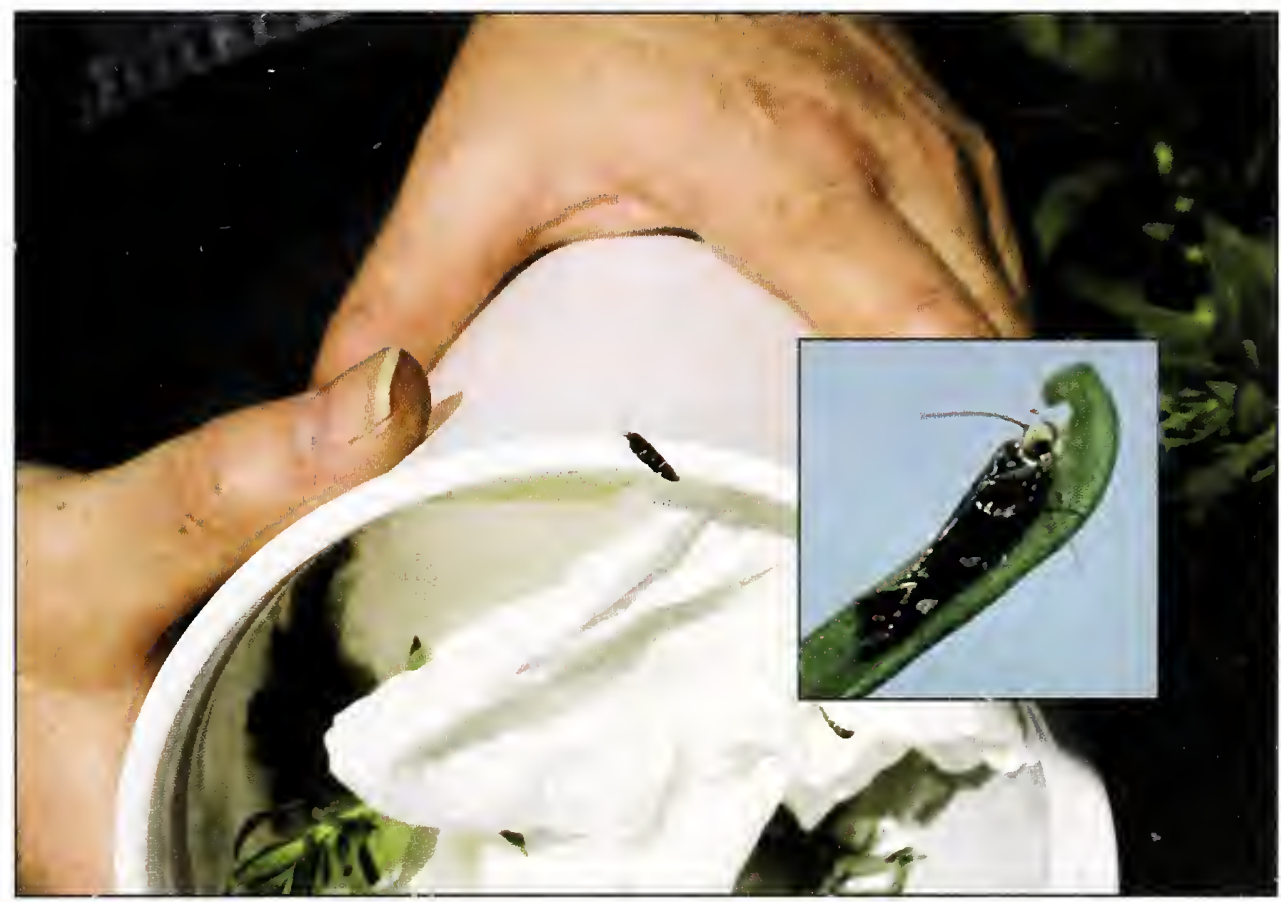

Figure 28. Eteobalea intermediella adults. UGA1416031 (inset) 


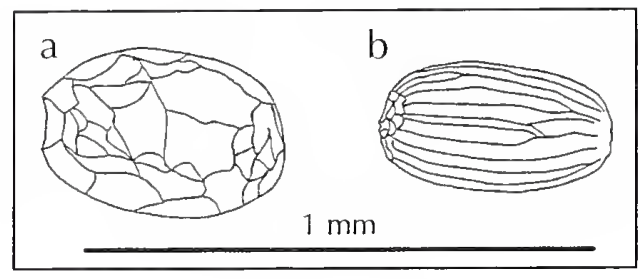

Figure 29. Egg surface texture of a) Eteobalea intermediella and b) E. serratella.

Adult moths are slender, about 0.3 to 0.4 in $(7.5$ to $10 \mathrm{~mm})$ long, and have white and gold spots over a dull, dark brown to black body, with a wingspan of 0.6 to 0.7 in (15 to $18 \mathrm{~mm}$ ). The dull color and small size of these moths make them difficult to detect in the field. Adults are active during twilight periods (just after dusk and just before dawn).

Adults appear in late spring from cocoons and live for only a few weeks. They do not feed, spending their entire, brief lifetime mating and laying eggs. E. intermediella lays eggs in loose strings of three to eight eggs in the lower leaf axils or on the base of yellow toadflax and nonflowering Dalmatian toadflax stems. E. serratella lays eggs in loose strings of three to eight eggs at the base of yellow toadflax stems, or on the soil surface. Each female of both species can lay up to 180 eggs during her brief lifetime. Larvae hatch in seven to 10 days and bore into the stem or root, moving to the root crown where they feed on internal plant tissue inside tunnels they carve out and line with silk. The caterpillars are cream-colored, with a brown head capsule (Fig. 30), and mature through five instars to a length of $0.5 \mathrm{in}(12.5 \mathrm{~mm})$. Mature larvae tunnel back to the root crown or up into the base of a stem to construct a cocoon in which to pupate.

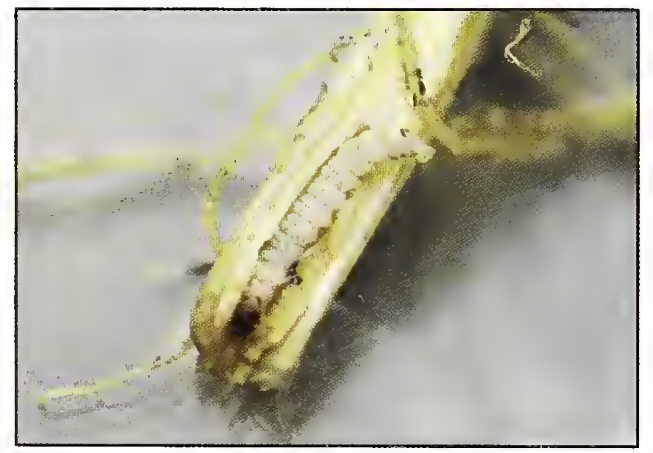

Figure 30. Eteobalea intermediella larva in toadflax root. UGA1416032 
Eteobalea serratella has only one generation per year, overwintering as larvae in the roots and pupating the following spring (Fig. 31a). In contrast, E. intermediella has two generations per year (Fig. 31b) (a third generation is possible in warm climates with a longer growing season). After a brief 10 -day pupation period, new $E$. intermediella adults emerge in July as the second generation. They quickly mate and lay eggs, and larvae of the second generation feed inside the roots through the autumn and winter. Both species pupate in silken cocoons the following spring and adults emerge through a small hole in the base of the stem 10 to 14 days later.

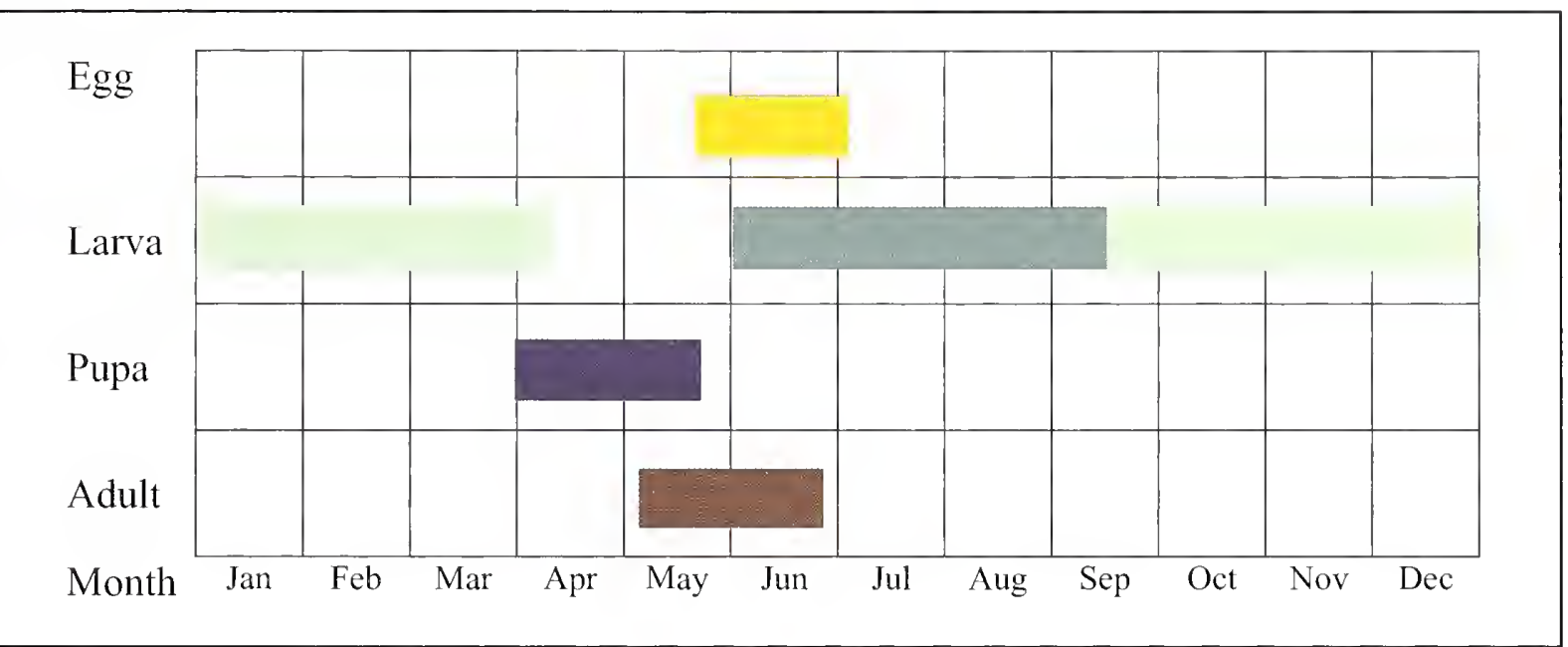

Figure 31a. Schematic life cycle of Eteobalea serratella. Colored bars indicate the approximate length of activity for each of the life stages. The light green bars represent the overwintering larva.

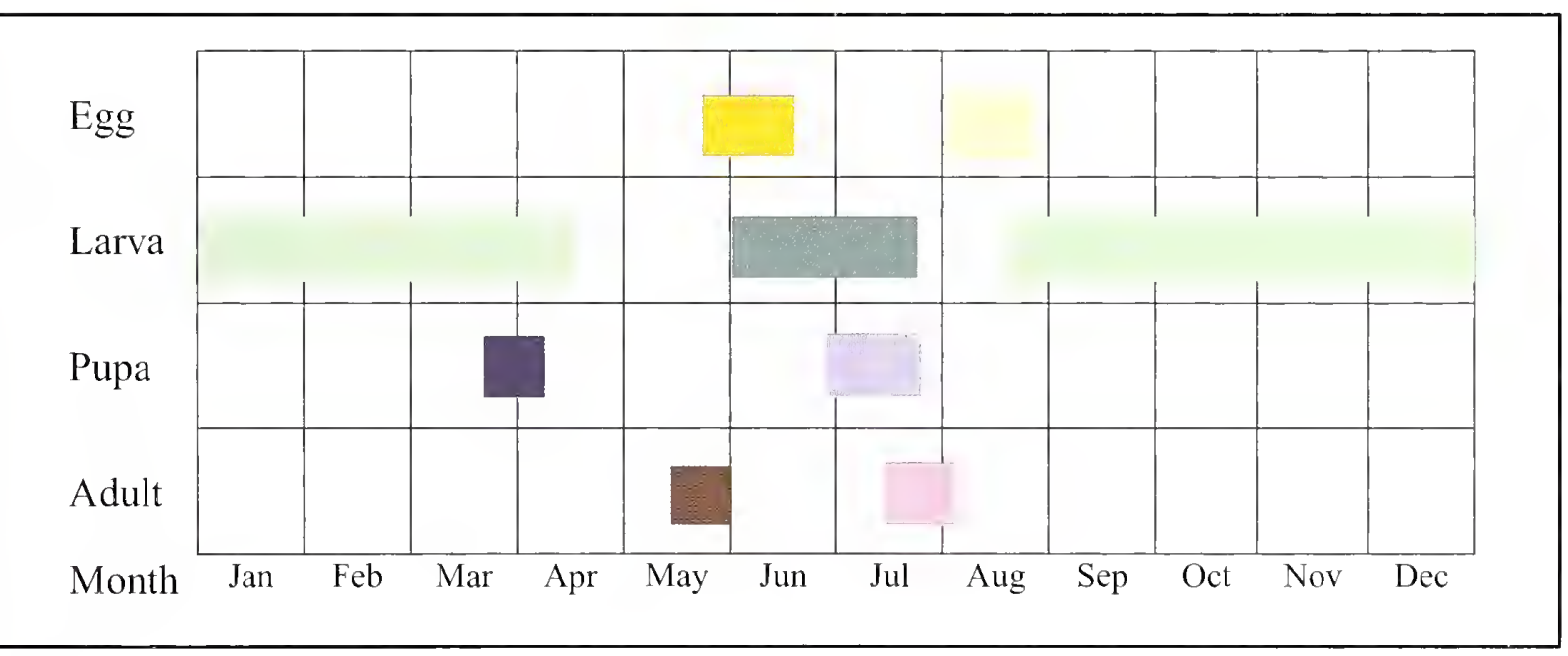

Figure 31b. Schematic life cycle of Eteobalea intermediella. Colored bars indicate the approximate length of activity for each of the life stages. Light-colored bars indicate the second generation. The light green bars represent the overwintering larva. 


\section{Host Specificity}

Experiments conducted in Europe have shown that the root-boring moths have a narrow host range. In addition to Dalmatian and yellow toadflax, the moths are able to feed and complete development on plants in the genera Antirrbinum and Kickxia.

\section{Impact}

The impact of both root-boring moths on toadflax is identical. In studies conducted in Europe, three to seven larvae can be found within a single root of a toadflax plant, depending on the size of the roots. Root tunneling and boring by moth larvae does not usually kill toadflax plants directly. However, attacked plants are generally less vigorous, have fewer flowers, and produce fewer seeds than unattacked plants.

\section{Comments}

Attempts to establish these moths have not yet proven successful. However, a small propagation colony of E. serratella is established in test plots in central British Columbia. Ongoing studies will hopefully determine the specific site and environmental conditions required by these moths. 


\section{Mecinus janthinus Germar}

Common Name: Toadflax stem-mining weevil

Order: Coleoptera

Family: Curculionidae

Mecinus janthinus adults are elongate, elliptical, metallic-bluish-black weevils, 0.2 in $(5 \mathrm{~mm})$ long, with a pronounced snout (Fig. 32). This species was first released in Canada against Dalmatian and yellow toadflax in 1991, and was subsequently approved for release in the United States in 1995. The sexes are easily differentiated by examining their legs under a dissecting microscope: the male has two distinct spurs (protuberances) on the hind leg, which are in absent in females (Fig. 33).

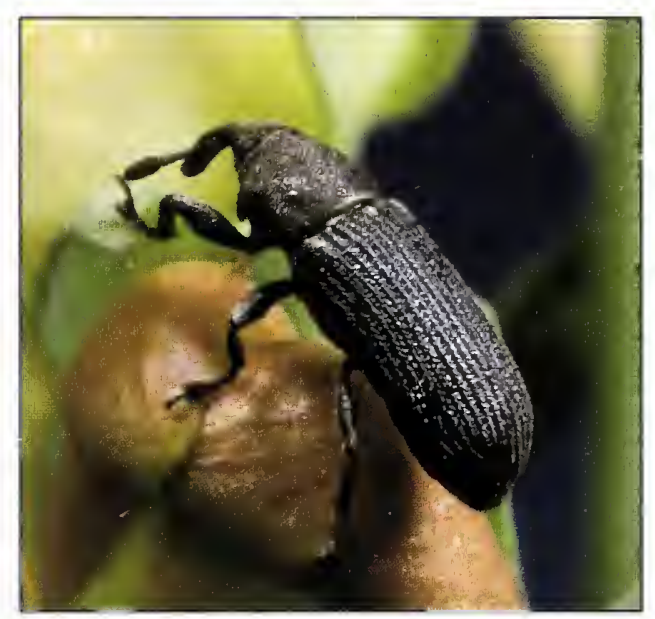

Figure 32. Mecinus janthinus adult. UGA1416019

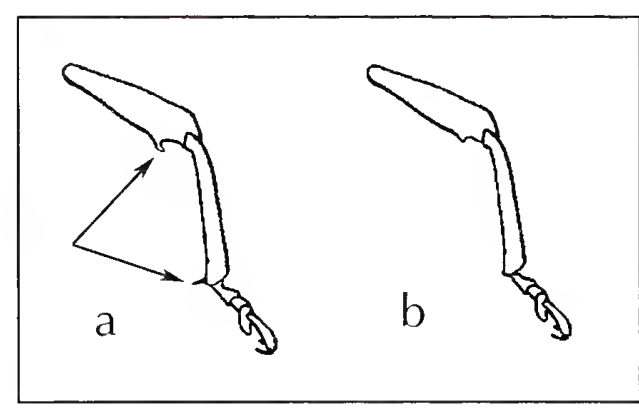

Figure 33. Spurs on the hind leg of Mecinus janthinus adult male (a) that are absent in the female (b). 


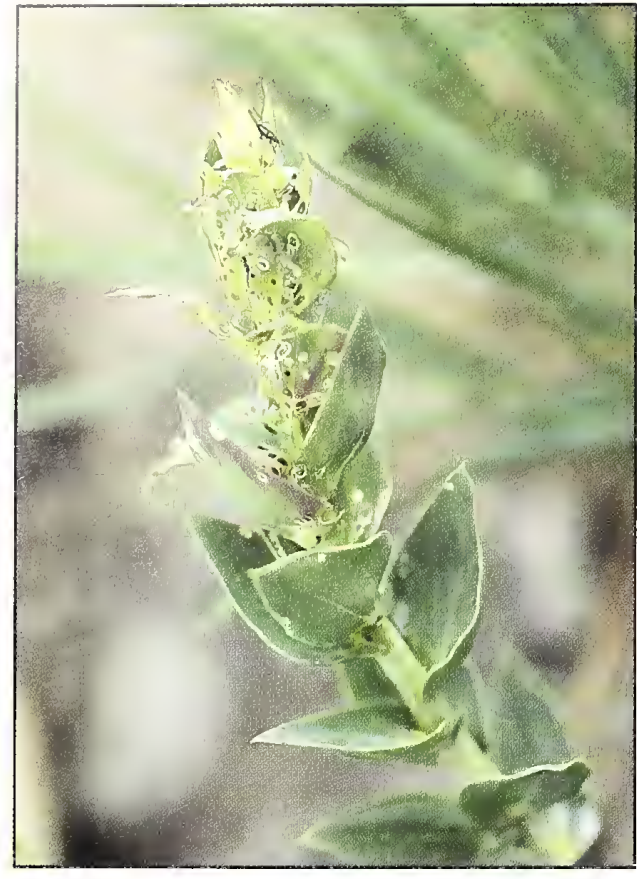

Figure 34. Foliage feeding damage by Mecinus janthinus adults. UGA1416034

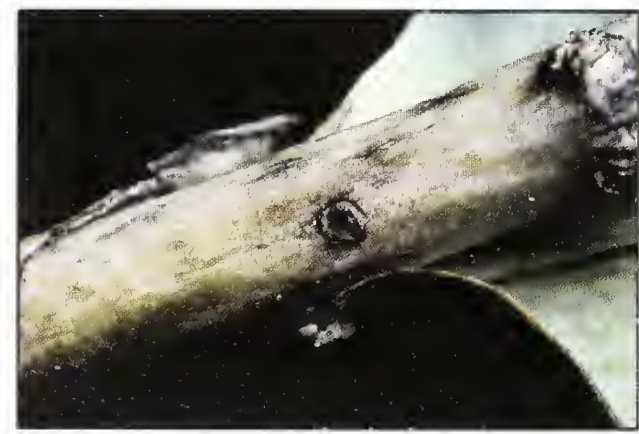

Figure 35. Mecinus janthinus oviposition hole in a Dalmatian toadflax stem. UGA1416001
Depending on weather conditions, overwintered adults may begin emerging from the previous year's stems by early April. They remain active through early July, eating young toadflax shoots. Adults often aggregate in large numbers on the foliage around and beneath the terminal buds where they feed on the succulent foliage and stems, often causing significant damage to the leaves and stem tips (Fig. 34).

After feeding on toadflax shoots, weevils mate and begin oviposition, which lasts from early May through late June. To lay eggs, the female chews a hole into the toadflax shoot and inserts a single, white, oval egg. Each oviposition hole is then covered with a lid of plant tissue to protect the egg from desiccation and predation. The oviposition 'scars' look like discolored bumps or calluses on the stem (Fig. 35). Individual females lay an average of 45 eggs (some lay more than 100 eggs), laying about one egg a day. They prefer to lay eggs into large shoots, but will oviposit in shoots as small as 0.03 in $(0.9 \mathrm{~mm})$ when beetle density is high and competition for larger, more robust stems occurs.

Larvae hatch in six to seven days. The legless, C-shaped larvae are creamy-white, with light brown head capsules, and are about 0.2 in ( $5 \mathrm{~mm}$ ) long (Fig. 36). After hatching, the larvae tunnel within the stem as they feed, moving no further than 1.2 in $(3 \mathrm{~cm})$ from the oviposition site. Larval feeding in thin stems causes them to swell and develop a purplish cast. Development through three larval instars within the shoots takes four to five weeks.

Pupation occurs within an oval chamber formed within the mined toadflax stem by the last larval instar. Pupae (Fig. 37) are 0.1 in $(2.5 \mathrm{~mm})$ long and white initially, turning black as development proceeds.

Adults remain within their pupal cells inside the dead, dried stalks of toadflax to overwinter, chewing their way out of the stem the following spring (Fig. 38).

Only one generation is produced per year (Fig. 39). Stemmining weevils complete their development to adulthood in 50 to 63 days (by late August or early September). 
Figure 36. Mecinus janthinus larva in a Dalmatian toadflax stem. UGA1416036

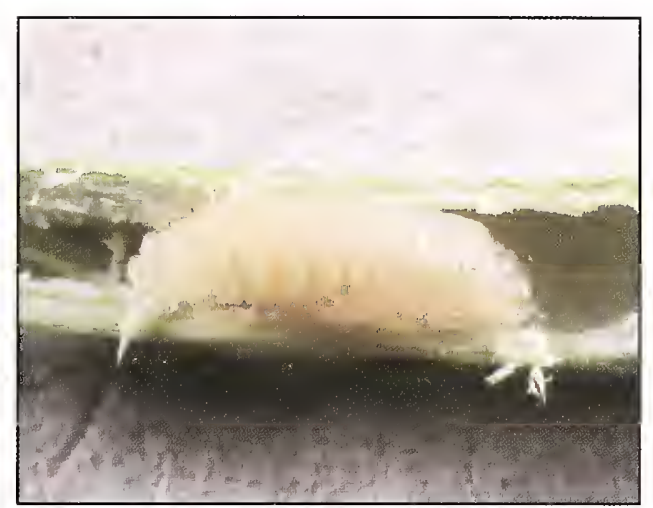

Figure 38. Mecinus janthinus adults emerging from Dalmatian toadflax stems. UGA1416038

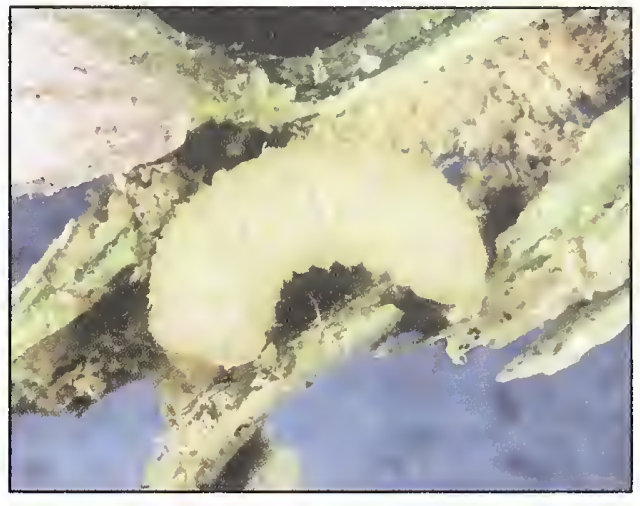

Figure 37. Mecinus janthinus pupa in a Dalmatian toadflax stem. UGA1 416037

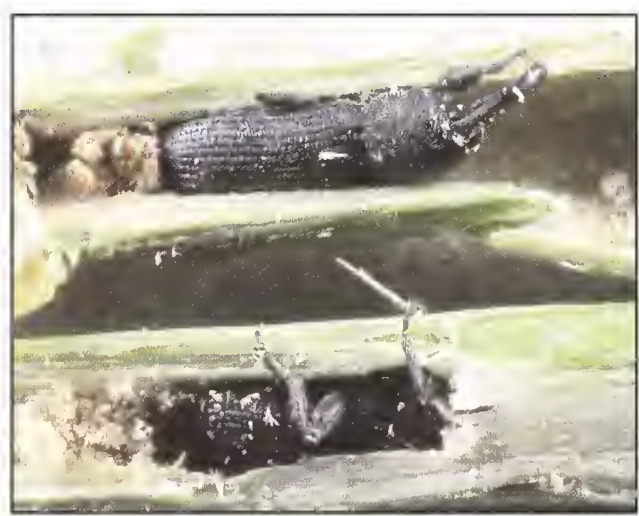

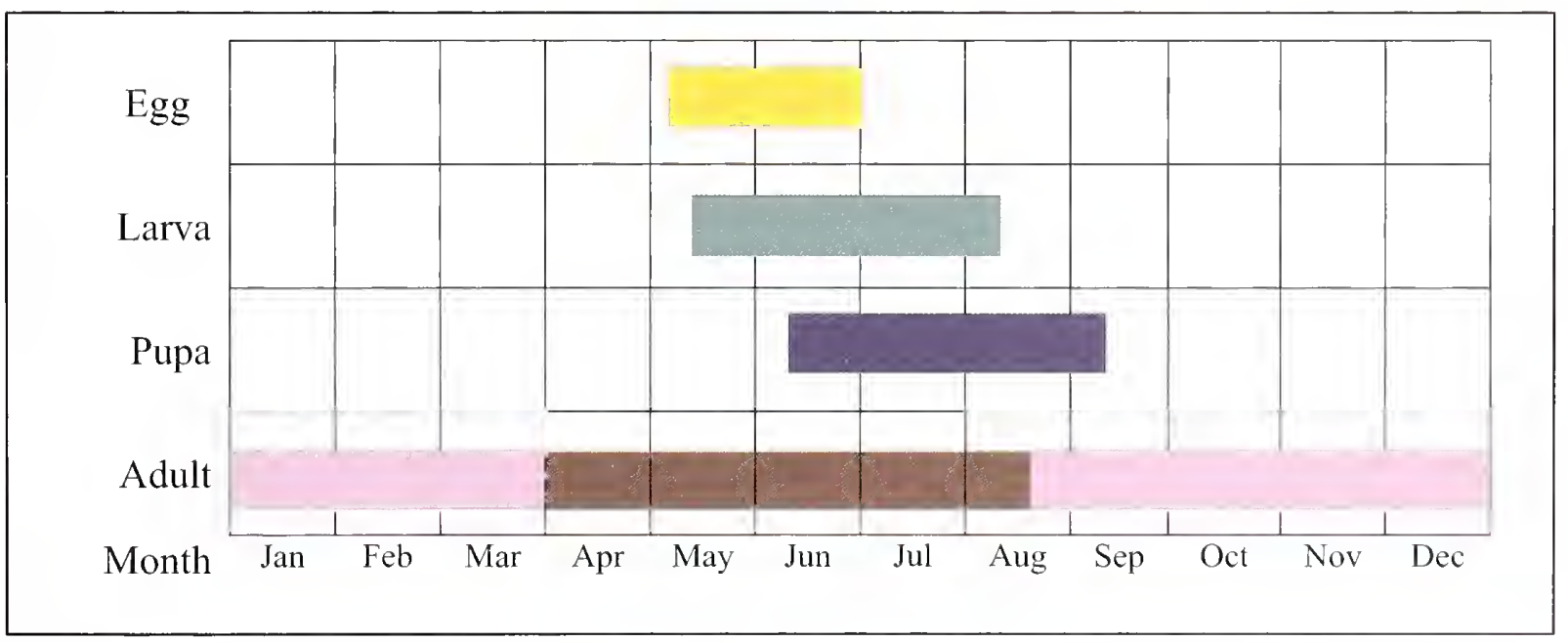

Figure 39. Schematic life cycle of Mecinus janthinus. Colored bars indicate the approximate length of activity for each of the life stages. The light red bar represents the overwintering adult. 


\section{Host Specificity}

Laboratory studies have shown that, in addition to Dalmatian and yellow toadflax, the stem-mining weevil is able to feed and complete development on native hosts, including Maurandella species and Sairopcarpus virga, and on exotic Antirrbinum species commonly used as ornamental plants in North America. However, only Dalmatian and yellow toadflax have been attacked in the field based on surveys to date.

\section{Impact}

Stem-mining weevil adult and larval feeding play a major role in damaging Dalmatian toadflax plants. Adult weevils consume leaves, and chew on stems and the growing tips of toadflax shoots. The damage caused by adults weakens the plant, can suppress flowering and seed production, and severely stunt shoots. At high weevil densities, up to 100 eggs can be laid by a number of different females inside a single, large Dalmatian toadflax shoot. Plant shoots are severely damaged when many insects are in a single stem (Fig. 40).

Larval mining within the toadflax shoot severs the stem's water conducting tissues, causing premature wilting and eventual desiccation of attacked stems (Fig. 41). Nutrient reserves in the roots, important to the year-to-year persistence of individual plants, are also likely depleted.

Studies have shown that repeated, yearly attack by both stem-mining weevil adults and larvae diminishes plant vigor, reduces shoot biomass, and eventually causes reductions in toadflax plant density.

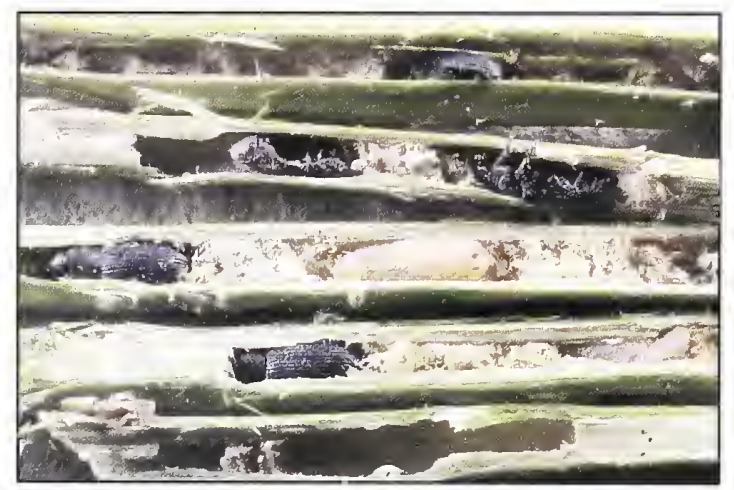

Figure 40. Numerous Mecinus janthinus adults and pupae inside Dalmatian toadflax stems. UGA1416039 


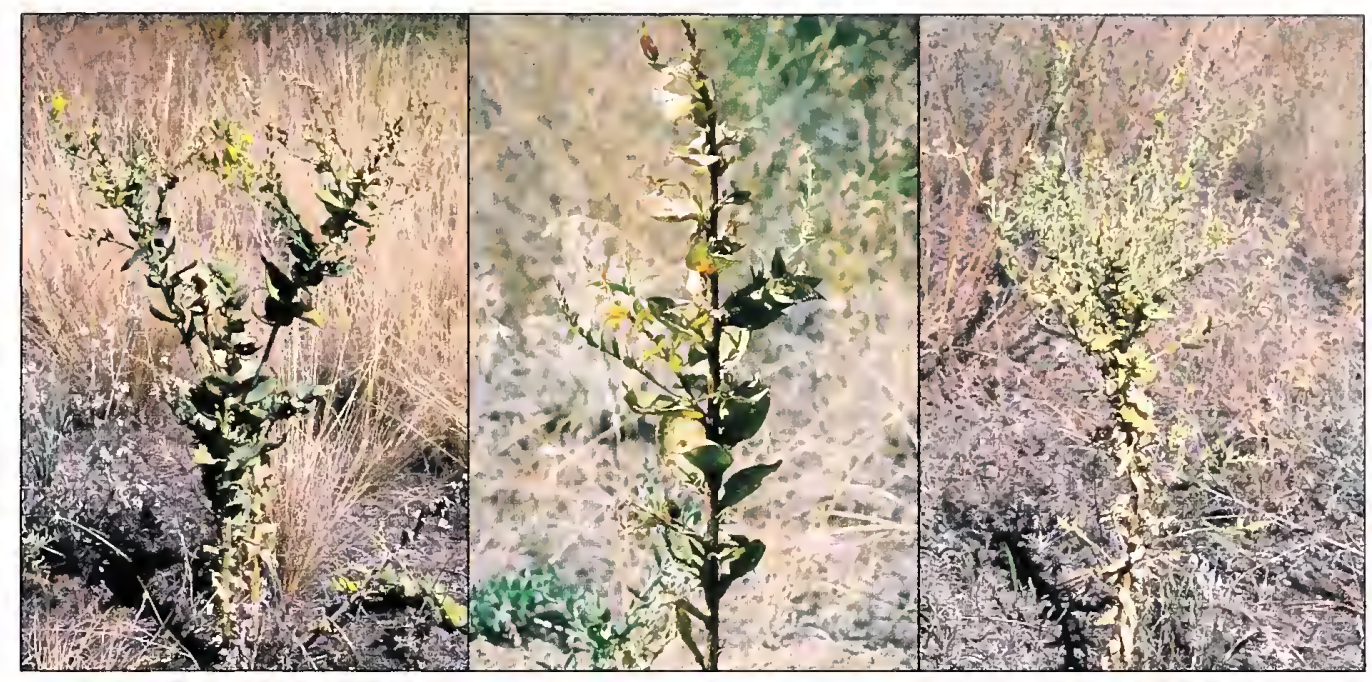

Figure 41. Dalmatian toadflax damaged by Mecinus janthinus. UGA1416040, UGA1416041, UGA 1416042

\section{Comments}

The toadflax stem-mining weevil is a strong flier and quickly disperses throughout toadflax-infested areas. Field observations indicate that the insect can spread over 2 $\mathrm{mi}(3 \mathrm{~km})$ in four years, and readily locates isolated toadflax plants and small populations.

The majority of releases of the stem-mining weevil have been against Dalmatian toadflax and are concentrated in the western states (Colorado, Idaho, Montana, North Dakota, Oregon, South Dakota, Utah, Washington, and Wyoming) and provinces (Alberta, British Columbia, and Saskatchewan), within hot, dry, forested areas or on rangeland supporting populations of large-stemmed toadflaxes. Dalmatian toadflax seems to be the preferred host, although the weevil was originally collected from and accepted yellow toadflax in feeding, oviposition, and development studies conducted in Europe. Establishment on yellow toadflax in the United States and Canada has been poor, although some weevil populations in British Columbia have attacked yellow toadflax after nearby Dalmatian toadflax populations severely declined from weevil damage. Studies are being conducted to determine why yellow toadflax is not a preferred host at sites where the stem-mining weevil has been released.

The overwintering of adults within dead Dalmatian toadflax stems, which typically stand above snow cover, exposes the weevils to ambient temperatures. Adult mortality can reach 75 to 100 percent where temperatures drop lower than $-18.5^{\circ} \mathrm{F}\left(-28^{\circ}\right.$ C); however, stem-mining weevil populations are capable of rebounding from injurious climatic episodes with time. Mortality of the weevil from other causes (e.g., parasitism) has been low to date. 


\section{Rhinusa antirrhini (Paykull) (formerly Gymnetron antirrhini)}

\section{Rhinusa neta (Germar) (formerly Gymnetron netum-see Note on page 43)}

Common name: Toadflax seed-feeding weevils

Order: Coleoptera

Family: Curculionidae

Two toadflax seed-feeding weevils were accidentally introduced into North America during the early $20^{\text {th }}$ century. Rhinusa antirrbini is native to Europe, North Africa, and western Asia, while $R$. neta is native to Europe and western Asia. R. antirrhini is widely distributed throughout North America, generally occurring wherever yellow toadflax is found.

$R$. antirrbini and $R$. neta readily attack yellow toadflax, and $R$. antirrbini is now found almost everywhere that yellow toadflax grows in North America. What was originally thought to be a biotype of $R$. antirrbini that prefers Dalmatian toadflax was introduced by Canada in 1993. However, recent molecular studies suggest that it is a separate Rhinusa species. R. neta is less common, and occurs in scattered populations in the eastern and western United States and Canada. It prefers yellow toadflax, although a less common Dalmatian toadflax biotype is known.

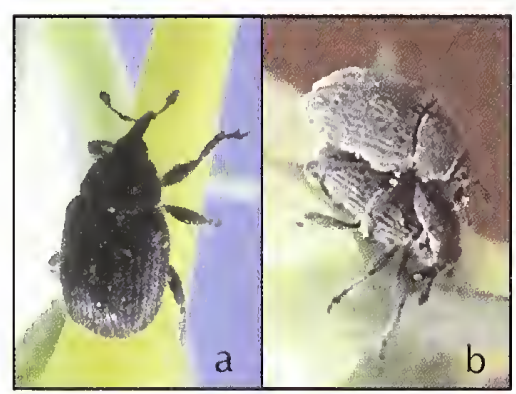

Figure 42. a) Rhinusa antirrhini and b) $R$. neta adults. UGA1416043, UGA 1416001

Adults of both species are small, oval weevils. $R$. antirrbini adults (Fig. 42a) are black, with a distinctly curved and pointed snout; they are typically 0.1 in $(2.5 \mathrm{~mm})$ or less in length. Adult $R$. neta weevils (Fig. 42b) are slightly larger that $R$. antirrbini adults, reaching a length of 0.12 in $(3 \mathrm{~mm})$. $R$. neta adults are grey or brown in color, with a snout that is somewhat blunt and only slightly curved.

Adults emerge in May and June from their overwintering sites in the soil and feed for a short time on toadflax leaf buds, young ieaves, and young shoot tips. Adults are fairly long-lived, surviving into

August. As the toadflax flowers begin to open, adults move into the blossoms to feed on pollen and floral tissues. After mating, the females start laying eggs into the floral ovaries. To oviposit, the female chews a small hole in the ovary wall, deposits one or more eggs, and then uses frass (excrement) to seal the hole. Females lay 40 to 50 eggs during their lifetime. Eggs hatch in about two weeks. Larvae are C-shaped, legless, about 0.15 in (4 mm) long, and creamy-yellow (Fig. 43). Mature $R$. antirrbini larvae have dark brown head capsules, while mature $R$. neta larvae have light brown head capsules.

An external and internal protuberance or spur (think of it as a nose growing on the outside of the seed capsule) appears just above oviposition sites on seed capsules containing $R$. antirrbini eggs. The spur pushes the egg deep among the developing 


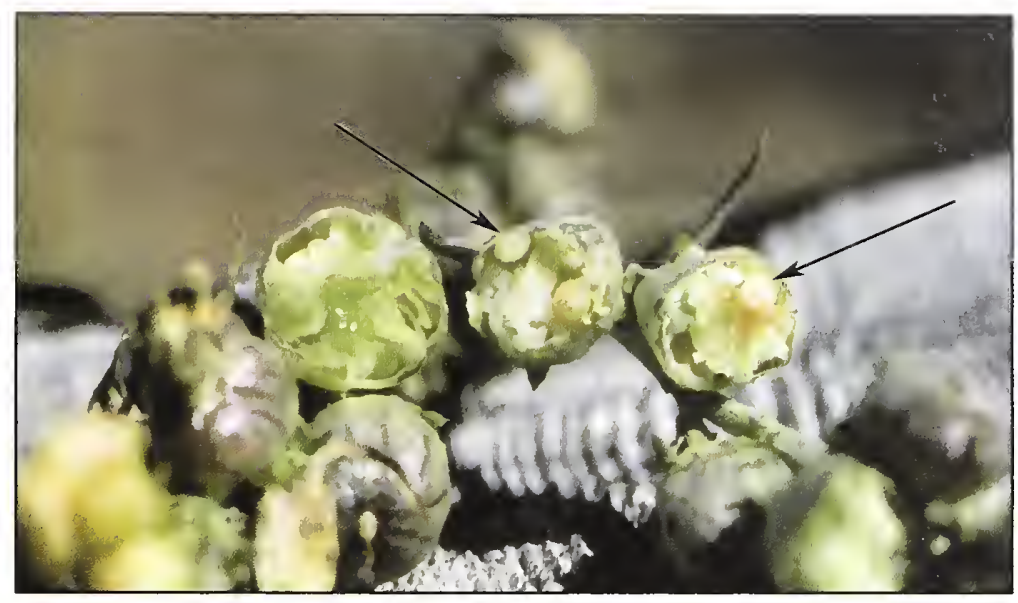

Figure 43. Rhinusa antirhini larvae feeding inside yellow toadflax seed capsules. UGA1416001

seeds, triggering the formation of a gall that causes the 8-12 seeds surrounding the egg to grow up to 10 times their normal size. The early instar larvae feed primarily on these pale, watery seeds, but older, later instar larvae also consume normal seeds. Capsules attacked by $R$. neta do not produce galls. Larvae of both species complete development in 20 to 30 days after undergoing three instars.

Mature Rhinusa larvae construct loose cells made from plant tissue fragments within the damaged toadflax capsules, and pupate inside these cells. Pupal development is completed in 10 to 15 days, and the new generation adults emerge in August and September. Thus, seed-feeding weevils complete their development to adulthood in 40 to 60 days. Newly-emerged adults may feed for a short time on toadflax stems before entering the soil to overwinter. Some late-developing adults may remain within the pupal cells in attacked toadflax seed capsules throughout the winter. Both species complete only one generation per year (Fig. 44).

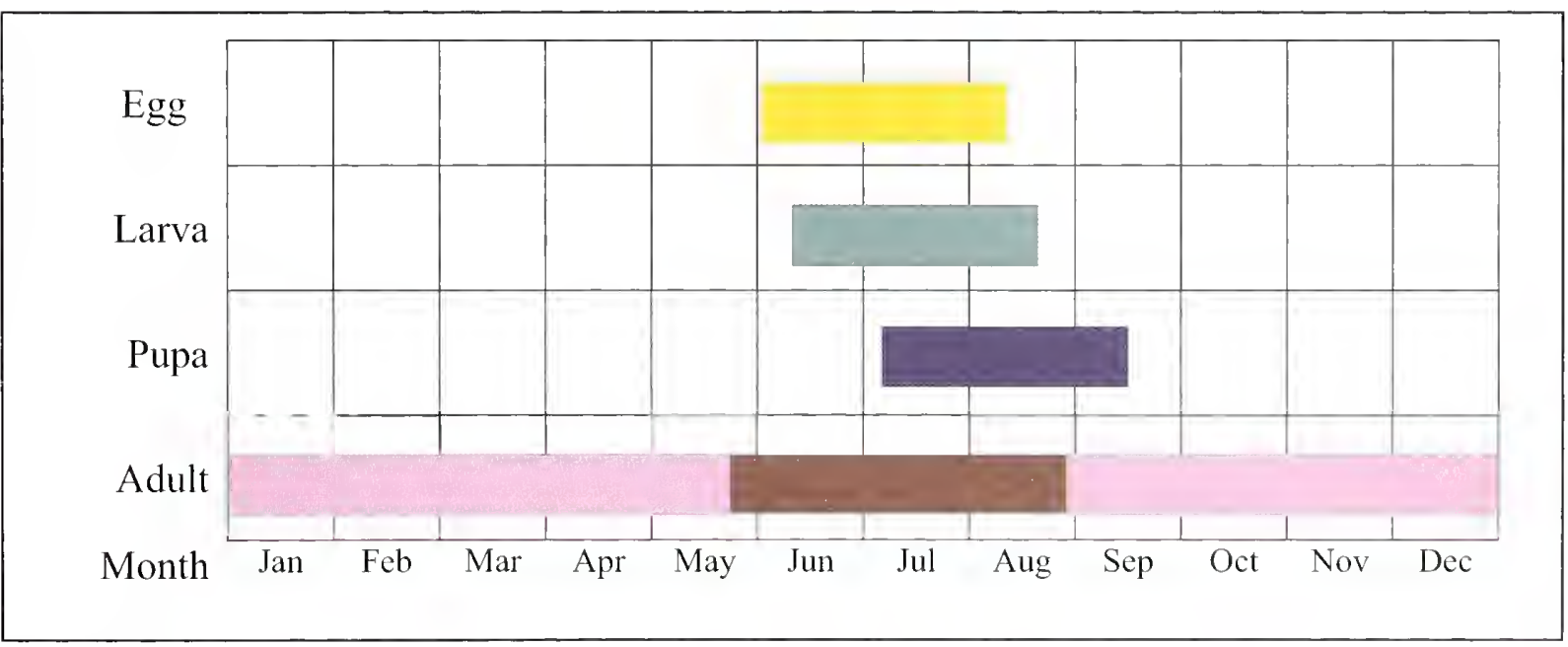

Figure 44. Schematic life cycle of Rhinusa antirrhini and $R$. neta. Colored bars indicate the approximate length of activity for each of the life stages. The light red bars represent the overwintering adult. 


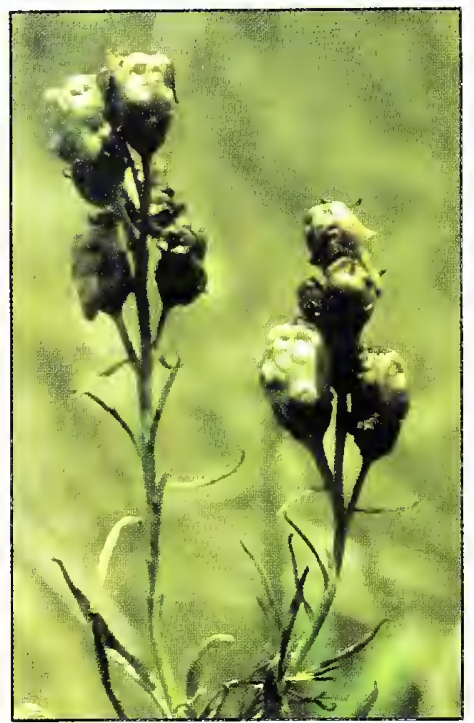

Figure 45. Swollen yellow toadflax seed capsules caused by Rhinusa antirhini attack. UGA1416046

\section{Host Specificity}

Although these weevils were initially inadvertently introduced, host-specific biotypes imported in the late 1990s underwent limited host-specificity screening in Europe prior to release in North America. Laboratory studies have shown that Rhinusa species can feed and complete development on a few closely-related Eurasian Linaria spp., as well as species in the plant genera Antirrbinum, Chaenorrbinum, and Kickxia. However, only Dalmatian and yellow toadflax are known to be attacked in the field.

\section{Impact}

Young toadflax seeds adjacent to each $R$. antirrbini egg exhibit abnormal development following oviposition, becoming swollen (up to 10 times normal size) and turning a watery, pale yellow color. As a result, attacked capsules can be easily identified (Fig. 45). It is unknown what causes seeds to swell, but it is likely a biochemical reaction by the plant to the eggs. Abnormal seeds are not viable, and larval feeding destroys additional seeds within infested capsules. While $R$. neta does not cause seed swelling, a single larva can consume a high proportion of the seeds in the host capsule. At high densities (more than two larvae per capsule) larvae of both species can destroy all viable seeds in an attacked capsule. 
The abundance and impact of the seed-feeding weevils seems limited by the flowerfeeding beetle. Apparently, flower-feeding larvae inside toadflax flowers will consume seed-feeding weevil eggs. At locations where the two biocontrol agents occur together, few seed-feeding larvae are found until August, when the flower-feeding beetle has completed its larval development. Together, the seed-feeding weevils and the flower-feeding beetle appear to have complementary effects in reducing yellow toadflax seed production; up to 90 percent destruction of yellow toadflax seed is possible when both species are present.

\section{Comments}

At least one parasitic wasp species has been reported to attack $R$. antirrbini in the United States.

Note: The seed-feeding weevils and the closely-related root-galling weevil (described in the following section), were formerly in the weevil genus Gymnetron. Recent studies conducted in Europe have reclassified all three weevils into the genus Rhinusa. We follow this current classification in this manual (numerous references to the former genus Gymnetron are given throughout the text). 


\section{Rhinusa linariae (Panzer) (formerly Gymnetron linariae)}

Common name: Toadflax root-galling weevil

Order: Coleoptera

Family: Curculionidae

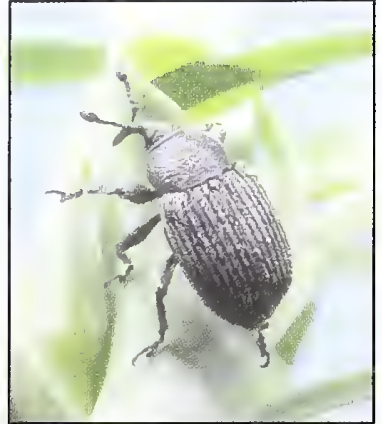

Figure 46. Adult Rhinusa linariae.

UGA1416047

Rhinusa linariae adults are small, black, somewhat ovalshaped weevils 0.1 in $(2.5 \mathrm{~mm})$ in length, with pronounced, curved snouts (Fig. 46). Rhinusa linariae is native throughout Europe and Russia It was approved for field release in the United States and Canada in 1995 for biocontrol of both Dalmatian and yellow toadflax. It was released in several western states and provinces, but only a few populations are known to have become established.

Overwintered adults begin to appear on toadflax plants in April, and feed for several weeks on stems, consuming stem tissue and sap. Adult weevils are generally present from May through July. Adult males are commonly observed on host plants, while the females apparently spend much of their time hidden in the soil near the roots. After mating, female weevils lay eggs singly into pockets they chew into toadflax roots, and then cover the hole with frass. Most eggs are laid in the root crown area, close to the soil surface.

Soon after oviposition, galls (abnormal root growths) begin to develop near the oviposition holes on the root (Fig. 47). Larvae hatch from eggs in 10 to 17 days, and root-galling larvae spend their entire life feeding and developing within the root galls. Larvae are C-shaped, about 0.15 in $(4 \mathrm{~mm})$ long, legless, cream-colored, with a brown head capsule. Larvae complete three instars in about 40 to 50 days, from midMay through late June.

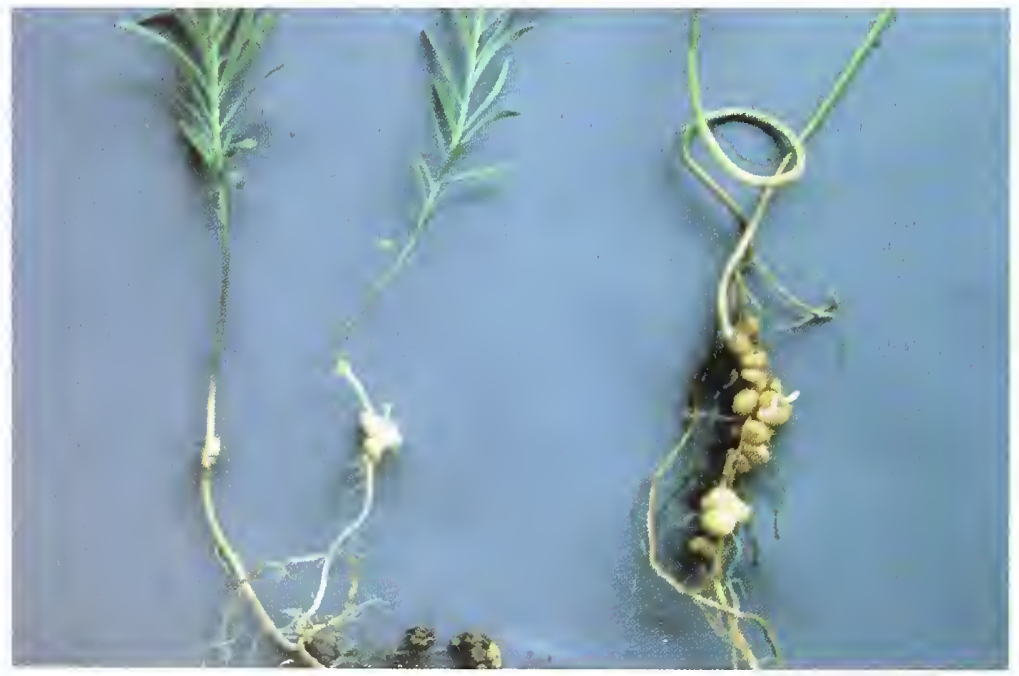

Figure 47. Toadflax root galls caused by Rhinusa linariae. UGA1416001 
Pupation occurs within the galls, and the pupal stage lasts about two weeks. Newlyemerged adults can be found beginning in mid-July. Development from egg to adult is completed in eight to 10 weeks. After a few weeks of feeding on toadflax stems, the adults return to the soil to overwinter. Some new, fully-developed adults remain within the root galls throughout the fall and winter, and do not emerge until the following spring. There is one generation a year for this weevil (Fig. 48).

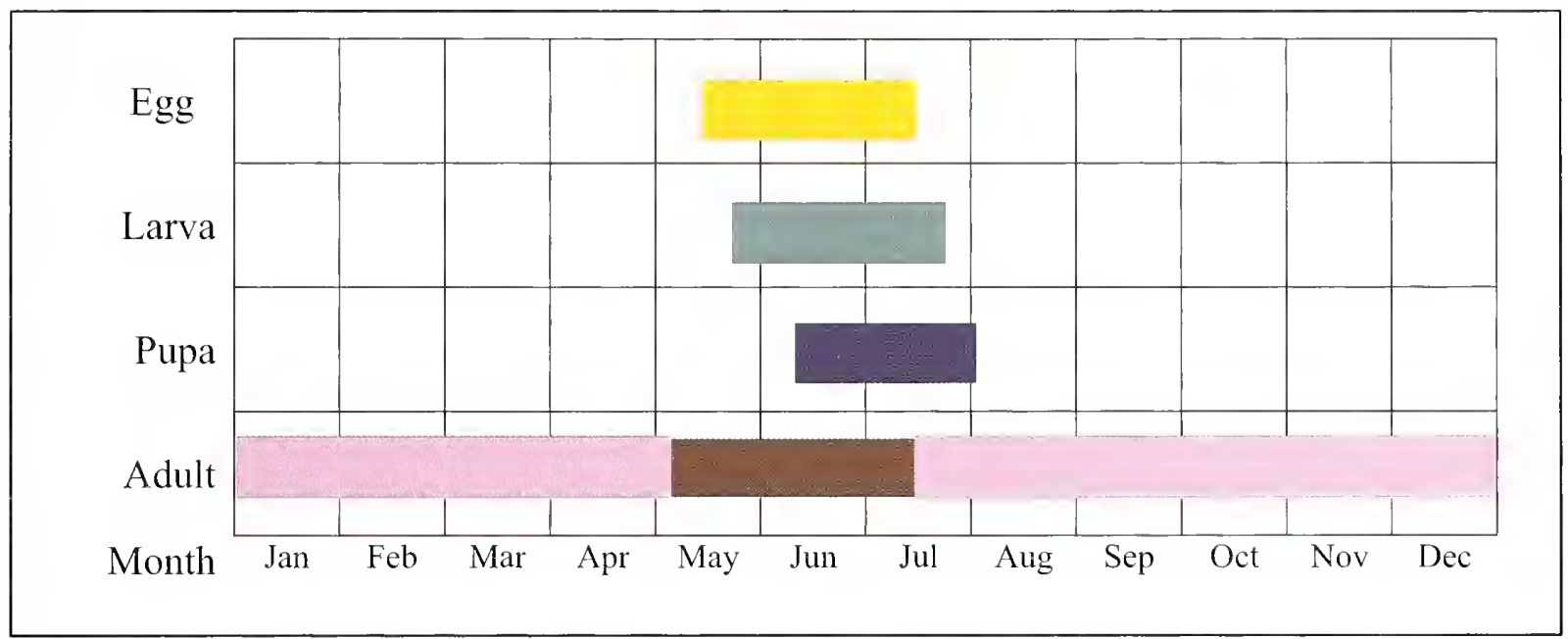

Figure 48. Schematic life cycle of Rhinusa linariae. Colored bars indicate the approximate length of activity for each of the life stages. The light red bars represent the overwintering adult.

\section{Host Specificity}

Experiments conducted in Europe have shown that the root-galling weevil has a narrow host range. In addition to Dalmatian and yellow toadflax, the weevil is able to feed, induce gall formation, and complete development only on a few closely-related toadflax species from Eurasia. No attack has been observed on plants in other genera.

\section{Impact}

The root-galling weevil appears capable of inducing gall formation on toadflax roots. It is uncertain what causes the galls to form, but their growth may be stimulated by larval or adult feeding, or both. Many eggs can be laid in a single root, and many galls can be found on a single toadflax root system. In European field studies, between 20 and 100 galls per plant were found on the roots of attacked yellow toadflax. Adjacent root galls can fuse into large masses of up to 40 individual galls.

The root galls disrupt the movement of nutrients and water to and from the roots. Galls may also act as a metabolic sink, causing the accumulation of nutrients in the roots to be used to form root galls, therefore robbing the toadflax plant of essential nutrients for normal plant growth. Although significant gall development can occur, it is not yet known what impact, if any, this agent is having on Dalmatian or yellow toadflax populations in the United States and Canada because of its poor establishment to date. 


\section{Comments}

Several small populations of the root-galling weevil are established in British Columbia. At present, it is not certain if the root-galling weevil has successfully established at release sites in Colorado, Montana, and Wyoming. Thus, the current and potential efficacy of the root-galling weevil in the United States and Canada cannot yet be determined. 


\section{SUMMARY OF CHAPTER 2}

Eight species of insects have been accidentally or intentionally introduced for biological control of toadflax in North America. For a quick reference, Table 4 compares the adult insects and their damage, and Table 5 compares the larvae and pupae of each species, and describes their damage. Figure 49 is a stylized drawing of toadflax showing which parts of the plant are attacked by each of the biocontrol agents.

Table 4. Comparison of adult toadflax biological control agents and their damage.

\begin{tabular}{|c|c|c|c|c|}
\hline Common Name & $\begin{array}{l}\text { Toadflax flower- } \\
\text { feeding beetle }\end{array}$ & $\begin{array}{l}\text { Toadflax defoliating } \\
\text { moth }\end{array}$ & $\begin{array}{l}\text { Toadflax root- } \\
\text { boring moth }\end{array}$ & $\begin{array}{l}\text { Yellow toadflax } \\
\text { root-boring moth }\end{array}$ \\
\hline Scientific Name & $\begin{array}{l}\text { Brachypterolus } \\
\text { pulicarius }\end{array}$ & Calophasia lunula & $\begin{array}{l}\text { Eteobalea } \\
\text { intermediella }\end{array}$ & Eteobalea serratella \\
\hline Adult Description & $\begin{array}{l}\text { Dark brown to black, } \\
\text { oval beetles } 0.12 \text { in }(3 \\
\mathrm{mm}) \text { long }\end{array}$ & $\begin{array}{l}\text { Mottled grey-brown, } \\
\text { with light and dark } \\
\text { markings on the wing, } \\
0.4 \text { to } 0.6 \text { in (10-15 } \\
\text { mm) long, wingspan } 1 \\
\text { to } 1.2 \text { in ( } 25.4-30.5 \\
\mathrm{~mm})\end{array}$ & \multicolumn{2}{|c|}{$\begin{array}{l}\text { Black with white and gold spots, slender, } 0.3 \text { to } \\
0.4 \text { in }(7.5-10 \mathrm{~mm}) \text { long, with a wingspan of } \\
0.6 \text { to } 0.7 \text { in }(15-18 \mathrm{~mm})\end{array}$} \\
\hline $\begin{array}{l}\text { Generations } \\
\text { Per Year }\end{array}$ & One & $\begin{array}{l}\text { One or two } \\
\text { (rarely three) }\end{array}$ & Two & One \\
\hline Eggs & $\begin{array}{l}\text { Eggs are first milky } \\
\text { white, later turning } \\
\text { yellow, laid singly } \\
\text { under petals in } \\
\text { unopened flower bud }\end{array}$ & $\begin{array}{l}\text { Eggs are ribbed and } \\
\text { cream-colored, laid } \\
\text { singly on foliage and } \\
\text { flowers }\end{array}$ & \multicolumn{2}{|c|}{$\begin{array}{l}\text { Eggs are cream-colored, laid in loose strings of } \\
3-8 \text { on base on stem, or on the soil surface }\end{array}$} \\
\hline Damage & $\begin{array}{l}\text { Adults feed on young } \\
\text { shoot tips, flower buds } \\
\text { and pollen }\end{array}$ & $\begin{array}{l}\text { Adults consume } \\
\text { flower nectar and may } \\
\text { pollinate plant }\end{array}$ & \multicolumn{2}{|c|}{ Adults do not feed } \\
\hline
\end{tabular}


Table 4. Comparison of adult toadflax biological control agents and their damage (continued).

\begin{tabular}{|c|c|c|c|c|}
\hline Common name & $\begin{array}{l}\text { Toadflax stem- } \\
\text { mining weevil }\end{array}$ & $\begin{array}{l}\text { Toadflax seed- } \\
\text { feeding weevil }\end{array}$ & $\begin{array}{l}\text { Toadflax seed- } \\
\text { feeding weevil }\end{array}$ & $\begin{array}{l}\text { Toadflax root- } \\
\text { galling weevil }\end{array}$ \\
\hline Scientific Name & Mecinus janthinus & Rhinusa antirrhini * & Rhinusa neta * & Rhinusa linariae * \\
\hline Adult Description & $\begin{array}{l}\text { Elongate, elliptical, } \\
\text { bluish-black, with a } \\
\text { large snout, } 0.2 \text { in ( } 5 \\
\mathrm{~mm} \text { ) long }\end{array}$ & $\begin{array}{l}\text { Oval, black, with a } \\
\text { pointed, curved snout, } \\
0.1 \text { in }(2.5 \mathrm{~mm}) \text { long }\end{array}$ & $\begin{array}{l}\text { Oval, grey-brown, } \\
\text { with a blunt, slightly } \\
\text { curved snout, } 0.12 \text { in } \\
(3 \mathrm{~mm}) \text { long }\end{array}$ & $\begin{array}{l}\text { Oval, black, with a } \\
\text { pronounced, curved } \\
\text { snout, } 0.1 \text { in }(2.5 \mathrm{~mm}) \\
\text { long }\end{array}$ \\
\hline $\begin{array}{l}\text { Generations } \\
\text { Per Year }\end{array}$ & One & One & One & One \\
\hline Eggs & $\begin{array}{l}\text { Laid singly inside hole } \\
\text { in stem }\end{array}$ & \multicolumn{2}{|c|}{ Laid singly into floral ovary } & $\begin{array}{l}\text { Laid singly inside hole } \\
\text { in root }\end{array}$ \\
\hline Damage & $\begin{array}{l}\text { Adults feed on foliage } \\
\text { and stem tissue }\end{array}$ & \multicolumn{2}{|c|}{$\begin{array}{l}\text { Adults feed on leaf buds, young leaves, young } \\
\text { shoot tips, pollen, and nectar }\end{array}$} & $\begin{array}{l}\text { Adults feed on young } \\
\text { foliage and stem tissue }\end{array}$ \\
\hline
\end{tabular}

\footnotetext{
* formerly Gymnetron
} 
Table 5. Comparison of larvae and pupae of toadflax biocontrol agents and their damage

\section{Common Name}

Scientific Name

Toadflax flower-feeding beetle Brachypterolus pulicarius

Toadflax defoliating moth Calophasia lunula

Toadflax root-boring moth Eteobalea intermediella Yellow toadflax root-boring moth E. serratella

Toadflax stem-mining weevil Mecinus janthinus

Toadflax seed-feeding weevils Rhinusa antirrhini* and R. neta*

Toadflax root-galling weevil Rhinusa linariae*

\section{Description of and Damage Caused by Larvae}

Larva is yellow, 0.3 in $(7.5 \mathrm{~mm})$ in length, with a dark head capsule that lightens over time; feeds in unopened flowers on pollen and developing ovary, pupates in the soil. Larval feeding limits flowering and seed production.

Larva is a brightly-colored caterpillar, 1.5 to 1.8 in $(3.8-4.6 \mathrm{~cm})$ long, consumes foliage, pupates in cocoon at base of plant. Larval defoliation weakens plant.

Larvae are cream-colored caterpillars with brown head capsules, and 0.5 in (12.5 $\mathrm{mm}$ ) long. They feed on cortex tissue in the toadflax root. Larval feeding damage can reduce plant vigor and seed production.

Larvae are C-shaped, creamy-white, with light brown head capsule, legless, 0.2 in (5 $\mathrm{mm}$ ) long; feed on tissue inside stem, pupate inside hollowed stem. Larval feeding can reduce flowering and seed production, and shoot biomass. Severe damage can result in stem, or even plant death.

Larva is C-shaped, 0.15 in (4 mm) long, creamy-yellow, legless, with a tan head capsule; feeds in capsule on developing seeds, pupates inside hollowed capsule. Larval damage reduces seed production.

Larva is C-shaped, 0.15 in (4 mm) long, cream-colored, legless, with a brown head capsule; feeds on tissue inside the root gall, pupates inside root gall. Galls and larval feeding deplete roots of nutrients and water.

* formerly Gymnetron 


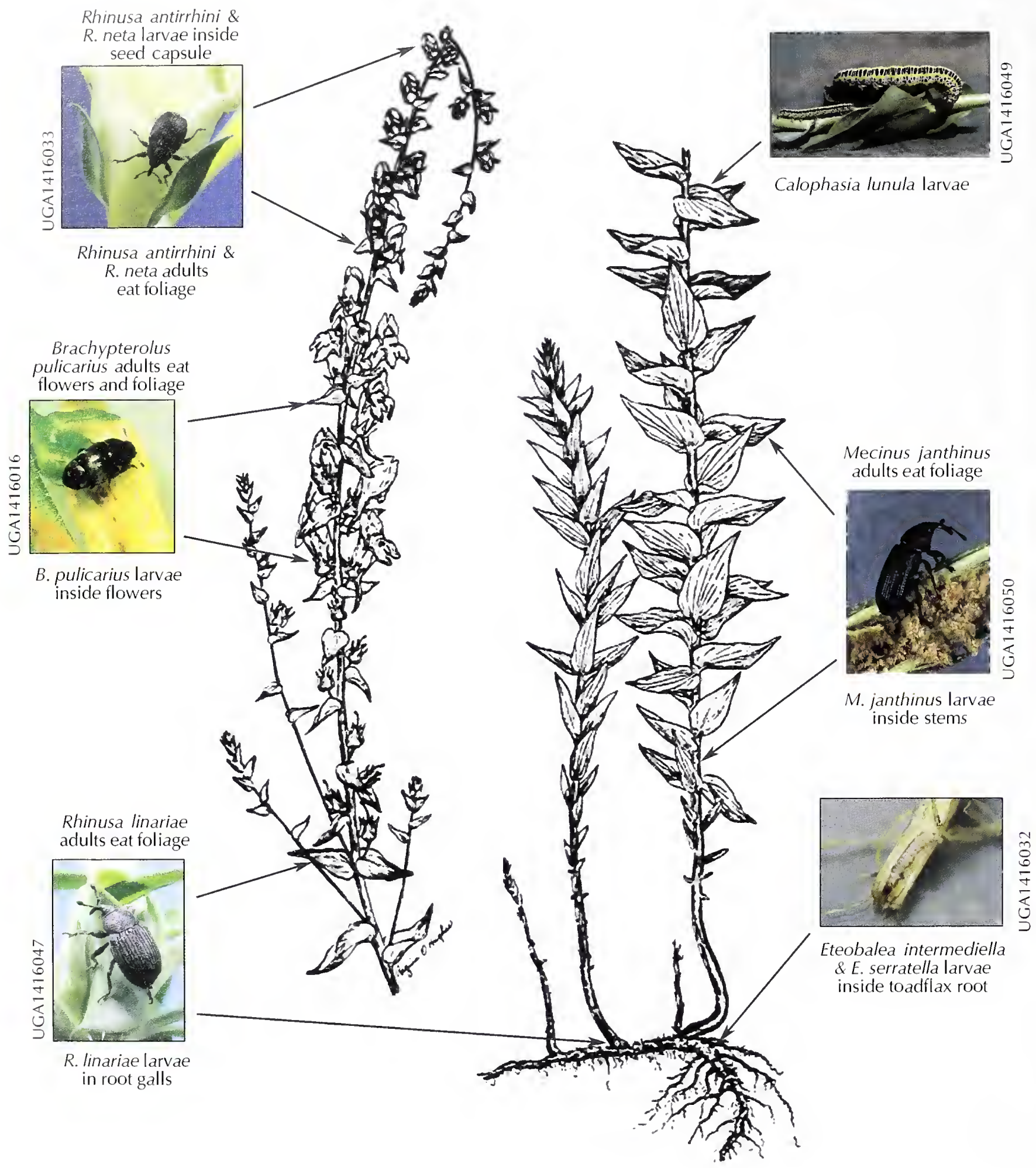

Figure 49. Generalized drawing of toadflax, indicating its biocontrol agents and the plant parts they attack. Note: Most insects attack both Dalmatian and yellow toadflax. Biotypes of the weevil, Rhinusa spp., occur on either Dalmatian or yellow toadflax; the root-boring moth, E. serratella, occurs on yellow toadflax only. 


\section{CHAPTER 3}

\section{DEVELOPING, IMPLEMENTING, AND MANAGING A TOADFLAX BIOLOGICAL CONTROL PROGRAM}

The first and most important step in developing a program is to clearly define your goals and objectives. With clearly defined objectives, it is possible to properly plan and implement a program. Considerations in planning your toadflax biocontrol program include selecting release sites, obtaining and releasing insects, and monitoring the success of the program. This chapter includes six sections:

1. Planning a toadflax biocontrol program

2. Deciding what biocontrol agent(s) to release

3. Selecting release sites

4. Obtaining toadflax biocontrol agents

5. Handling and releasing toadflax biocontrol agents

6. Monitoring the biocontrol agents, toadflax, and other vegetation

By knowing your goals and objectives before making your initial release, you will be able to develop efficient, cost-effective strategies to evaluate the success of your program. Programs are evaluated by monitoring the toadflax biocontrol agents and the toadflax population over time. Regular monitoring determines 1) if the agents successfully established at a site, 2) if agent populations have increased and spread over time, 3) how damage by the agents has impacted toadflax over time, 4) how other plants in the community have responded to weed suppression, and 5) what impact, if any, biocontrol agents had on nontarget plants. Examples and suggestions of protocols to plan, develop, implement, and monitor a toadflax biocontrol program are outlined in this chapter. A troubleshooting guide for solutions to commonly encountered problems is provided in Appendix B. 


\section{Planning a Toadflax Biocontrol Program}

Careful planning is important before you begin implementing a toadflax biocontrol program. Setting biocontrol program goals and understanding what is involved in implementing and managing a toadflax biocontrol program increases the probability of its success. The following elements are important components of pre-implementation planning.

a) Assess the current status of toadflax in your management area and adjacent ownerships:

- Develop a distribution map for each toadflax species in your management area. This map will be useful for all your weed management activities and will enable you to better identify areas of infestation that are suitable for biological control.

- Review other management strategies used against Dalmatian and yellow toadflax and assess their results.

- Consult with your agency or university biocontrol expert, cooperative weed management area representative (CWMA), or county weed coordinator/ supervisor to become familiar with other toadflax management activities that are underway or are being planned in your area, especially herbicide or mowing programs that may have a direct impact on your proposed biocontrol program.

b) Define the goals of your program:

- Outline the weed management objective(s) for your management area and how these objectives fit into the long-term land use goals for the toadflax-infested area.

- Consider if biological control is an appropriate strategy for the targeted management area. If you want to eradicate toadflax from your area, then biocontrol is not appropriate. However, if your objective is to reduce toadflax cover, flowering and seed production, and promote the growth of desirable vegetation, then a biocontrol program may be compatible with your management objectives.

- Consider the projected life span of the program. Many biocontrol programs do not show results for a number of years (3-5 years or longer). Make sure that you can make a long-term commitment to the program.

- Discuss your program plans with neighboring landowners/managers or CWMAs.

c) Establish support logistics:

- Commit resources for field equipment and supplies (if needed).

- Recruit and train personnel.

- Identify sources of biocontrol agents.

- Outline and prepare a plan to document yearly activities. 


\section{Deciding What Biocontrol Agent(s) to Release}

As described in Chapter 2, there are eight species of insects released or established for toadflax biological control. However, not all the biocontrol agents perform equally. We developed a subjective scoring system to provide land managers with additional information that they can use when deciding what biocontrol agents to release. The scoring system rates each biocontrol agent on three criteria; specificity to the target host plant, weed control efficacy, and current (2005) availability. The ratings described below are based on our current understanding of the biocontrol agents, and may change over time as we learn more about how each of the biocontrol agents performs in the field.

a. Efficacy: Efficacy is a measure of the biocontrol agent's ability to control toadflax. The effectiveness of each biocontrol agent is not completely known at this time. This is because neither field observations nor experimental studies have been conducted for a sufficiently long period of time to be able to fully predict each agent's effectiveness in all situations or habitats. Based on our current knowledge, this is a qualitative rating of each toadflax biocontrol agent for both Dalmatian and yellow toadflax.

b. Specificity: Another consideration when selecting biocontrol agents is their specificity to the target weed. Specificity can be used as a measure of the amount of risk that a biocontrol agent presents to other plant species (nontarget plant species). The safest insects are those that are the most host specific, attacking only toadflax and no other plant species. For example, there is significant evidence that the larvae of the defoliating moth attacks plants other than toadflaxe.g., common snapdragon and other plant species related to yellow and Dalmatian toadflax. The defoliating moth, therefore, poses a risk to nontarget plants. For this reason, many agencies and land managers have ceased releasing or redistributing the defoliating moth. The specificity ratings we provide here for each biocontrol agent are based on our current knowledge.

c. Availability: Some toadflax biocontrol agents are more abundant and available than others-e.g., the flower-feeding beetle is widespread while the root-galling weevil is very restricted in availability. Moreover, some biocontrol agents may be more abundant on one species of toadflax than another-e.g., the flower-feeding beetle is more abundant on yellow toadflax than on Dalmatian toadflax.

Chart 1 illustrates our current understanding of the relative host specificity, weed control efficacy, and abundance for each biocontrol agent on Dalmatian and yellow toadflax. The colored circle in the uppermost right hand corner of the chart would correspond to the most host-specific and effective toadflax biocontrol control agent. The agent with the largest circle is the most abundant (as of 2005). For Dalmatian toadflax, the agent with the highest performance rating is the stem-mining weevil (indicated in blue). While it is considered less host specific than either the root-boring moths (indicated in red) or the root-galling weevil (indicated in yellow), the stemmining weevil is available and has proven to be effective at controlling Dalmatian toadflax. The agent with the lowest rating (closest to the lower left-hand corner) is the defoliating moth (indicated in green). The defoliating moth is abundant (indicated 
by a large circle), but is not considered effective at controlling toadflax infestations and it poses a known risk to some nontarget plants. For these reasons, we do not recommend releasing the defoliating moth. This diagram also illustrates that, at present, there does not appear to be a single most effective, safe, and readily-available biological control agent for yellow toadflax.

Chart 1. Predicted performance ratings for toadflax biocontrol agents.

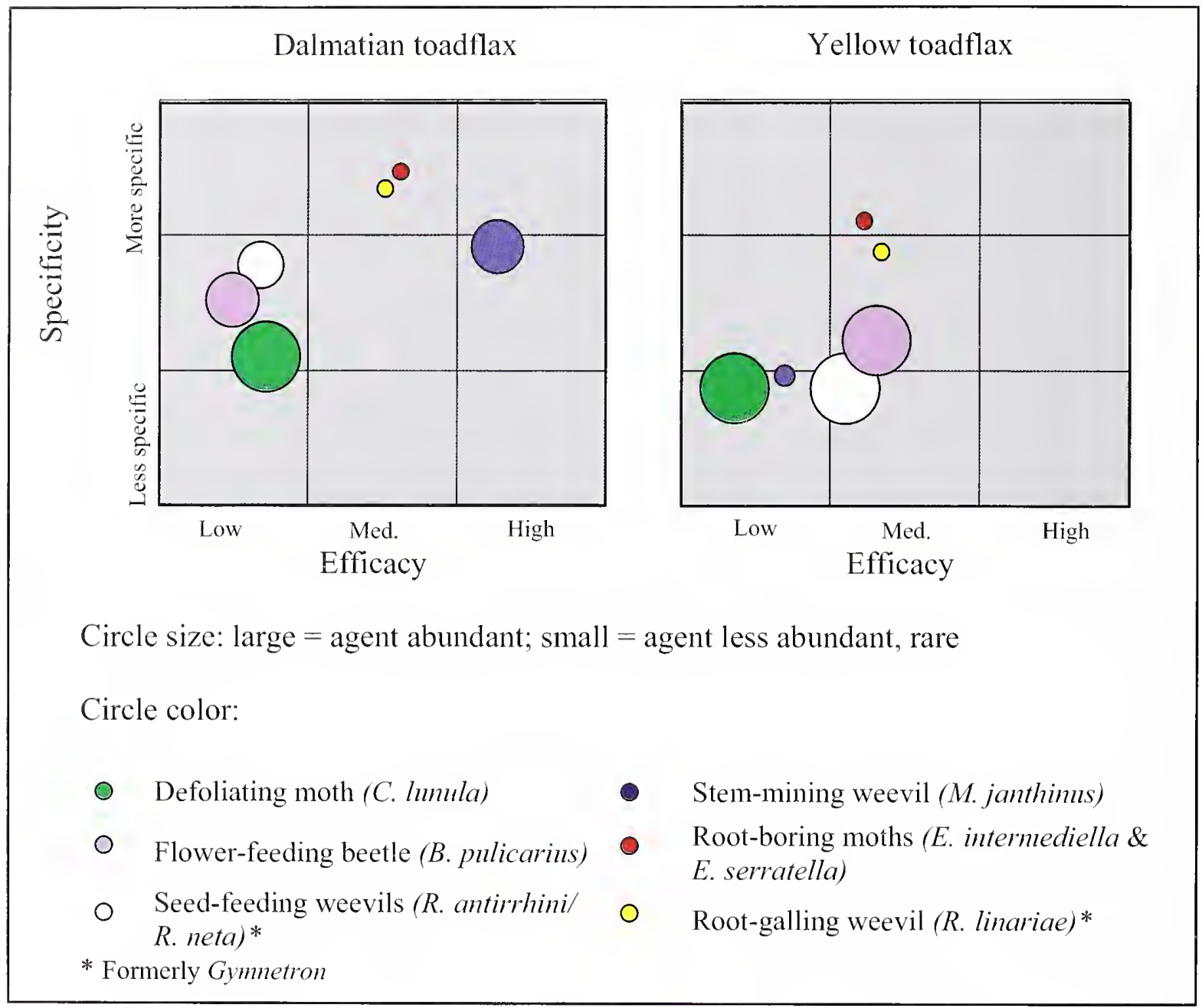

\section{Selecting Release Sites}

The sites that you select for releasing biocontrol agents should be carefully chosen to meet the primary goal(s) of your program. Consider the following points when selecting release sites:

- Sites selected to function as future collection and redistribution sites (typically called field insectaries or nursery sites) should be large-ideally, greater than 10 acres ( 4 ha) - have a fairly contiguous distribution of toadflax, be safe from disturbance or vandalism, and should be accessible for regular monitoring and collection activities. These sites can also serve as demonstration areas for educa- 
tional and training purposes, and generally should be kept separate from designated research sites.

- Sites intended for long-term insect and vegetation monitoring or research should be safe from interference by other weed management programs and disturbance, including grazing. A long-term commitment (10 years or longer) from the landowner or land management agency is ideal to adequately monitor progress and control. Collection of biocontrol agents from these sites should be restricted in order to track the growth of insect populations and evaluate their impact.

- Sites not intended to serve as field insectaries or long-term monitoring require fewer considerations. These general release sites should be suitable for biocontrol (sufficiently large and disturbance-free) to give the biocontrol agents the best possible chance to survive and flourish.

Visit several prospective release sites. Use the following guidelines and criteria to select sites:

Site factors. An infestation covering a minimum of 1 acre $(0.4 \mathrm{ha})$ in size is recommended, but a larger infestation of 5 acres $(2.1 \mathrm{ha})$ or more, such as that shown in Fig. 50 , is ideal. Sites that are in full sunlight are preferable, except by the flower-feeding beetle and the stem-mining weevil, which do much better on sites where some of the toadflax is at least partially shaded by other vegetation. The defoliating moth prefers sites that are more sparsely infested, and does not perform well on dense monocultures of toadflax. Avoid sites that are frequently disturbed (e.g., heavily grazed), where other weed control methods (mowing/cutting, burning) are planned, or near croplands where pesticides are used frequently and can drift onto the site.

Presence of biocontrol agents. Make sure you are aware of, and coordinate with, other biocontrol activities in your area. Check to see what biocontrol agents are already present at your planned release site. For example, the flower-feeding beetle, the defoliating moth, and the seed-feeding weevils are very abundant and widely distributed; thus, they may already be present at your site. By knowing which agents are already present at your site, you can focus on releasing complimentary agentsthose that will work with the existing agents to more efficiently control the target weed. For example, stem-mining weevil and flower-feeding beetles at a site are complementary agents. However, if you want to establish a field insectary of the seed-feeding weevils, avoid sites where the flower-feeding beetle is established, as these biocontrol agents compete for flower resources.

Ownership. The landowner must be willing to allow you to make releases and monitor them over several years. When obtaining permission to use a site, be sure to secure the following: 1) written permission from the landowner or land manager allowing use of the area as a release site, 2) written agreement from the landowner allowing access to the site for monitoring and collection for a period of at least 10 years, and 3) permission to install a permanent location marker at the site. 


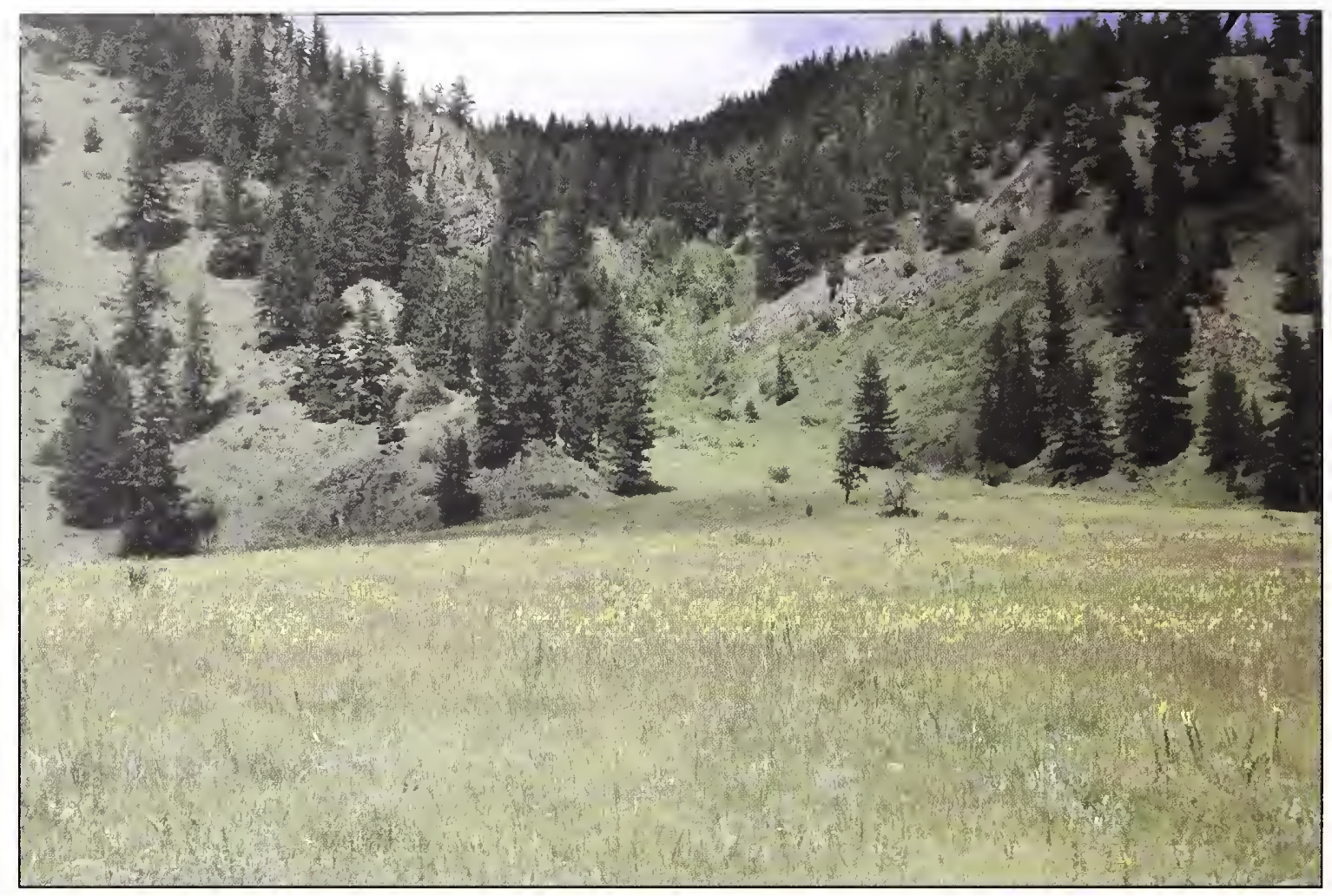

Figure 50. Example of a suitable release site for most toadflax biocontrol agents.

Establish a permanent location marker. After selecting a site, place a brightly colored marker in the infestation (plastic or metal stakes are preferred, as wooden stakes may decay over time). Ideally, the stake must be tall-about $6 \mathrm{ft}(2 \mathrm{~m})$ - and clearly visible to mark the exact location of the release site. Inform the landowner of the precise location of the marker to guard against any chance of its premature removal or destruction. Record the legal description of the release location and, if possible, use GPS to record the latitude and longitude or U'T'M coordinates at the marker.

Establish a photo point. Photographs taken annually from the same location can effectively illustrate the success of your biocontrol program over time. Refer to Section 5.3 for instructions on establishing a photo point.

Prepare a map. Generating a map of the infestation is helpful to visually assess the size and distribution of toadflax at the site before biocontrol agents are released. A detailed map and written directions to the release site are essential for you and others to locate the site after the release has been made. Note permanent roads, creeks, rivers, mile markers, etc., on the map and indicate the cardinal directions (N, S, E, W). If possible, include a legal description or use GPS to record the latitude and longitude or UTM coordinates so that the site can be easily located. Be careful of using natural markers such as trees or shrubs as they can die or be removed at any time. 
Monitor baseline vegetation. It is highly recommended that you assess the kind and amount of toadflax and other vegetation at the site before releasing biocontrol agents. Pre-release monitoring provides baseline data, allows meaningful before-and-after comparisons to be made, and provides important information on the effectiveness of the biological control program (see section 5 for information on vegetation monitoring).

\section{Obtaining Toadflax Biocontrol Agents}

Biocontrol insects are obtained either by collecting them yourself or with cooperator assistance from a designated and approved collection site, or purchasing them from a commercial supplier. Consider the following when planning your toadflax biocontrol program:

- Directly collecting biocontrol agents from established field populations provides robust and healthy insects. Obtaining adult insects soon after they emerge from overwintering sites and begin to mate will allow you to release individuals with maximum reproductive potential. If a cooperator is collecting the insects for you, be sure he/she collects the agents at the right time of year and under the best conditions, and that you are sent parasite- and pathogen-free, sorted insects (no other organisms in the containers) as soon as possible. Be sure cooperators know well in advance when you need the biocontrol agents for release, and that you will schedule your activities according to the agents' estimated time of arrival.

- Be sure that you know what agents you already have at the planned release site(s).

- Not all the biocontrol agents are equally available. For example, the root-boring moths are not available because they are not known to be established in North America. Likewise, the root-galling weevil is not currently available because, even though it is established in British Columbia and possibly at a few locations in the United States, the population levels are still low and not collectable. Other agents, such as the seed-feeding weevils, the flower-feeding beetle, and the defoliating moth are widely established and possibly may be already present at your site.

- Local sources of agents are always preferable because these insects are better adapted to the elevation, climate, and field conditions at your release site. Avoid purchasing agents from a supplier who collects agents from an environment significantly different from your planned release location.

- Commercial suppliers provide parasite- and pathogen-free, healthy insects. However, purchasing the insects can be expensive-some suppliers charge between $\$ 0.70$ to $\$ 0.90$ or more per insect. See section 4.2 for further guidelines.

- If your agents are being shipped to you from another state, the recipient must have a USDA-APHIS-PPQ permit (Form 526). For further information and to apply for a permit, visit the APHIS-PPQ website, http://www.aphis.usda.gov/ ppq/permits/biological/weedbio.html. 


\subsection{Collecting toadflax biocontrol agents}

This section provides information on collecting and purchasing toadflax biocontrol agents. Planning your collecting activity is important: learn how to recognize and identify the biocontrol agents, schedule the appropriate collecting time, prepare equipment and supplies, and train personnel in identification and collection techniques. Follow these general guidelines when planning your collection activities:

\section{Supplies Needed}

- Sturdy, breathable containers

- Masking tape

- Paper towelling or styrofoam (for transporting)

- Cooler

- Frozen ice packs

- Cardboard box (for shipping)

Containers. Collection containers must provide a safe and stress-free environment for the insects while preventing their escape. Use sturdy, breathable containers that allow air flow and will not collect condensation. An example of a good type of collection container is a pint-sized, nonwaxed, paperboard carton (Fig. 51). Plastic containers also can work well if a large hole has been cut in the lid and the hole is covered with mesh or organdy to allow airflow into the container and minimize the buildup of condensation. Glass or metal containers are generally not suitable. To prepare the containers, loosely place leafy toadflax stem pieces in the container. This provides shelter, food, and the right amount of moisture to keep your insects alive and healthy. To prevent weed spread, keep toadflax and other weed flowers or seeds out of the container. Do not put water in the container as insects could drown in it. After insects are collected in the field, transfer them as soon as possible into your breathable, durable containers. Keep containers shaded and cool at all times while collecting, sorting, counting, and transporting the biocontrol agents. Bring a large cooler with pre-frozen ice packs to the field, and tape the ice packs to the interior side of the cooler and surround the packs with crumpled newspaper so that they do not roll around or come into direct contact with the insect containers.

Collecting Methods. Tray sampling, sweep net, and aspiration are three commonly used methods to collect toadflax biocontrol agents. The most appropriate method will depend on the physical characteristics of the insect, the density of the insect population, available time, and available personnel. 


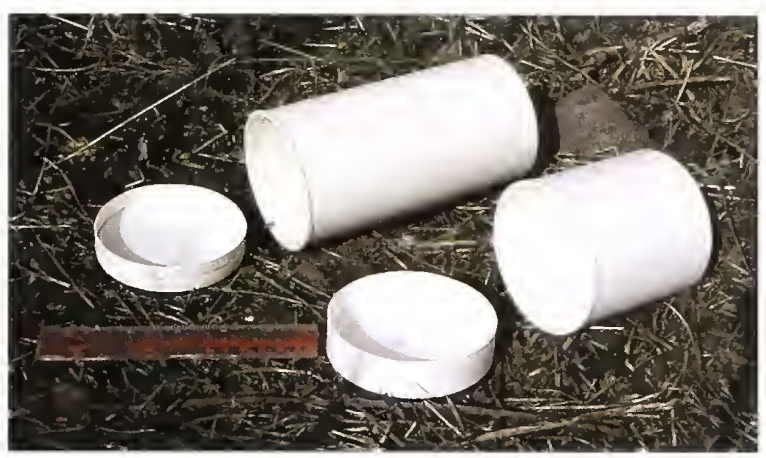

Figure 51. Unwaxed paperboard containers used to transport and ship biocontrol agents.

- Tray sampling. The tray sampling method is an efficient and productive way to collect adult beetles (B. pulicarius, $M$. janthinus, and Rbinusa spp.) when their populations are high. It is used to gather large numbers of beetles in a short amount of time. With the container held beneath the insects, use your hand or a short stick to tap the plant, knocking the beetles from the plant into a plastic tray or tub (Fig. 52) or into a plastic cup (Fig. 53). Approach plants carefully, as beetles often drop from the plants when they sense the presence of potential predators. Cover the tub or cup to prevent escape and sort the agents prior to shipping (see below).

- Sweep net. A sweep net is made of a sturdy, canvas or mesh bag on a hoop, about 15 inches $(38 \mathrm{~cm})$ in diameter, attached to a handle 3 feet $(0.9 \mathrm{~m})$ long (Fig. 54). As its name implies, it is generally used to "sweep" adult insects off a plant (e.g., sweeping is used to collect adult root-boring moths) (Fig. 55). It is important to gently sweep the plants, as vigorous sweeping of toadflax plants can damage the stems, and a significant amount of unwanted material (e.g., other insects, spiders, and plant material) can be collected along with the biocontrol agents. Do not use fine-gauze aerial or "butterfly" nets to collect beetles as they often snag and tear on vegetation (though butterfly nets can be used to collect adult root-boring moths).

- Aspirator: An aspirator is a device used to suck insects from a surface into a collection vial. It is used to collect insects out of a sweep net or tub, but can also be used to gather insects directly from the plant. Aspirating is easy and selective, and is the preferred method to sort insects after collection. Aspirators can be the manual, sucking type (Fig. 56a), or the gasoline or battery-powered, hand-held, vacuum type (Fig. 56b).

Sorting. Tray-sampling and sweep-netting are not selective collection methods, so other insects and spiders are usually collected along with the biocontrol agents. Sorting separates the biocontrol agents from unwanted insects, other organisms, and debris, such as weed seeds that have been collected along with the agents. The easiest way to sort is to empty the contents of the net or plastic cup into a plastic tub (Fig. 57) and aspirate the toadflax agents out of the debris. If the collected material is first chilled in a cooler, the insects will move more slowly and will be easier to catch and sort. Use an aspirator (described above) to sort the beetles (Fig. 58). Chilled insects, particularly stem-mining weevil adults, may also be gently collected from a tray with a pair of flexible forceps. 


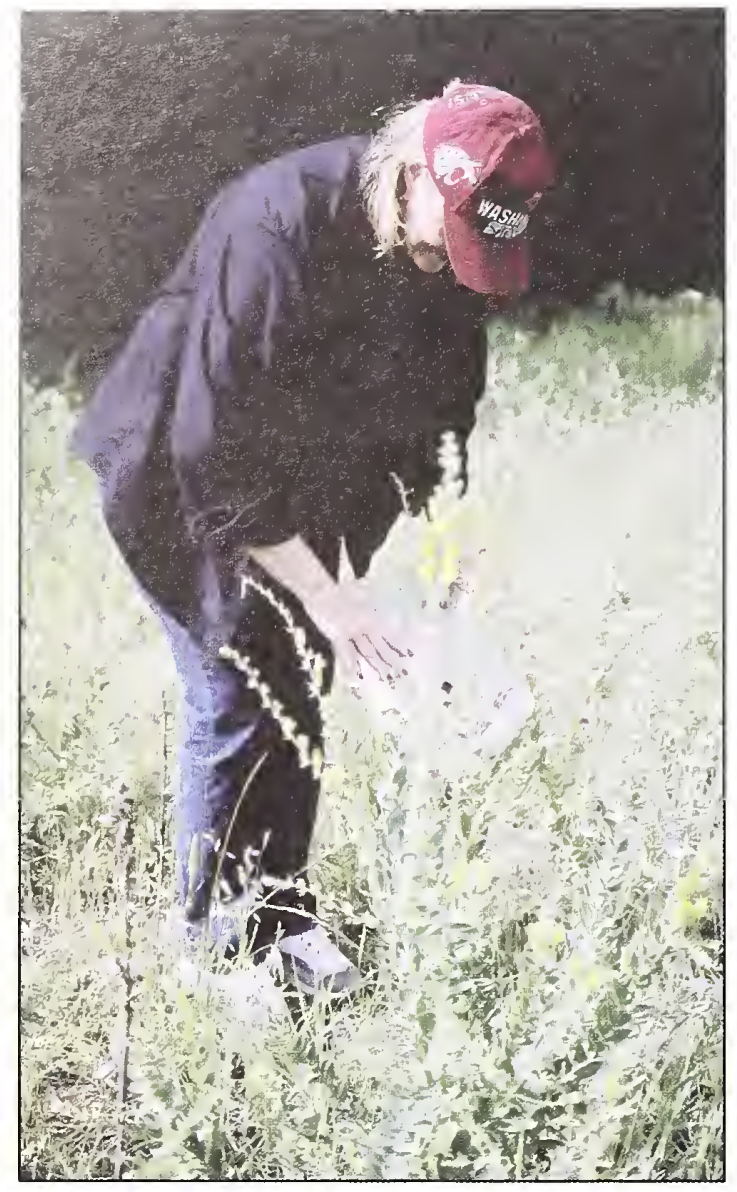

Figure 52. Collecting Mecinus janthinus using the tray sampling method.

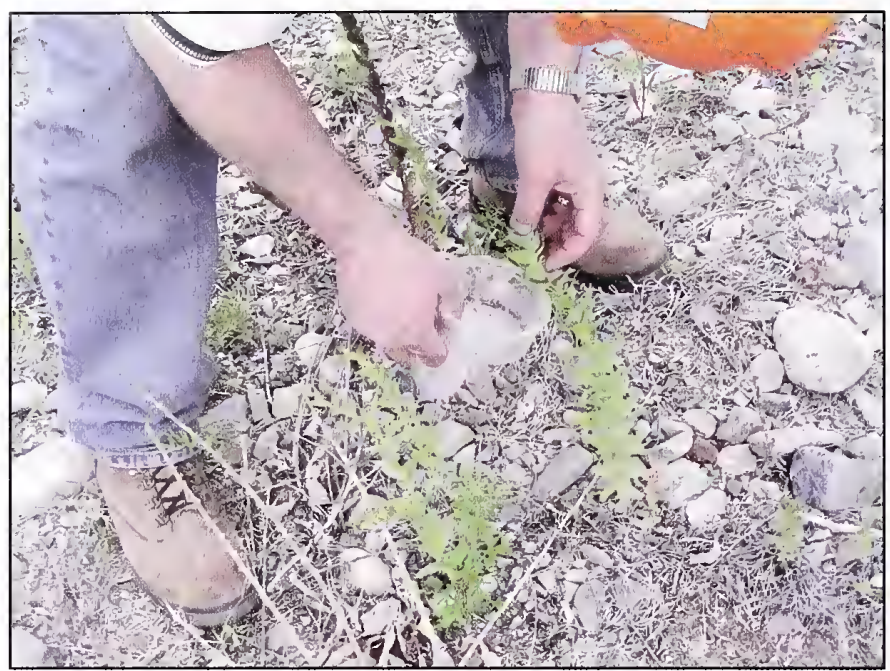

Figure 53. Collecting toadflax biocontrol agents into a plastic cup.

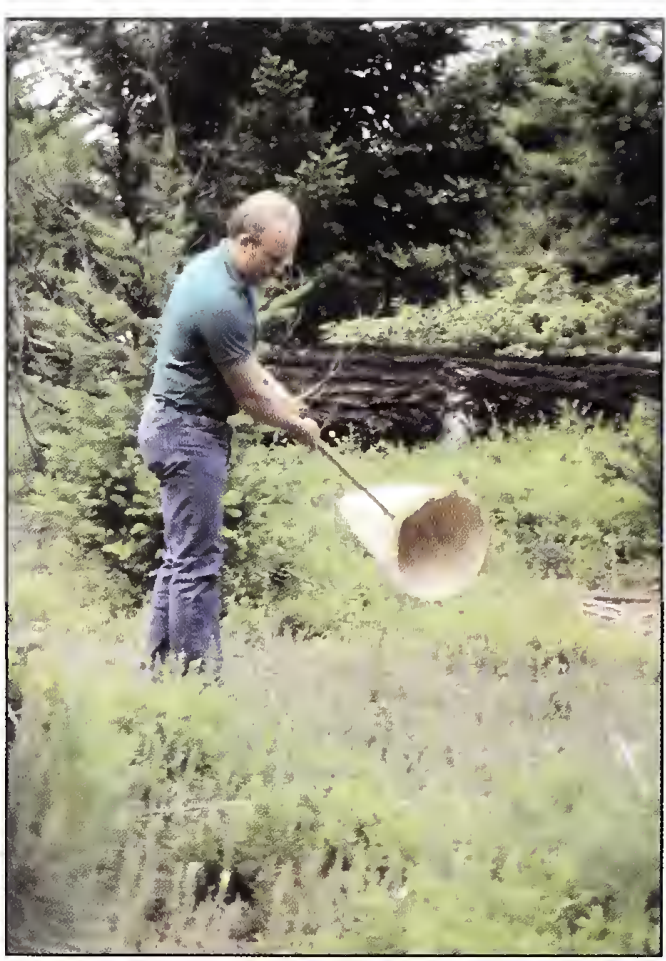

Figure 55. Sweeping to collect Rhinusa antirrhini. 


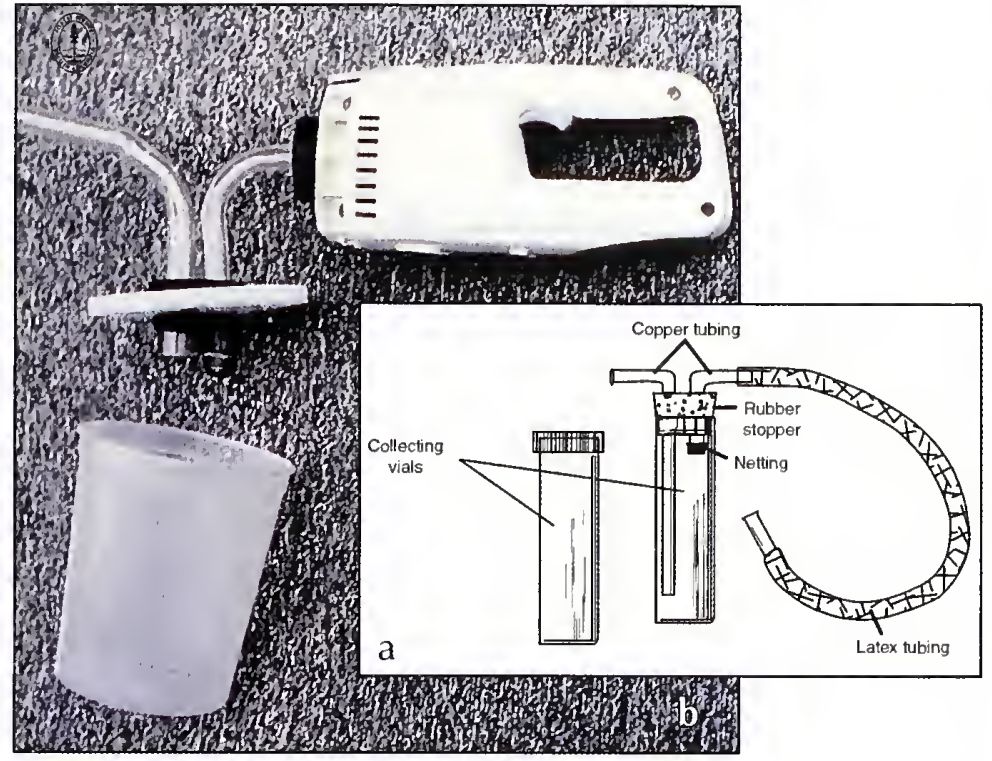

Figure 56. Manual (a) and hand held gasoline or battery-powered (b) vacuum aspirators used to collect insects.

\section{Collecting Guidelines}

Collect biocontrol agents from established field insectaries or from approved open field sites. Be sure you are not collecting from a research site or a new insectary. You may need to contact your state biocontrol expert, county weed coordinator/supervisor, local CWMA, or university researcher to identify the best collection sites and times. Some of the biocontrol agents - such as the flower-feeding beetle, the seed-feeding weevils, and the defoliating moth-are so widespread and abundant that they may already be present at your release site. Therefore, before you collect, inspect the planned release site to be sure the insects you are planning to collect are not already present.

As a general rule of thumb, biocontrol agent populations are large enough to permit redistribution collections if the number of insects recommended for an initial release can be harvested in a fairly short period of time (less than an hour). For example, if 200 adult weevils are recommended for a stem-mining weevil release, you should be able to easily collect several hundred adult weevils in about 30 minutes (or less) from a collectable population. If it takes a long time (several hours) to collect 200 weevils, then the population is not yet large enough to support redistribution collections. Once a population is deemed collectable, agents may be collected. There is generally no danger of over-collecting at an established site, provided 1) collections stop when it becomes difficult to find insects, as above; and 2) collections are made once or, at most, only a few times during a season.

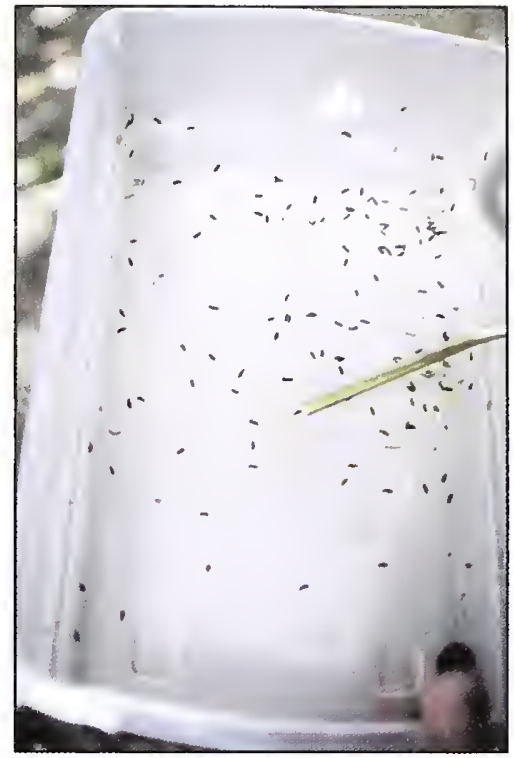

Figure 57. Mecinus janthinus collected into a plastic tub.

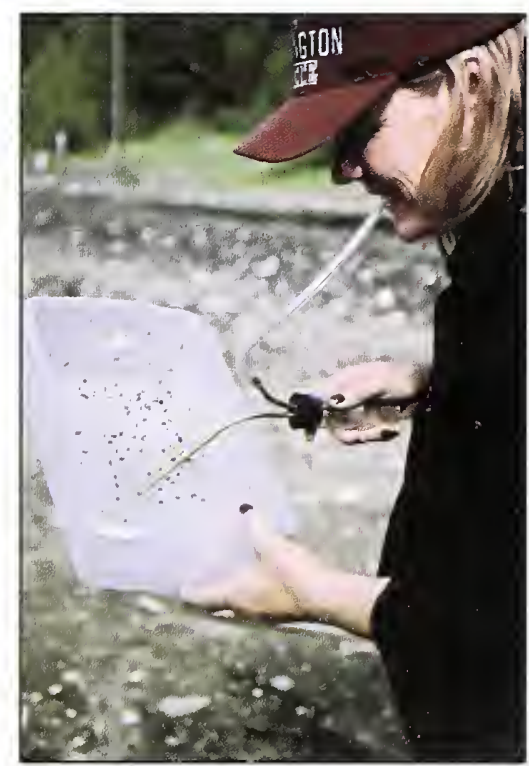

Figure 58. Aspirating Mecinus janthinus from a plastic tub. 
The optimal time for collecting will vary from region to region and year to year, depending mostly on when the adults emerge from overwintering sites. Approximate recommended collection times are provided in Table 6 on page 64 . Wait for a day with good weather. Do not collect in the rain: insects will likely be in protected niches or on the ground and will not be collectable.

All of the toadflax beetles are most efficiently collected as adults. Collect on warm, sunny, relatively calm days when the beetles are most active on the plants. Collect at the time of peak emergence of the beetles, as this will be when they are most abundant and will be mating. Collecting mating pairs of insects will increase the probability that eggs will be laid at the new site. The root-boring moths also are best collected as adults. The defoliating moth is best collected as larvae (caterpillars). Specific collecting guidelines for each of the toadflax biocontrol agents are outlined below.

Flower-feeding beetles (Brachypterolus pulicarius). Collect adult beetles. Adults are easily collected by aspirating individual beetles from inside the flowers and from stem tips. Adults can be collected with the tray sampling method if their populations are large. Sweeping the tops of plants is also a suitable, but slower, method of collecting adults. Depending on location, the best time to collect adult beetles is late May to mid-June, when they have emerged from overwintering sites and are actively feeding, aggregating near the tops of the plants, and mating. The best time of the day to collect adults is mid- to late morning, when they are active but still moving slowly. Adult beetles are very sensitive to heat: hot afternoons cause them to seek shaded niches. Immediately transfer adults from the aspirator or sweep net into a paperboard container in a prepared cooler.

Seed-feeding weevils (Rhinusa antirrbini and $R$. neta). Collect adult beetles. Collect adults when they are actively feeding and mating on the top portions of plants. Adults are easily collected using a net by gently sweeping the tops of the plants. Gently tapping the uppermost portions of the plants over a plastic tub is also effective, and does not damage the plants as much as sweep netting. Aspirating individual adults or mating pairs from plants is possible, but slow and laborious. Collect the seed-feeding weevils during the heat of the day. The optimal period to collect is between the appearance of flower buds and the onset of full flowering. Mating pairs aggregate at the top of plants, and are easily seen. Depending on location, the collecting period is generally from late May (when flowers begin to form but before they open) to late August. More beetles are collected from yellow toadflax than from Dalmatian toadflax.

Stem-mining weevil (Mecinus janthinus). Collect adult beetles. Collect adults when they are actively feeding and mating on the top portions of plants. Adults are collected by tapping plants over tubs to dislodge the adults (Fig. 52). During peak densities, several thousand adults can be collected in 2-3 hours. Depending on location, the collecting period is generally from early May to early July. Based on data from British Columbia releases, visual-timed stem-mining weevil counts of greater than 20 per minute indicate that the population is collectible for redistribution (in 
British Columbia, optimal release sites can be collectable in three to four years after establishment). Long-term observations on release sites in Montana have not yet shown this degree of buildup of local populations of $M$. janthinus five years postrelease.

Root-galling weevil (Rhinusa linariae). Only a few known populations are believed to occur in the United States, so this weevil is not available to collect or for release at this time. Adult beetles are generally collected from mid-May to late July, when they are actively feeding and mating on the top portions of plants, but before females move to the bases of the plants to oviposit. Tapping weevils into collection trays or tubs is the recommended collection method. It may be possible to collect beetles with a sweep net, but flowers may be damaged by sweeping.

Defoliating moth (Calophasia lunula). When collecting the defoliating moth, it is best to collect the larvae because adult moths are fragile and difficult to find and collect. Gently pick larvae from the plants by hand or with the aid of forceps, or carefully dislodge them from foliage into shallow plastic tubs. Larger caterpillars may regurgitate a green liquid when handled; this is a normal defensive response and does not indicate injury. Larvae will frequently drop from the plant when approached or touched. Sweeping is not advised because it will injure the larvae. Young larvae will be found on young foliage or flowers; older larvae are found on larger leaves or stems. The largest number of larvae will be found in open, sparse, scattered stands of Dalmatian toadflax, such as those that occur in waste areas, and along fencerows and transportation or utility line rights-of-way. It is important not to place too many larvae (less than 50) in a container, as overcrowding may result in cannibalism. Caterpillars can be collected from mid-June to October. Because of concerns about the host specificity of this insect and its tendency to disperse widely from its point of release, we do not recommend collecting the defoliating moth for redistribution.

Root-boring moths (Eteobalea intermediella and E. serratella). These insects are not available to collect or release at this time. Because we have no field experience with these insects, these guidelines for collecting, handling and releasing are tentative. Generally, the adult moths are the stage to be collected. Collecting larvae or pupae is not recommended because larvae and pupae can be harmed when roots are cut open to expose them. Collect adults at dusk or dawn with a sweep net or a lightweight butterfly (aerial) net. The moths are small and fragile, so care must be taken to avoid injuring them. Sweep once or twice, then gently pick individual moths from the sweep net by hand and place them into a paperboard container that is filled with crumpled tissue. The crumpled tissue will provide a hiding and resting spot for each moth, and significantly increase their chance for survival until they can be released. Do not put foliage in the container with the adults - they do not eat it. Do not put more than 25 moths into each container. Moths should be immediately transported to the new site and released. Depending on the location of the site, the collecting period for these short-lived adults is generally from May to June (with a second collection period for E. intermediella in July). Because these two species are active at twilight, the best time to collect them is one to two hours after sunset or one hour before sunrise. 
Table 6. Methods and timetable for collecting toadflax biocontrol agents. Timelines are approximate and can vary depending on location (elevation, latitude) and seasonal temperatures.

\begin{tabular}{|c|c|c|c|}
\hline Agent & What to collect & Optimal time to collect & Collection method(s) \\
\hline Brachypterolus pulicarius & Adults & $\begin{array}{l}\text { Late May to mid-June, } \\
\text { when plants are in early } \\
\text { flowering stage }\end{array}$ & $\begin{array}{l}\text { Aspirate or hand-pick } \\
\text { adults from inside flowers, } \\
\text { or collect from shoot tips } \\
\text { using a sweep net or tub }\end{array}$ \\
\hline $\begin{array}{l}\text { Rhinusa antirrhini and } \\
\text { R. neta* }\end{array}$ & Adults & $\begin{array}{l}\text { Late May to mid-June, } \\
\text { when plants are in early } \\
\text { flowering stage }\end{array}$ & Tray sample, sweep net \\
\hline Rhinusa linariae* & Adults & Early May to late July & Tray sample, sweep net \\
\hline Mecinus janthinus & Adults & Early May to early July & Tray sample, sweep net \\
\hline Calophasia lunula & Larvae (caterpillars) & Mid-June to October & $\begin{array}{l}\text { Hand-pick } 2 \text { nd to } 5 \text { th } \\
\text { instar larvae from plants }\end{array}$ \\
\hline Eteobalea serratella & Adults & Mid-May to late June & \multirow{2}{*}{$\begin{array}{l}\text { Gently sweep plants two } \\
\text { hours after sunset or one } \\
\text { hour before dawn }\end{array}$} \\
\hline Eteobalea intermediella & Adults & $\begin{array}{l}\text { Mid- to late May and } \\
\text { again mid- to late July } \\
\text { (2nd generation) }\end{array}$ & \\
\hline
\end{tabular}

* formerly Gymnetron

\subsection{Purchasing toadflax biocontrol agents}

When purchasing biocontrol agents from a commercial supplier or when obtaining insects from a cooperator, it is important to ensure that the insects are healthy and received in good condition. Make sure you know the geographic origin and from what species of toadflax your insects were collected. It is also important to obtain the biocontrol agents at the correct time of year. Be sure also to have the proper, legally required permits for interstate transportation of insects. For more information, to find a commercial supplier, or to obtain a permit, contact your CWMA, your county weed control superintendent, or your state weed biocontrol expert. You can obtain permit applications from the USDA-APHIS-PPQ website (see $h t t p: / /$ www.aphis.usda.gov/ppq/permits/biological/weedbio.html). 


\section{Handling and Releasing Toadflax Biocontrol Agents}

How the insects are handled and transported after they are collected will affect whether they survive and establish at the new site. This section includes guidelines for handling, shipping, and releasing biocontrol agents.

\subsection{Handling toadflax biocontrol agents}

Containers. Refer to Section 4.1 for a description of suitable containers. It is important to use secure, breathable containers that provide air flow to the insects yet prevent condensation and escape. Tightly secure lids on the containers with masking tape, and label containers with the name of the biocontrol agent, the quantity of insects, the collection site name and location, and the date.

Transportation. To minimize stress and harm to the agents, transport and release them as soon as possible-preferably within 24 hours - and minimize the distance they must travel by selecting sources as close to the release site as possible. Ensure that insects have plenty of fresh food at all times. It is not necessary to provide the insects with water, as they will receive all the moisture they need from their food, and additional moisture in the container is excessive and may lead to drowning. Keep containers cool and dry during transportation. Put the containers in a cooler with ice packs secured to the bottom or sides of the cooler for transport to the field. Wrap the ice packs with newspaper to prevent direct cold contact and reduce the buildup of condensation in the containers. Adults, especially beetles, can survive a few days in a refrigerator if necessary, but keep storage time to a minimum, and make sure that temperatures do not fall below freezing. Do not overcrowd agents in the containers. For the defoliating moth, put no more than 50 caterpillars in a container at a time to prevent cannibalism.

\subsection{Shipping toadflax biocontrol agents}

When shipping biocontrol agents, plan the route and timing of your shipment to prevent undue delays and stress on the insects. Collect the insects early in the week (Monday or Tuesday) and ship right away by an overnight courier (for example, DHL, FedEx, UPS, or USPS) to be sure they arrive before the weekend. Instruct your cooperator(s) to release the insects immediately upon receipt. Inform your courier that you are shipping live insects, and be sure your courier does not: 1) irradiate packages, or 2) have special clearance procedures for live insects that would delay the shipment. If a courier cannot insure prompt and safe delivery of your agents, choose another one.

Observe the following general guidelines:

- Know the regulations. It is important to know the regulations pertaining to shipping biocontrol agents across county or state borders. USDA permits are required for interstate and international shipment of biological control agents. To learn the current regulations, and to obtain the permit application (PPQ Form 526), refer to the USDA-APHIS-PPQ website (bttp://www.aphis.usda.gov/ppq). 
- Prepare the insects for shipment. Pack the containers in an insulated shipping box with a frozen ice pack well-secured to the inside (Fig. 59). Seal each frozen ice pack in a plastic freezer bag to prevent condensation inside the box as the ice pack melts.

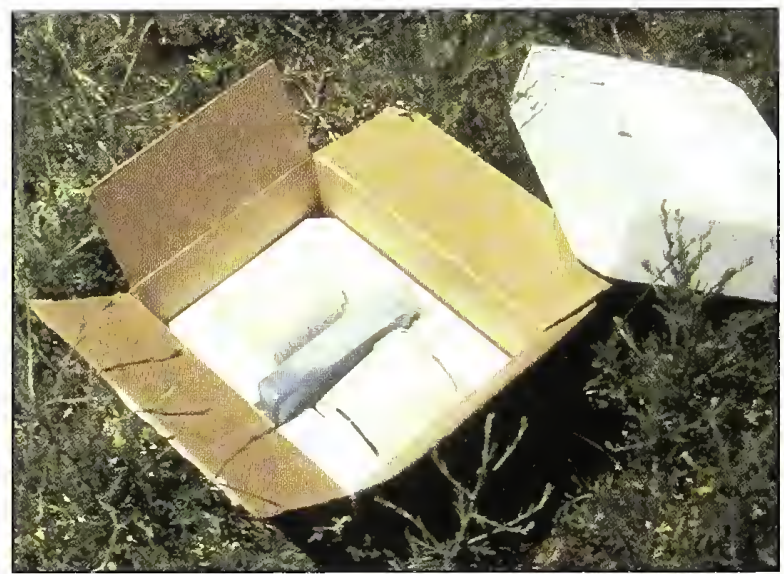

Figure 59. Shipping box used to transport toadflax biocontrol agents.

\section{Common Transportation Mistakes}

- Excess cold. Wrap ice packs in newspaper or other insulating material (e.g., packing 'peanuts' or shredded paper) to ensure there is no direct contact with collection containers.

- Excess heat. Do not expose packaged or containerized biocontrol agents to direct heat or sunlight, or leave them in an non-air-conditioned vehicle for an extended period of time on a sunny day.

- Excess moisture. Do not put water into the containers.

- Lack of air. Use only breathable containers.

- Escape. Make sure container lids are well-secured with masking tape.

- Storage length. Do not store insects more than three days. Supply insects with plenty of food (fresh, contaminant-free toadflax foliage). 


\subsection{Releasing toadflax biocontrol agents}

Many factors can determine whether insects establish and flourish at a release site. Few of these are under our control (weather, wildfire, etc.), but follow these general steps for releasing biocontrol agents to give the insects their best possible start.

Timing the release. Release agents at the optimal toadflax growth stage (see Table 7 on page 69). For example, when releasing the seed-feeding weevils or the flowerfeeding beetle, toadflax should be at or near the flowering stage. If most plants are beyond the flowering stage, it is too late to release at that site. Locate a different toadflax infestation, perhaps at a higher elevation, that is at the correct stage.

Number of biocontrol agents to release per site. The number of insects to release per site depends on the insect species, the size of the infestation, and your goals. Generally for beetles, a minimum release of 200 insects is recommended to establish a population (see Table 7). You may want to release 500 or more beetles if your goals is to establish an insectary site for future collecting.

Release of biocontrol agents. Release insects as soon as possible after you receive them; do not wait for good weather, but avoid heavy downpours. Release in the early morning hours between 6 and 10 a.m. or in the cooler evening hours between 6 and 10 p.m.; biocontrol agents are less likely to immediately scatter if released at cooler times of the day. The exception is the twilight-active root-boring moths, which should be released at dusk or dawn. Take the insects to the chosen release site, open the shipment containers, let the container with insects sit on the ground for a few minutes to acclimate to any change in temperature, and then gently shake all the insects and packing material on the ground at the bases of vigorously growing plants (Fig. 60). Release all the insects at once at a single location; do not scatter them or release them at different points throughout the site. When the insects are released at one location, they can more easily find one another to mate. The insects will naturally disperse. Releasing at one location also makes it easier to relocate the release in the future, and to monitor the insects' dispersal over time.

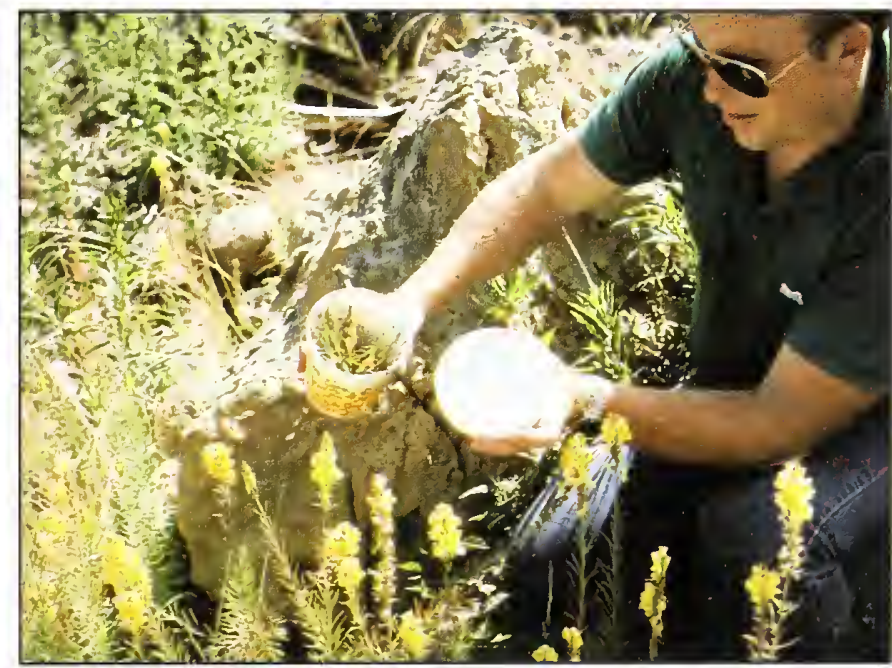

Figure 60. Releasing Rhinusa antirrhini on yellow toadflax. 
Frequency of release. Often, a single release will be sufficient to establish an insect population, especially if it is made with a large number (500 or more) of insects. More than one release may be necessary if previous releases have failed. Do not get discouraged: insects can be difficult to detect in the field, and bear in mind that it could take two or more years to determine if the released agent has successfully established. However, avoid making annual releases over a long period of time (more than four or five consecutive years) at sites where establishment cannot be confirmed.

Placing a permanent location marker. Always place a permanent site marker at the point where you made the insect release. This marker will assist in relocating the site for monitoring and/or collection activities.

Take photos. A series of photographs to record the release location and subsequent changes in vegetation years afterward provides documentation of biological control activities and efficacy (see Section 6).

Complete a Toadflax Biocontrol Release Form (see an example in Appendix C). Submit the form to your county weed superintendent, CWMA, or university or state biocontrol expert. Always keep a copy for your own records.

\section{Specific Release Guidelines}

Specific release guidelines for each of the toadflax biocontrol agents are listed below. Refer to Table 7 for a quick reference.

Flower-feeding beetles (Brachypterolus pulicarius). Release as many adults as is possible to ensure rapid colonization and establishment. Experience has shown that a minimum of 200 adults in needed to obtain successful establishment. Distribute the beetles on the ground at the base of stems in a dense stand of bolted, early-flowering, partially shaded toadflax. Remember to check your site beforehand to make sure that this widely distributed beetle is not already present.

Seed-feeding and root-galling weevils (Rbinusa spp.). Release as many adults as is possible to ensure rapid colonization and establishment. Experience has shown that a minimum of 200 adults can result in successful establishment. Distribute the beetles on the ground at the base of stems in a dense stand of bolted, early-flowering plants growing in full sunlight.

Stem-mining weevil (Mecinus janthinus). Release as many adults as is possible to ensure rapid colonization and establishment. Experience has shown that a minimum release size of 200 adult weevils results in successful establishment, but larger releases accelerate establishment. Distribute the beetles on the ground at the base of stems in a dense stand of young, bolting plants in full sunlight. 
Defoliating moth (Calophasia lunula). Release the larvae into sparse, discontinuous stands of toadflax for the best chance of establishment. Release as many larvae as possible to improve the chance of colonization and subsequent establishment. An optimum release would consist of at least 100 larvae. Individually place larvae directly onto bolted, flowering plants with succulent foliage. Put no more than two larvae on a plant. It is preferable to release larvae collected from Dalmatian toadflax back onto Dalmatian toadflax and larvae obtained from yellow toadflax onto yellow toadflax for the best chance of establishment. Note that the moth will not establish at cold, high elevation locations.

Root-boring moth (Eteobalea spp.). Adults of both species should be released immediately after they are collected as they are fragile and mortality in the containers can be high. Release them on bolting plants at dusk or dawn. Gently remove the tissue from the container and place it at the base of plants in a dense patch of toadflax. Many of the moths will be hidden in the tissue, but they will eventually come out. A minimum of 50 adults is probably adequate for a release.

Table 7. Methods and timetable for releasing toadflax biocontrol agents

\begin{tabular}{|c|c|c|c|c|c|}
\hline Agent & $\begin{array}{l}\text { Life stage } \\
\text { to release }\end{array}$ & $\begin{array}{l}\text { Optimal time to } \\
\text { release }\end{array}$ & $\begin{array}{l}\text { Minimum \# } \\
\text { to release }\end{array}$ & $\begin{array}{l}\text { Optimal plant stage } \\
\text { for release }\end{array}$ & $\begin{array}{l}\text { Release site } \\
\text { criteria }\end{array}$ \\
\hline $\begin{array}{l}\text { Flower-feeding beetle } \\
\text { Brachypterolus pulicarius }\end{array}$ & Adult & $\begin{array}{l}\text { Late May to } \\
\text { mid-June }\end{array}$ & 200 & $\begin{array}{l}\text { Bolted, or early- } \\
\text { flowering plants }\end{array}$ & $\begin{array}{l}\text { Dense infestation, } \\
\text { sunny south- } \\
\text { facing slope }\end{array}$ \\
\hline $\begin{array}{l}\text { Seed-feeding weevils } \\
\text { Rhinusa antirrhini } \\
\text { and } R . \text { neta* }\end{array}$ & Adult & $\begin{array}{l}\text { Late May to late } \\
\text { June }\end{array}$ & 200 & $\begin{array}{l}\text { Bolted, late bud to } \\
\text { early-flowering } \\
\text { stage }\end{array}$ & $\begin{array}{l}\text { Dense infestation, } \\
\text { sunny south- } \\
\text { facing slope }\end{array}$ \\
\hline $\begin{array}{l}\text { Root-galling weevil } \\
\text { Rhinusa linariae* }\end{array}$ & Adult & $\begin{array}{l}\text { Mid-May to late } \\
\text { July }\end{array}$ & $\begin{array}{l}\text { Unknown, } \\
\text { probably } 200\end{array}$ & Early-flowering & Unknown \\
\hline $\begin{array}{l}\text { Stem-mining weevil } \\
\text { Mecinus janthinus }\end{array}$ & Adult & $\begin{array}{l}\text { Early May to } \\
\text { early July }\end{array}$ & 200 & $\begin{array}{l}\text { Bolting (stems } 10- \\
15 \text { in }(24 \text { to } 30 \mathrm{~cm}) \\
\text { high), nonflowering } \\
\text { plants }\end{array}$ & $\begin{array}{l}\text { Dense infestation, } \\
\text { sunny south- } \\
\text { facing slope }\end{array}$ \\
\hline $\begin{array}{l}\text { Defoliating moth } \\
\text { Calophasia lunula }\end{array}$ & $\begin{array}{c}\text { Larva } \\
\text { (caterpillar) }\end{array}$ & $\begin{array}{l}\text { Mid-June to } \\
\text { October }\end{array}$ & 100 & $\begin{array}{l}\text { Bolted, flowering or } \\
\text { nonflowering plants }\end{array}$ & $\begin{array}{l}\text { Dry, open site } \\
\text { with sparse cover } \\
\text { of toadflax }\end{array}$ \\
\hline $\begin{array}{l}\text { Toadflax root-boring moth } \\
\text { Eteobalea intermediella }\end{array}$ & Adult & $\begin{array}{l}\text { Early June and } \\
\text { late July ( } 2 \text { nd } \\
\text { generation) }\end{array}$ & $\begin{array}{l}\text { Unknown, } \\
\text { probably } 50\end{array}$ & $\begin{array}{l}\text { Bolted, flowering or } \\
\text { non-flowering } \\
\text { plants }\end{array}$ & Unknown \\
\hline $\begin{array}{l}\text { Yellow toadflax root-boring } \\
\text { moth } \\
\text { Eteobalea serratella }\end{array}$ & Adult & $\begin{array}{l}\text { Early to mid- } \\
\text { June }\end{array}$ & $\begin{array}{l}\text { Unknown, } \\
\text { probably } 50\end{array}$ & $\begin{array}{l}\text { Bolted, flowering or } \\
\text { non-flowering } \\
\text { plants }\end{array}$ & Unknown \\
\hline
\end{tabular}

\footnotetext{
* formerly Gymnetron
} 


\section{Summary: Handling and Releasing Toadflax Biocontrol Agents}

- Be sure you have valid interstate transport permits, if necessary.

- Use sturdy, breathable containers filled with plant material according to instructions.

- Sort insects before packaging them to ensure that predators (e.g., ants and spiders) or weed seeds are not trapped inside the containers.

- Securely tape lids on shipping containers.

- Avoid physical damage to the biocontrol agents by taping down wrapped ice packs.

- Keep insects cool and dry during transportation.

- If release or shipping is not immediate, store the insects in refrigerators no colder than 40 to $50^{\circ} \mathrm{F}$ ( 4 to $10^{\circ} \mathrm{C}$ ) for no longer than three days, or keep them in an ice chest until they are ready to be shipped or transported. Prolonged storage of collection containers in a refrigerator increases the chance of agents dying by desiccation. The risk of desiccation during storage can be reduced if agents are regularly given fresh toadflax foliage. Releasing the agents as soon as possible after they arrive is always preferable to prolonged storage.

- Release during the cool times of the day; do not wait for good weather.

- Take photos; fill out the release form (Appendix C). 


\section{Monitoring}

\section{Introduction}

The purpose of monitoring is to evaluate your biological control program and to determine if you are meeting your biological control program goals. In biological control of weeds, monitoring is a process that uses a variety of insect and vegetation measuring techniques to enable land managers to answer questions about whether the biocontrol agents' populations are growing at the site and whether they are having an impact on the target weed. Monitoring, as defined by the Bureau of Land Management, is the "systematic collection and analysis of repeated observations or measurements to evaluate changes in condition or progress toward meeting a management objective." Evaluating the success of your toadflax biological control program involves systematic observations or measurements taken over time. This section includes recommendations and guidelines on how to plan and conduct a toadflax biocontrol monitoring program.

There are three main steps in planning a monitoring program:

Step 1: Develop a Monitoring Design:

- Prepare a list of monitoring objectives based upon your stated short- and long-term biological control of toadflax goals.

Step 2: Develop a Monitoring Plan:

- Decide what you will monitor (agent population, target weed density, etc.).

- Decide how often you will monitor (annually, every other year).

Step 3: Identifying Monitoring Activities:

- Outline exact methods and timeline.

- Decide where you will monitor.

\subsection{Determining your monitoring objectives}

Appropriate monitoring objectives can only be devised if you have clearly-defined short- and long-term toadflax biocontrol program goals. Well-defined monitoring objectives will enable you to assess the success of your biocontrol program. Monitoring objectives should be the basis of your monitoring design.

Your monitoring methods can differ among sites, depending on your biocontrol objectives and what type of information you want to gather at each site. If your biological control objective is to determine whether the biocontrol agents have established at a site, your monitoring activities will require much less effort and expense than if your biological control objective also includes determining whether the toadflax population is declining at the site and what vegetation changes have occurred. 
When beginning a toadflax biological control program, it is important to keep your monitoring design and methods as simple and straightforward as possible. Many new biological control practitioners make the mistake of creating data- and labor-intensive monitoring systems that become burdensome and are quickly abandoned. Biological control programs often take a number of years to begin to show results, so monitoring systems should recognize and adjust for this "lag time." The key to successful biological control monitoring is simplicity and perseverance.

\subsection{Planning your monitoring activities}

Consider the Questions to Ask (in the box below) and the Monitoring Plan Questionnaire (Appendix D) to help identify meaningful objectives of your monitoring program.

\section{Some Monitoring Questions to Ask}

- Have the biocontrol agents successfully established at the site?

- Are the biocontrol agent populations increasing or declining?

- How far have biocontrol agents spread from the initial release sites?

- Are the biocontrol agents found in sufficient number to be collected and redistributed?

- Are the biocontrol agents causing visible damage to the target weed?

- Are the biocontrol agents feeding on nontarget plants (plants other than toadflax)?

- Is the toadflax population declining at the site?

- Are changes occurring within the plant community (composition and structure)?

Answers to these questions will allow land managers to do the following:

- Gauge the success of the toadflax biological control program.

- Determine whether supplemental biocontrol agent releases or other weed management activities are necessary.

- Confirm that biocontrol agents are having an impact on toadflax.

- Document changes in the plant community.

Each monitoring design should be tailored to fit the needs and resources available to the land manager while helping to address short- and long-term weed management goals. After a monitoring design has been developed, land managers need to devise a monitoring plan. A monitoring plan deals with logistics, basically detailing what will be monitored and how often. Once a plan has been finalized, monitoring methods should be identified and should proceed as planned for as long as necessary to meet the needs of the monitoring design. As initial biological control program goals are reached, new goals may be identified, and monitoring designs and activities can be adjusted to address these new goals. 
No single monitoring design or plan will meet every manager's needs, but there are standardized monitoring methods for measuring insect presence and abundance, weed density, and vegetation community composition and structure that can be incorporated into many different monitoring plans.

Monitoring methods vary in intensity and precision. Methods adopted for a particular monitoring plan should reflect the needs for the quantity and quality of data collected as outlined in the monitoring design. Intensive monitoring beyond what is required to determine whether your biological control goals are being met is never desirable: it wastes time and resources and is not likely to be consistently carried out or completed.

Monitoring in a toadflax biological control program will generally involve measuring three distinct factors: biocontrol agent population presence and abundance, biocontrol agent impact on toadflax, and plant community structure and composition. Listed below are some considerations distinct to each factor.

Monitoring biocontrol agent populations:

- Because agents are generally small, often well-hidden, and mobile, it may take several years for them to become abundant enough to be easily detected by land managers. An inability to find agents one, two, or even three years after release does not necessarily mean that the agents did not establish.

- Often, the first indication that an agent has established may be evidence of plant damage and not the biocontrol agents themselves. Signs of an agent's presence at the site may be oviposition scars (where adults laid their eggs), swollen seed capsules, feeding holes on leaves, leafless stems, or wilted stems that, when dissected, are found to contain frass (a combination of chewed plant material and insect excrement), larvae, or pupae.

- Knowing when and where the biocontrol agent feeds or can be found during your planned monitoring time will increase monitoring success. Understanding what type of damage you can expect to see from the agents in your biological control program will help you develop an appropriate monitoring methodology to characterize their impact on the target weed. Remember that widely distributed agents such as the seed-feeding weevils, the flower-feeding beetle, and the defoliating moth may already be present at your biocontrol site, even if you did not put them there.

Monitor toadflax and other plants in the community:

- The goal of many biological control programs is to reduce the abundance and competitiveness of toadflax, enabling desirable vegetation to increase at the release site. Some level of plant community monitoring will be necessary to determine if this goal is being met. The type and intensity of plant community monitoring is dictated by the type of information needed. 
- There are many vegetation monitoring protocols currently in use: some are visually-oriented (qualitative monitoring systems), while others are measurementoriented (quantitative monitoring systems).

- In order to correlate a decline in toadflax abundance to the location application of biological control, it is important to measure vegetation structure and composition before release of the biocontrol agent(s) and to periodically remeasure the vegetation as agents become established and impact the toadflax on an individual and population basis.

\section{General Planning Guidelines}

The following guidelines are provided to help you as you develop your biological control monitoring plan.

Decide where to begin monitoring. The best place to begin monitoring is where the insects were first released; hopefully, the release point has been permanently marked (see section 5.3). This is typically where the highest density of biocontrol agents is likely to occur, and where changes to the toadflax plants are often first detected. If you do not find agents, continue to explore the area around the release site. Sometimes agents do not like the exact spot where you released them and will move to a more suitable location within the toadflax infestation. Some biocontrol agents prefer to disperse along a specific gradient in the environment; for example, the stem-mining weevil will generally disperse uphill more frequently than downhill from a release point. Remember that it may take three or more years for agent populations to reach a detectable level.

Decide when to begin monitoring. Monitoring toadflax should begin a year or two before you release biocontrol agents. This gives you pre-release, baseline data on the amount of toadflax at the site as well as an indication of the amount of natural toadflax variation year-to-year. This pre-release information will enable you to draw stronger conclusions about the role of biological control in any plant community changes you observe.

Schedule monitoring activities. Schedule monitoring activities to occur at approximately the same time each year to enable valid year-to-year comparisons. Know what you want to sample when developing your monitoring schedule. If you want to take photographs of infestations in flower, be sure that you schedule monitoring activities to coincide with peak flowering. If you want to sample agent populations during the period of peak adult activity, be sure that you know when that occurs in your area. Keep in mind that, when late winter and spring weather patterns vary dramatically from year to year, biological phenomena such as peak flowering or adult emergence may atso vary by several weeks. Be sure your schedule is flexible to account for year to year changes in timing.

Level of precision. An important consideration when planning your monitoring activities is to determine how precisely you need to measure your selected criteria. If your goal with biological control is to achieve a 30 percent reduction of toadflax cover, your monitoring activities will likely be more exhaustive than if your goal is to 
observe a noticeable reduction in toadflax over five years. In the first example, actual vegetation measurements must be made to allow you to quantify a percent reduction; in the second example, a photograph of the pre-release infestation and one taken five years after release at the same time of year may be adequate to determine if your goal of a noticeable reduction was met.

Retain voucher specimens of biocontrol agents. A recommended practice when monitoring biocontrol agent populations is to collect voucher specimens, a sample of five to six live agents that have been collected and pinned or preserved in alcohol, and retained for identification purposes as part of a permanent record of the release. Ideally, you should take voucher specimens from the shipping container at the time of release, and then collect additional specimens a few years post-release to confirm the successful establishment of the agent. Vouchering biocontrol agent specimens at release and post-release appropriately corroborates any decline in the toadflax infestation with a specific biocontrol species.

Choose a monitoring method. Select a monitoring method based on your monitoring plan. You should decide in advance what information you want to gather and the number of sites you intend to monitor. It is important to use the same monitoring methods year after year.

\subsection{Monitoring methods}

The following section outlines a number of monitoring methods that address common questions among practitioners concerning their biological control program. Usually, questions about biocontrol programs change over time. For example, when the biocontrol agents are first released at the site, the initial question generally is: "Did the biocontrol agent establish at the release site?" (Question 1 below), and once establishment has been confirmed: "Is the agent's population growing at the site?" (Question 2 ). Over time, the focus of monitoring questions usually changes to: "Is the abundance of toadflax declining at the site?" (Question 3) and "Is the abundance of other plant species increasing at the site?" (Question 4)-questions that address changes in the vegetation. Although it may take several years after agents are released to detect these types of vegetation changes, it is important to conduct vegetation monitoring early and regularly in order to be able to document a correlation between biocontrol agent population growth and expansion, and plant community change. Another important question for land managers to consider is: "Is the biocontrol agent impacting nontarget plant species?" (Question 5). The following section addresses each of these questions with commonly used monitoring methods tailored to answer each specific question.

Question 1: Did the biocontrol agent establish at the release site?

Question 2: Is the agent's population growing at the site?

Question 3: Is the abundance of toadflax declining at the site?

Question 4: Is the abundance of other plant species increasing at the site?

Question 5: Is the biocontrol agent impacting nontarget plant species? 


\section{QUESTION 1: Did the biocontrol agent establish at the release site?}

\section{COMMONLY USED MONITORING METHODS}

For beetles. In order to determine whether the biocontrol agent established at the site, you need only observe the agent, or evidence of the agent at the site. You can look for either 1) one or more life stages of the agent, or 2) parts of the toadflax plant damaged by the agent. For example, in order to determine if the seed-feeding weevils have established, you can look for either adults on the plant or evidence of adult feeding damage (Fig. 61). You can also look for larvae inside the seed capsules, or you can look for the characteristic swollen seed capsules that are evidence of weevil attack (see Fig. 45). Refer to Table 8 for specific recommendations for each beetle.

For moths. To determine if the defoliating moth is established at the site, look for caterpillars on plants or look for defoliated stems (Fig. 62). Defoliation damage caused by moth larvae can be severe at favorable sites with a high density of caterpillars. Caterpillars eat the youngest, uppermost leaves first, then move down the plant and consume larger, older leaves. During the middle of the summer, both small, pale caterpillars, and large, brightly-colored caterpillars can be found on plants at the same time. The root-boring moths are also monitored in the larval stage, as adults are difficult to see in the field, usually hiding and inactive during the day.

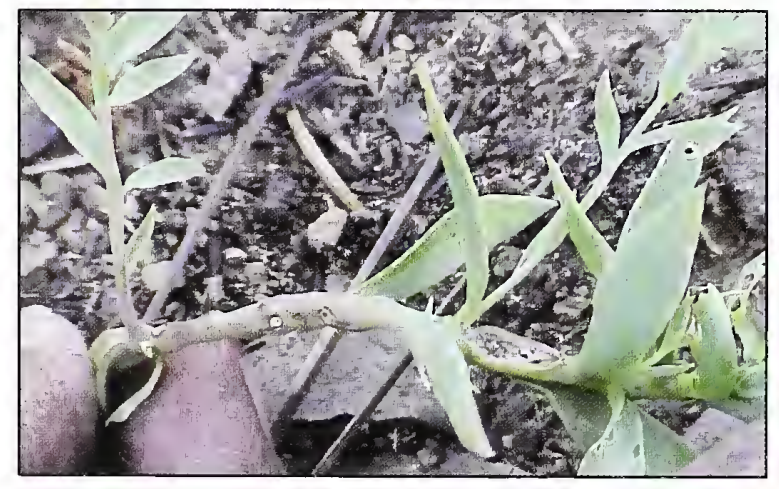

Figure 61. Characteristic foliage damage caused by adult Mecinus janthinus feeding. UGA1416051

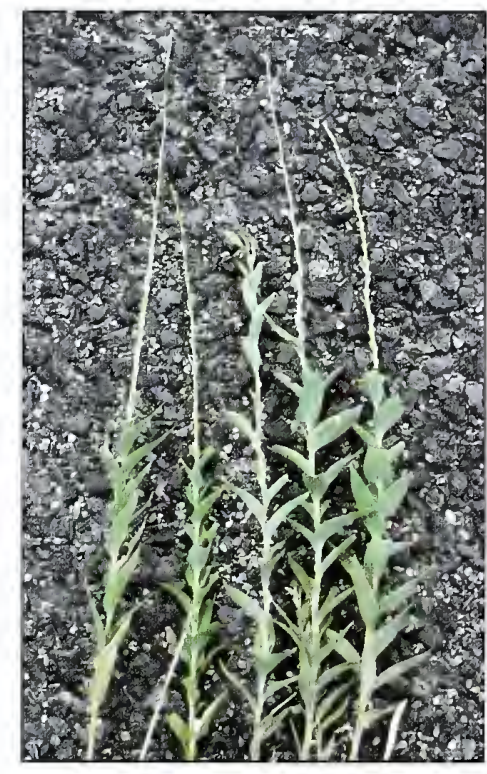

Figure 62. Defoliation of Dalmatian toadflax by Calophasia caterpillars. UGA1416052 
Table 8. Methods and timetable to determine establishment of toadflax biocontrol agents.

\begin{tabular}{|c|c|c|c|}
\hline Agent & Life stage & What to observe & When to observe \\
\hline \multirow[t]{2}{*}{$\begin{array}{l}\text { Flower-feeding beetle } \\
\text { Brachypterolus pulicarius }\end{array}$} & Adult & $\begin{array}{l}\text { Observe adults inside } \\
\text { flowers or their feeding } \\
\text { damage to flowers and } \\
\text { shoot tips }\end{array}$ & $\begin{array}{l}\text { Late May to mid-June at } \\
\text { early-flowering stage }\end{array}$ \\
\hline & Larva & $\begin{array}{l}\text { Observe larvae inside } \\
\text { flowers }\end{array}$ & June to late July \\
\hline \multirow{2}{*}{$\begin{array}{l}\text { Seed-feeding weevils } \\
\text { Rhinusa antirrhini* } \\
\text { and } R . \text { neta* }\end{array}$} & Adult & $\begin{array}{l}\text { Observe adults on plants } \\
\text { or feeding damage }\end{array}$ & $\begin{array}{l}\text { Late May to late August a } \\
\text { bud to flowering stage }\end{array}$ \\
\hline & Larva & $\begin{array}{l}\text { Observe larvae inside } \\
\text { flowers, observe swollen } \\
\text { seed capsules }\end{array}$ & June to September \\
\hline \multirow[t]{2}{*}{$\begin{array}{l}\text { Root-galling weevil } \\
\text { Rhinusa linariae* }\end{array}$} & Adult & $\begin{array}{l}\text { Observe adults on plants } \\
\text { or their feeding damage }\end{array}$ & $\begin{array}{l}\text { May through July at bud } \\
\text { to flowering stage }\end{array}$ \\
\hline & Larva & $\begin{array}{l}\text { Dig roots to examine for } \\
\text { galls }\end{array}$ & $\begin{array}{l}\text { Late summer (August to } \\
\text { October) }\end{array}$ \\
\hline \multirow[t]{3}{*}{$\begin{array}{l}\text { Stem-mining weevil } \\
\text { Mecinus janthinus }\end{array}$} & \multirow{2}{*}{ Adult } & $\begin{array}{l}\text { Observe adults on plants } \\
\text { or characteristic feeding } \\
\text { damage patterns }\end{array}$ & $\begin{array}{l}\text { Mid-May to early July at } \\
\text { bud to flowering stage }\end{array}$ \\
\hline & & $\begin{array}{l}\text { Emergence holes in last } \\
\text { year's stems }\end{array}$ & $\begin{array}{l}\text { Mid-May through } \\
\text { September }\end{array}$ \\
\hline & Larva & $\begin{array}{l}\text { Observe larvae inside } \\
\text { stems }\end{array}$ & June to September \\
\hline $\begin{array}{l}\text { Defoliating moth } \\
\text { Calophasia lunula }\end{array}$ & Larva & $\begin{array}{l}\text { Observe caterpillars on } \\
\text { plants }\end{array}$ & $\begin{array}{l}\text { June to September on } \\
\text { plant foliage }\end{array}$ \\
\hline $\begin{array}{l}\text { Root-boring moth } \\
\text { Eteobalea intermediella/E. } \\
\text { serratella }\end{array}$ & Larva or pupa & $\begin{array}{l}\text { Dig roots to examine for } \\
\text { larval tunnels }\end{array}$ & $\begin{array}{l}\text { Late summer (August and } \\
\text { September) }\end{array}$ \\
\hline
\end{tabular}

* formerly Gymnetron 


\section{QUESTION 2 : Is the agent's population growing at the site?}

\section{COMMONLY USED MONITORING METHODS}

In order to determine whether the agent's population is growing over time, you need to 1) count or estimate the density of biocontrol agents, and 2) repeat the counts or estimates over time (at least three years). Keep in mind that when monitoring biological control agents over time, you should: 1) use a consistent method, and 2) conduct monitoring at roughly the same time each year. Using the same monitoring method from year to year enables you to detect the general trends in the agent's population. Also, using the same monitoring method at different sites allows you to compare an agent's density and rate of population growth in different environments. This also enables researchers and managers to evaluate the success of their toadflax biocontrol programs and may perhaps enable managers and researchers to understand why certain releases fail to establish or to have an impact on toadflax.

The methods described below can also be used to determine if the agent's population has become large enough to permit collecting for redistribution to other sites. For more detailed information, refer to the collecting guidelines discussed earlier in this chapter (section 4.1).

It is important to remember that any monitoring system need only be as intensive as necessary to determine if management objectives are being met. There are various techniques for sampling insects to determine their relative abundance. Three common sampling techniques - timed counting, sweep net sampling, and tray sampling-are described below. A sample Toadflax Biocontrol - Insect Monitoring Form (Appen$\operatorname{dix} \mathrm{E}$ ) is provided for recording insect monitoring information.

Timed counting. This method is used to monitor adult beetles and larvae of the defoliating moth. Beginning at the release point marker, randomly walk at a slow, steady pace within the infestation, staying within $32 \mathrm{yd}(30 \mathrm{~m})$ of the release point. Accuracy is increased if you avoid backtracking over the same area because both beetles and caterpillars are easily brushed off or fall from toadflax. Count all the agents you see on the toadflax plants, concentrating on the top portions of the plants, and record the number of insects observed. Schedule monitoring to coincide with the peak emergence of the adult stage of the biocontrol agent that you are sampling (or caterpillars of the defoliating moth). The amount of time set aside for counting depends on the species of insect you are monitoring. Refer to Table 9 on page 80 for recommended counting time for each insect. Record the number of insects counted for each time period on the data form (Appendix E).

Sweep net sampling. This method is used to monitor adult beetles. Using a sturdy canvas net, gently sweep the upper 4 in $(10 \mathrm{~cm})$ of the plant. Avoid sweeping lower on the plants as you will collect lots of broken plant pieces in your net and not necessarily collect more beetles. Walk in a straight line through the infestation, sweeping five times to make one sample. Open the net after the five sweeps and count any biocontrol insects collected, or empty your sweep net into a white tray, count the insects, and then release them. Repeat this sample 19 more times to make 20 samples, 
total, per site. Record the number of beetles collected for each of the 20 sweep samples on the data form (Appendix E).

Tray sampling. This method is particularly useful when monitoring low to medium population densities of adult biocontrol beetles. Use a white or light-colored, rectangular, plastic tray, pan, or other flat receptacle about $12-18$ in $(30-46 \mathrm{~cm})$ on the longest side. Take 20 samples at each site. For each sample, walk in a straight line through the infestation, gently hold one toadflax stem or a handful of toadflax stems, and shake or tap the upper stems five or six times over the collecting tray. This will dislodge some of the adults present; they can then be easily counted on the tray and released. Record the number of beetles collected for each of the 20 tray samples on the data form (Appendix E).

\section{RECOMMENDED MONITORING METHODS FOR SPECIFIC TOADFLAX BIOCONTROL AGENTS}

The following section describes specific monitoring schemes for each of the toadflax agents.

For seed-feeding, root-galling, and stem-mining weevils. All of the weevils are best monitored at the adult stage. Larvae of the weevils live inside the plant (seed capsules, roots, or stems) and are not visible, or would be harmed or killed if you opened those plant parts to look for them. Adult weevils can be counted or collected by sweep-netting or tray-sampling. See Table 9.

For the flower-feeding beetle. Searching within the toadflax flowers is an effective way to monitor the flower-feeding beetle because this is where the adult beetles feed and mate. The flowers can be opened by pressing gently but firmly on the sides, or by pulling apart the top and bottom 'lips'. Look within five open flowers per plant, then move several paces through the patch of toadflax or until you encounter another toadflax plant. Look inside another five flowers on this plant, and so on. Do not skip unhealthy-looking plants. Examining 100 flowers on 20 plants should take about 10 minutes.

Note:

- The beetles tend to aggregate in the flowers so you may find none in some plants and then several within a single flower.

- After 10 minutes of searching, if you do not find any adult flower-feeding beetles, then the population is either extremely small or the beetles are absent entirely. If you find only around four beetles within the first 100 flowers, there is probably only a small population at the site. If you find 10 or more beetles in the first 100 flowers, the local population can be considered large.

- Sweep-net sampling is effective, but can damage the shoot tips. When sweeping, fewer than 10 beetles collected per sweep indicates a small population, while more than 30 beetles collected per sweep indicates a large population. 
For the defoliating moth. The defoliating moth is monitored in the larval (caterpillar) stage. This is because the adult moths are difficult to see in the field. Look for both small and large caterpillars on the plants. The moth can be monitored from June to September-caterpillars will be large and more visible later in the season. Slowly walk through the infestation and carefully inspect the plants. Visually count for 15 minutes the number of caterpillars observed on stems and leaves of toadflax plants at the site, and record the number of larvae counted.

Note:

- Small caterpillars will often be concealed under the leaves, so it can take a few minutes to inspect a large toadflax plant.

- Larger, older caterpillars tend to stretch out along the stems or on the top side of the leaves and stem branches early in the day to warm from the sun, but are often concealed under leaves during the hottest part of the day in midsummer.

- Usually only a few caterpillars will be found per plant, but if you find one plant with larvae, surrounding plants will usually also yield a few caterpillars.

For the root-boring moths. The two species of root-boring moths are not known to be established in North America at this time. Consequently, monitoring techniques have not yet been developed for these insects. The adults are small, dark moths that are difficult to see in the field, so it is better to dig roots in the late summer to observe larvae or their tunnels in the roots. Digging roots is destructive to the larvae and roots, so it is important to minimize root sampling when the agent is in the earliest stages of establishment and the population is still low.

Table 9. Methods to monitor toadflax biocontrol agents.

\begin{tabular}{|c|c|c|c|}
\hline Agent & Time to observe & Method 1 & Method 2 \\
\hline $\begin{array}{l}\text { Flower-feeding beetle } \\
\text { Brachypterolus pulicarius }\end{array}$ & $\begin{array}{l}\text { Late May to mid-June at } \\
\text { early-flowering stage }\end{array}$ & $\begin{array}{l}\text { Count beetles in flowers } \\
\text { for } 10 \mathrm{~min} .\end{array}$ & $\begin{array}{l}\text { Sweep net sampling or } \\
\text { tray sampling }\end{array}$ \\
\hline $\begin{array}{l}\text { Seed-feeding weevils } \\
\text { Rhinusa antirrhini/R. } \\
\text { neta* }\end{array}$ & $\begin{array}{l}\text { Late May to late August at } \\
\text { bud to flowering stage }\end{array}$ & Sweep net sampling & Tray sampling \\
\hline $\begin{array}{l}\text { Root-galling weevil } \\
\text { Rhinusa linariae* }\end{array}$ & $\begin{array}{l}\text { May through July at bud } \\
\text { to flowering stage }\end{array}$ & Sweep net sampling & $\begin{array}{l}\text { Aspirate directly from } \\
\text { plants, or tray sample }\end{array}$ \\
\hline $\begin{array}{l}\text { Stem-mining weevil } \\
\text { Mecinus janthinus }\end{array}$ & $\begin{array}{l}\text { Late May to early July at } \\
\text { bud to flowering stage }\end{array}$ & $\begin{array}{l}\text { Count weevils on stems } \\
\text { and foliage for } 5 \mathrm{~min} .\end{array}$ & $\begin{array}{l}\text { Tray sampling or sweep } \\
\text { net sampling }\end{array}$ \\
\hline $\begin{array}{l}\text { Defoliating moth } \\
\text { Calophasia lunula }\end{array}$ & June to September & $\begin{array}{l}\text { Count larvae on plants for } \\
15 \mathrm{~min} \text {. }\end{array}$ & \\
\hline $\begin{array}{l}\text { Root-boring moth } \\
\text { Eteobalea intermediella } \\
\text { and E. serratella }\end{array}$ & $\begin{array}{l}\text { Late summer (August and } \\
\text { September) }\end{array}$ & $\begin{array}{l}\text { Dig } 25 \text { roots to examine } \\
\text { for larval tunnels }\end{array}$ & \\
\hline
\end{tabular}

*formerly Gymnetron 


\section{QUESTION 3: Is the abundance of toadflax declining at the site? QUESTION 4: Is the abundance of other plant species increasing at the site?}

\section{COMMONLY USED MONITORING METHODS}

Both these questions can be answered using similar vegetation sampling methods. There are many methods to monitor vegetation. Some agencies (e.g., USFS, BLM) have developed their own vegetation monitoring protocols to ensure vegetation data is collected in a consistent manner for entry into corporate databases and to facilitate data collection for landscape-level land management planning. Much of the data already collected in support of agency land management decision-making can be used to help determine whether biological control goals are being met. For further information about federal agency monitoring protocols and databases (such as FSVEG and TERRA), please refer to http://fsweb.sandy.wo.fs.fed.us/terra. A field guide for invasive plant inventory, monitoring, and mapping using TERRA data standards, protocols, and forms can be found at: http://fsweb.wo.fs.fed.us/rge/invasives/documents/treatment/TreatmentProtocol3.doc.

For land managers without established vegetation monitoring and reporting protocols, the monitoring design, plan, and methods you adopt will depend on your monitoring needs and available resources (personnel and funding) for collecting the data. A valuable online reference, Sampling Vegetation Attributes - Interagency Technical Reference (http://www.blm.gov/nstc/library/pdf/samplveg.pdf), produced by the BLM, provides technical descriptions and methods for every aspect of vegetation monitoring, from planning to field data collection methods.

Two quick vegetation monitoring schemes are used in weed biological control. The 'qualitative' schemes are visual assessments of the status of vegetation at the site.

They do not involve measuring the vegetation, and thus are relatively quick while at the same time provide useful information on the vegetation status at a release site. These schemes are:

1) Visual Estimates of Vegetation: This method uses visual estimates of plant cover to estimate toadflax density (the number of plants in a given area), distribution, and phenology across the entire site. It can also list other plant species occurring at the site. A Toadflax Biocontrol - Qualitative Monitoring Form is provided for recording information gathered from visual assessments of vegetation (see Appendix F).

2) Photo Record of Vegetation: Another way to quickly monitor vegetation at your biocontrol sites is to take a series of photographs. A series of "before-and-after" photographs (Fig. 63) produces a visual record of changes in the vegetation over time, and can document significant changes in weed abundance. Sequential photographs can be meaningful indicators of how quickly (or slowly) weed abundance changed and, when supplemented with data on biocontrol agent establishment and abundance, can support the conclusion that the presence of biocontrol agents contributed to observable changes in the toadflax population. Establish a set of photo points with the permanent marker at the release point in the fore- 
ground, and, if possible, a recognizable, persistent landscape feature, such as a fence, stand of trees, or mountain peak, in the background. Photos should be taken systematically in each cardinal direction (N, S, E, W) using the same type of camera and lens from year to year. Notes describing each photograph in the sequence are useful to ensure that your reference images are correctly identified.

Make sure that your photos capture the full extent of the weed problem. This can be done by taking your photos at the time during the growing season when the weeds show up best against the backdrop of the rest of the vegetation, such as during peak flowering. Follow-up photos should be taken annually, or every other year, as close to the same time that the initial year's photo points were taken, to document changes in target weed abundance, and changes in vegetation community composition.

Several photos or digital images may need to be taken to encompass a large infestation in which biocontrol agents are released. These can be spliced to form composite images of the infestation. Download images or process film as soon as possible after the photos are taken, then archive them, along with your image notes, in an organized, systematic fashion so that you or anyone else will know what the pictures are (site location, cardinal direction, target weed, biocontrol agent(s), management area, etc.) when viewed in the future.

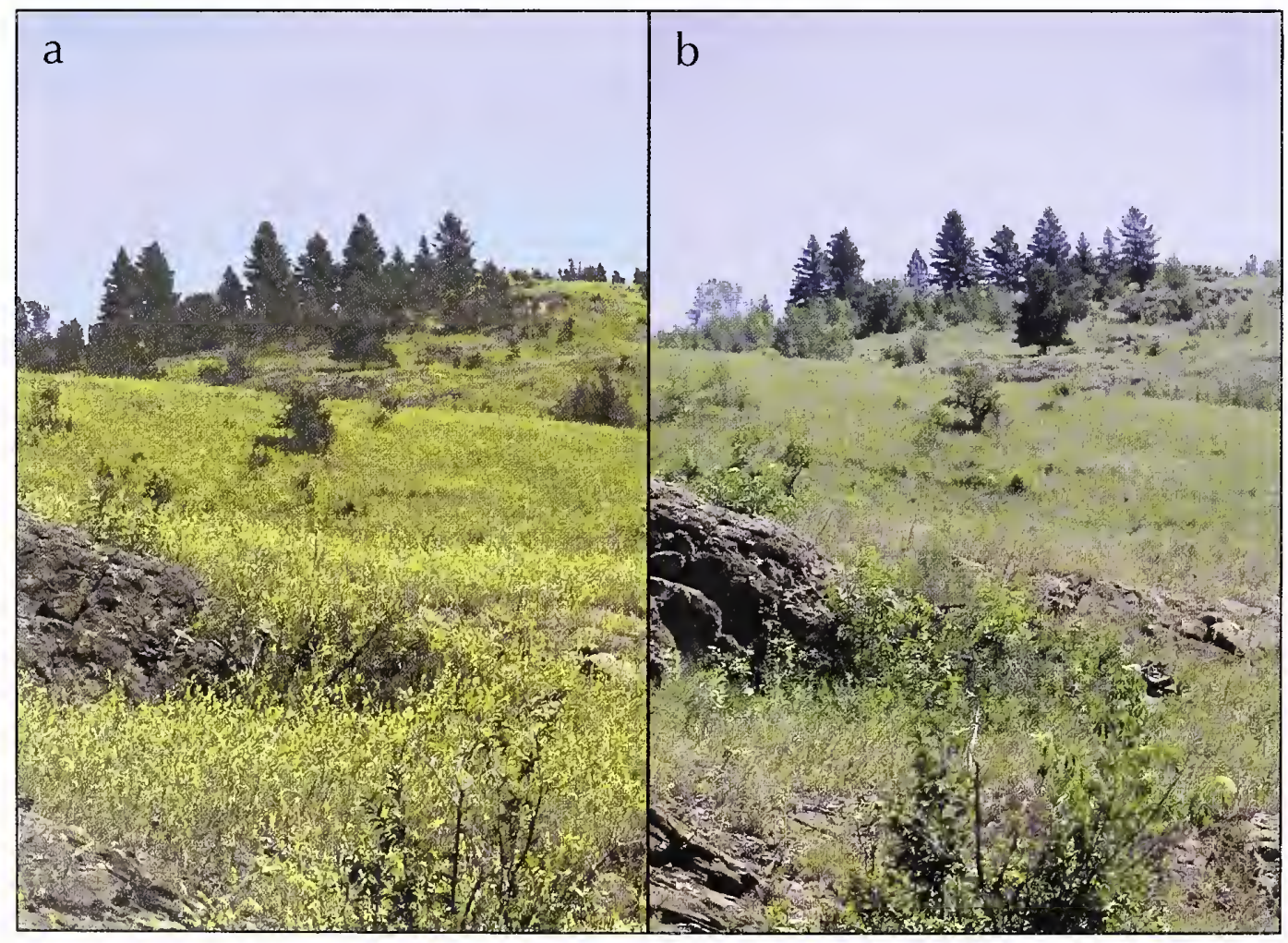

Figure 63. Infestation of Dalmatian toadflax a) before (1996) and b) after (1999) release of Mecinus janthinus. 
When more precision is required in the description of plant community changes, vegetation monitoring schemes need to be more detailed. In many cases, vegetation is measured over time from a permanently marked sample area. A commonly used vegetation monitoring protocol for assessing vegetation is described below. This protocol is relatively easy to use, quick to conduct during the field season, and provides a large amount of very useful information. When used over several years, strong evidence for changes in toadflax populations and other vegetation in the community can be documented.

A key feature of this protocol is that it assesses plants within a small area of uniform size. We recommend a small, rectangular quadrat measuring $1.5 \times 0.7 \mathrm{ft}(0.5 \times 0.2 \mathrm{~m})$ (Fig. 64). It is important to place quadrats randomly in the toadflax infestation. Many methods are available to randomize the quadrat placement. The easiest is to place quadrats along a transect, which is a straight line running through the infestation where the biocontrol agents were released. Once a transect is established, quadrats can then be located at specified intervals (e.g., every 16, 33, or $66 \mathrm{ft}(5,10$, or $20 \mathrm{~m}$ )) along the transect (Fig. 65). Follow these guidelines:

1. Collect materials.

- For each quadrat frame: Rectangular quadrat frames can be constructed of metal (Fig. 64), galvanized steel rods, or PVC pipe and joints. The inside dimensions of the finished frame should measure 19.5 in $(20 \mathrm{~cm})$ wide $\times 39$ in $(50 \mathrm{~cm})$ long, to encompass a total area of $0.1 \mathrm{~m}^{2}$. You can construct the frame yourself, or have a welding or machine shop weld the sides together for you. Mark in 4 in $(10 \mathrm{~cm})$ intervals on each side of the frame using paint or a permanent marker to assist in estimating percent cover.

- Yard (or meter) measuring sticks (to measure plant height)

- $150 \mathrm{ft}$ (or $50 \mathrm{~m}$ ) measuring tape (to make the transect)

- Four plastic or galvanized metal stakes (galvanized metal electric conduit or PVC pipe is inexpensive and readily available from hardware stores)

- Hammer

- Permanent marker

- Compass

- Handheld GPS receiver (if available)

- Camera

- Stopwatch

- Clipboard, pencils, and pen

- Data form (see Appendix G and Instructions)

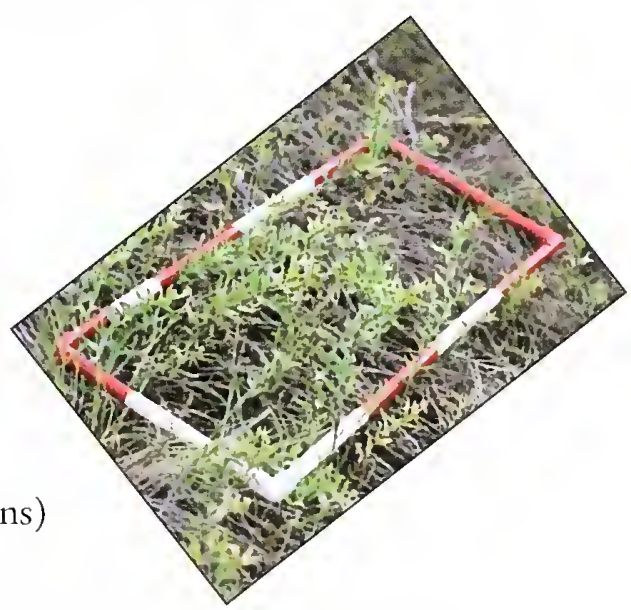

Figure 64. Metal quadrat used to define an area in which to measure vegetation. 
2. Determine transect locations and set up the frame at field sites.

- A frequently used monitoring protocol uses two transects, located at least $15 \mathrm{ft}$ $(4.5 \mathrm{~m})$ from the outer edge of the infestation. Try to run individual transects oriented uphill-to-downhill, rather than at the same horizontal position across a hillside: this will be a more effective way to capture agent dispersal and response to environmental gradients.

- Using the measuring tape, stretch the tape in a straight line through the vegetation, being careful not to excessively trample the vegetation. Position the tape so that the area within $3 \mathrm{ft}(0.9 \mathrm{~m})$ of either side of the transect is fairly continuously infested with toadflax. This straight line is the transect.

- Temporarily secure the two ends of the transect with a stake to hold it in place while the quadrat locations are being established.

- Permanently mark each of the transect endpoints with metal or PVC stakes, and record their latitude and longitude or UTM coordinates using a global positioning system (GPS) device. Leaving the transect stakes in place allows the monitoring team to perform the same assessment at the same locations in subsequent years.

3. Record quadrat data. Each site will have 40 quadrats, 20 on each transect.

- Starting from one end of the transect, locate the position of the first quadrat on the transect at the 0 or $3.3 \mathrm{ft}(1 \mathrm{~m})$ position along the tape. Make a note of the starting position (= location of first quadrat) on the data sheet for reference in subsequent field seasons. You can also permanently mark the position of each quadrat with a spike or survey marker (see Fig. 65). It helps to relocate quadrats if transverse corners of each quadrat are permanently marked (e.g., with metal spikes).

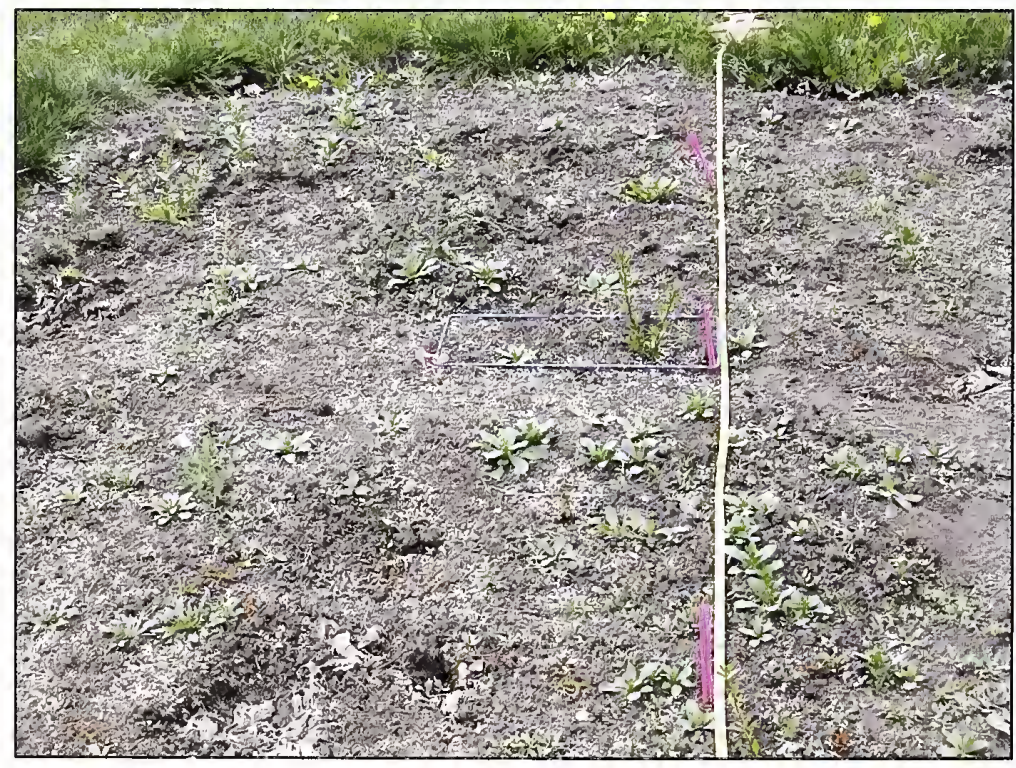

Figure 65. Sample transect with survey markers (hot pink) used to permanently mark quadrat locations for yearly vegetation monitoring. 
4. Monitor toadflax and other vegetation in each quadrat. Directions for a commonly used monitoring protocol are provided in Appendix G. Using the Toadflax Biocontrol - Vegetation Monitoring Form and instructions in Appendix G, do the following:

- Stem counts. Count the number of flowering (= flowers, flower buds or seed capsules) and nonflowering (= no evidence that flowering will occur this year) toadflax stems.

- Stem height measurements. Select the four tallest stems in the quadrat and measure the height of each stem with a yard/meter stick. These data enable you to evaluate how individual plants in the infestation are being affected by biological control.

- Cover estimates. Visually estimate how much of the quadrat is covered with toadflax, grasses, forbs, shrubs, litter, and bare ground (Fig. 66). Personnel may have to be trained in estimating cover classes. Bear in mind that cover estimates are independent because of overlay of layers of vegetation. Thus, the total of all the cover estimates in a plot can be greater than 100 percent. For example, a quadrat can have 60 percent toadflax, 40 percent forb cover, 15 percent grass cover, and 5 percent bare ground.

- Make observations. Note any special features about the site or any changes at the site since the last examination, such as disturbance, grazing, or fire.

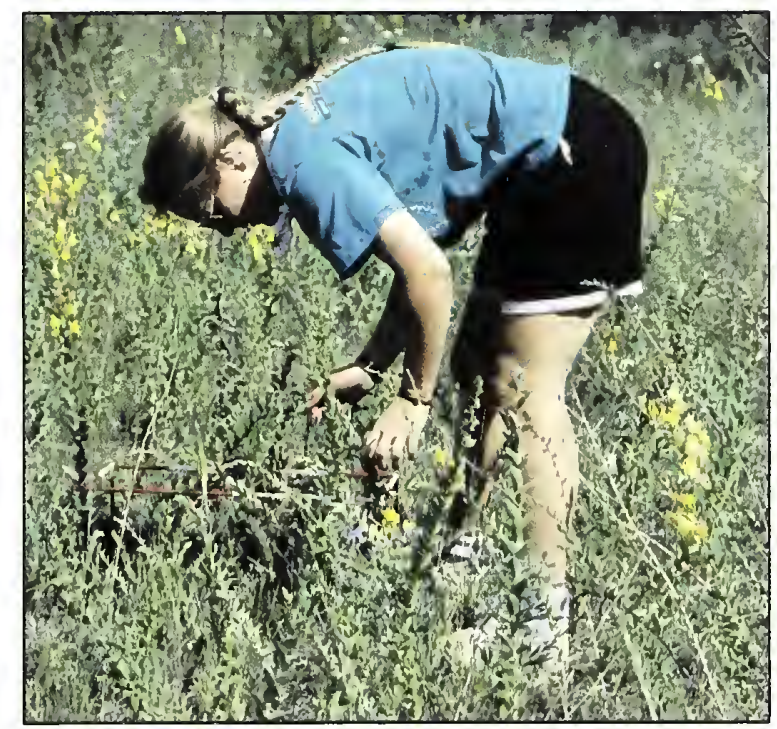

Figure 66. Estimating percent cover of toadflax. 


\section{QUESTION 5: Is the biocontrol agent impacting nontarget plant species?}

\section{SUGGESTED METHOD: Observe plants in the Scrophulariaceae family and other related plant species in the vicinity.}

Some experience in plant identification is needed to answer this question, but personnel can learn to identify toadflax and related plants with a small amount of training. This is particularly true if you can devise a short 'most-wanted' list, comprised of related species or threatened and endangered species that are known to grow in the local area, and provide good descriptions, line drawings, or photographs that effectively and unambiguously identify the species of interest. You may need the assistance of a botanist trained in identifying the local flora for this activity.

Look for native plants in the family Scrophulariaceae that are growing at the site within $50 \mathrm{yd}(46 \mathrm{~m})$ of the biocontrol agent release point. With time, you may have to expand the area of search as agent populations spread. Commonly encountered genera in this family include Penstemon (beardtongue), Castilleja (Indian paintbrush), Mimulus (monkey flower), Collinsia (blue-eyed Mary), Pedicularius (lousewort), and Veronica (speedwell). Plants that are of particular concern are those that are more closely related to the toadflaxes. These include 'Canada toadflax' (Nuttallanthus canadensis) and 'Texas toadflax' (Nuttallanthus texanus), which are native plants once included in the genus Linaria. Additionally, there are a number of native snapdragons (Antirrbinum spp.) that are quite closely-related to exotic toadflaxes; these plants are found primarily in the Sierra foothills of California. (Note: The taxonomy of the Scrophulariaceae is currently undergoing significant revision. Most or all of the native Antirrbinum have been or will be assigned to other genera.)

If any native Scrophulariaceae are found at the site, examine them for the presence of the toadflax agents. If only a single plant or a few plants are present, examine all of them. For large patches of a native plant, survey the entire patch for obvious damage, but 'randomly' select 5-10 plants for the following detailed observations. Look for adult weevils feeding on young foliage and flowers. Record the numbers seen and the relative feeding damage, if any. For the stem-mining weevil, examine the plant stems for any evidence of oviposition scars. For the defoliating moth, look for caterpillars on the young foliage, and record any feeding damage. If agents are found on these plants, place at least some of them in an alcohol-filled vial so that they can be identified. Keep in mind that adult flower-feeding beetles appear to eat the pollen from flowers of many different plant species. Thus, you should examine not only native Scrophulariaceae, but any other plants that are flowering at the time the flowerfeeding beetles are present. 


\section{Selected References}

\section{Toadflax Biology and Ecology}

Alex, J.F. 1962. The taxonomy, history, and distribution of Linaria dalmatica. Can. J. Bot. 40: 295-307.

Arnold, R.M. 1982. Pollination, predation and seed set in Linaria vulgaris (Scrophulariaceae). Am. Midl. Nat. 107: 360-369.

Darwent, A.L., W. Lobay, W. Yarish, and P. Harris. 1975. Distribution and importance in northwestern Alberta of toadflax and its insect enemies. Can. J. Plant Sci. 55: 157-162.

De Clerck-Floate, R., and K.W. Richards. 1997. Pollination ecology and biocontrol: developing release strategies for seed feeding insects on Dalmatian toadflax. Acta Hortic. (Wageningen) 437: 379-384.

Docherty, Z. 1982. Self-incompatibility in Linaria. Heredity 49: 349-352.

Gates, D.H., and W.C. Robocker. 960. Revegetation with adapted grasses in competition with Dalmatian toadflax and St. Johnswort. J. Range Manage. 13: $322-326$.

Grieshop, M.J., and R.M. Nowierski. 2002. Selected factors affecting seedling recruitment of Dalmatian toadflax. J. Range Manage. 55: 612-619.

Harris, P., and M.J. Clapperton. 1997. An exploratory study on the influence of vesicular-arbuscular mycorrhizal fungi on the success of weed biocontrol with insects. Biocontrol Sci. Technol. 7:193-201.

Lajeunesse, S.E., P.K. Fay, D. Cooksey, J.R. Lacey, R.M. Nowierski, and D. Zamora. 1993. Dalmatian and yellow toadflax: weeds of pasture and rangeland. Montana State Univ. Ext. Bull. 115.

Mitich, L.W. 1993. Intriguing world of weeds: yellow toadflax. Weed Technol. 7: $791-793$. 
Nadeau, L.B., and J.R. King. 1991. Seed dispersal and seedling establishment of Linaria vulgaris Mill. Can. J. Plant Sci. 71: 771-782.

Nadeau, L.B., M.R.T. Dale, and J.R. King. 1991. The development of spatial pattern in shoots of Linaria vulgaris (Scrophulariaceae) growing on fallow land or in a barley crop. Can. J. Bot. 69: 2539-2544.

Nadeau, L.B., J.R. King, and K.N. Harker. 1992. Comparison of growth of seedlings and plants grown from root pieces of yellow toadflax (Linaria vulgaris). Weed Sci. 40: 43-47.

Robocker, W.C. 1968. Control of Dalmatian toadflax. J. Range Manage. 21: 9498.

Robocker, W.C. 1970. Seed characteristics and seedling emergence of Dalmatian toadflax. Weed Sci. 18: 720-725.

Robocker, W.C. 1974. Life history, ecology, and control Dalmatian toadflax. Wash. Agric. Exp. Sta. Tech. Bull. 79. Wash. State Univ., Pullman.

Robocker, W.C., R. Schirman, and B.A. Zamora. 1972. Carbohydrate reserves in roots of Dalmatian toadflax. Weed Sci. 20: 212-214.

Rose, K.K., T.D. Whitson, and D.W. Koch. 1999. The competitive effects of five cool-season grasses on Dalmatian toadflax (Linaria genistifolia spp. dalmatica). Proc. West. Soc. Weed Sci. 52: 64-67.

Saner, M.A., D.R. Clements, M.R. Hall, D.J. Doohan, and C.W. Crompton. 1995. The Biology of Canadian Weeds. 105. Linaria vulgaris Mill. Can. J. Plant Sci. 75: 525-537.

Vujnovic, K., and R.W. Wein . 1997. The Biology of Canadian Weeds. 106. Linaria dalmatica (L.) Mill. Can. J. Plant Sci. 77:483-491.

\section{Classification}

Caldara, R. 2001. Phylogenetic analysis and higher classification of the tribe Mecinini (Coleoptera: Curculionidae, Curculioninae). Koleopterol. Rundsch. 71: 171-203.

Ghebrehiwet, M., B. Bremer, and M. Thulin. 2000. Phylogeny of the tribe Antirrhineae (Scrophulariaceae) based on morphological and $n d h \mathrm{~F}$ sequence data. Plant Syst. Evol. 220: 223-239.

Kartesz, J. T., and C.A. Meacham. 1999. Synthesis of the North American Flora, Version 1.0. North Carolina Botanical Garden, Chapel Hill, NC. 
Olmstead, R.G., C.W. dePamphilis, A.D. Wolfe, N.D. Young, W.J. Elisons, and P.A. Reeves. 2001. Disintegration of the Scrophulariaceae. Am. J. Bot. 88: 348 361.

\section{Toadflax Control}

Baig, M.N., A.L. Darwent, K.N. Harker, and J.T. O’Donovan. 1999. Preharvest applications of glyphosate for yellow toadflax (Linaria vulgaris) control. Weed Technol. 13: 777-782.

Duncan, C.A., S.A. Dewey, and M.B. Halstvedt. 1999. The effect of picloram and picloram plus 2,4-D on Dalmatian toadflax control. Proc. West. Soc. Weed Sci. 52: $73-74$.

Gates, D.H., and W.C. Robocker. 1960. Revegetation with adapted grasses in competition with Dalmatian toadflax and St. Johnswort. J. Range Manage. 13: $322-326$.

Robocker, W.C. 1968. Control of Dalmatian toadflax. J. Range Manage. 21: 9498.

Rose, K.K., T.D. Whitson, and D.W. Koch. 1999. The competitive effects of five cool-season grasses on Dalmatian toadflax (Linaria genistifolia spp. dalmatica). Proc. West. Soc. Weed Sci. 52: 64-67.

\section{Biological Control - General}

De Clerck-Floate, R. A., and P. Harris. 2002. Linaria dalmatica (L.) Miller, Dalmatian toadflax (Scrophulariaceae), pp. 368-374. In P.G. Mason and J.T. Huber (eds.), Biological Control Programmes in Canada, 1981-2000. CABI Publishing, Wallingford, Oxon, UK.

Gassmann, A., and C. Paetel. 1998. Investigations on potential biocontrol agents of Dalmatian and yellow toadflax. CABI Bioscience European Centre, Delèmont, Switzerland. Annual Report. 27 p.

McClay, A.S. 1996. Biological control in a cold climate: temperature responses and climatic adaptation of weed biocontrol agents, pp. 377-383. In V.C. Moran and J.H. Hoffmann (eds.), Proc. IX Int. Symp. Biol. Control Weeds, Stellenbosch, South Africa. Univ. of Cape Town, Cape Town, South Africa.

McClay, A.S. 2003. Field releases and evaluation of two biological control agents for common toadflax. Final report for Alberta Agricultural Research Institute Project No. 990034. Alberta Research Council. 43 p. 
McClay, A.S., and R.A. De Clerck-Floate. 2002. Linaria vulgaris Miller, yellow toadflax (Scrophulariaceae), pp. 375-382. In P.G. Mason and J.T. Huber (eds.), Biological Control Programmes in Canada, 1981-2000. CABI Publishing, Wallingford, Oxon, UK.

McFadyen, R.E.C. 1998. Biological control of weeds. Annu. Rev. Entomol. 43: 369-393.

Nowierski, R.M. 1995. Dalmatian toadflax, pp. 312-317. In J.R. Nechols, L.A. Andres, J.W. Beardsley, R.D. Goeden, and C.G. Jackson (eds.), Biological Control in the Western United States: Accomplishments and Benefits of Regional Research Project W-84, 1964-1989. Univ. Calif. Div. Agric. Nat. Res. Publ. 3361, Oakland, CA.

Paetel, C. 1997. Investigations on potential biocontrol agents of Dalmatian and yellow toadflax, Linaria dalmatica and L. vulgaris. Intl. Inst. Biol. Control, Delémont, Switzerland. Annual Report. 22 p.

Paetel, C., and D. Schroeder. 1995. Investigations on potential biocontrol agents of Dalmatian and yellow toadflax, Linaria dalmatica and L. vulgaris. Intl. Inst. Biol. Control, European Station, Delémont, Switzerland. Annual Report. 14 p.

Rees, N.E., P.C. Quimby, Jr., G.L. Piper, E.M. Coombs, C.E. Turner, N.R. Spencer, and L.V. Knutson. 1996. Biological Control of Weeds in the West. Western Society of Weed Science, USDA/ARS, Montana Dept. Agric., Montana State Univ., Bozeman, MT.

Saner, M.A., P. Jeanneret, and H. Müller-Schärer. 1994. Interaction among two biological control agents and the developmental stage of their target weed, Dalmatian toadflax, Linaria dalmatica (L.) Mill. (Scrophulariaceae). Biocontrol Sci. Technol. 4: 215-222.

\section{Brachypterolus pulicarius}

Grubb, R.T., R.M. Nowierski, and R.L. Sheley. 2002. Effects of Brachypterolus pulicarius (L.) (Coleoptera: Nitidulidae) on growth and seed production of Dalmatian toadflax, Linaria genistifolia ssp. dalmatica (L.) Maire and Petitmengin (Scrophulariaceae). Biol. Control 23: 107-114.

Harris, P. 1961. Control of toadflax by Brachypterolus pulicarius (L.) (Coleoptera: Nitidulidae) and Gymnetron antirrbini (Payk.) (Coleoptera: Curculionidae) in Canada. Can. Entomol. 93: 977-981.

Hervey, G.E.R. 1927. A European nitidulid, Brachypterolus pulicarius L. (Coleoptera, family Nitidulidae). J. Econ. Entomol. 20: 809-814. 
McClay, A.S. 1992. Effects of Brachypterolus pulicarius (L.) (Coleoptera: Nitidulidae) on flowering and seed production of common toadflax. Can. Entomol. 124: 631-636.

Nowierski, R.M. 2004. Brachypterolus pulicarius, pp. 383-384. In E. M. Coombs, J.K. Clark, G.L. Piper, and A.F. Cofrancesco, Jr. (eds.), Biological Control of Invasive Plants in the United States. Oregon State Univ. Press, Corvallis.

\section{Calophasia Iunula}

Breitenfeldt, T.A. 1995. Age-specific life table studies of potential strains or host races of Calophasia lunula (Lepidoptera: Noctuidae) (Hufn.) reared on Dalmatian toadflax, Linaria genistifolia ssp. dalmatica (L.) Maire and Petitmengen, or yellow toadflax, Linaria vulgaris (Mill.). M.S. Thesis. Montana State Univ., Bozeman, MT.

Bucher, G.E., and P. Harris. 1968. Virus diseases and their interaction with food stress in Calophasia lunula. J. Invertebr. Pathol. 10: 235-244.

Harris, P. 1963. Host specificity of Calophasia lunula (Hufn.) (Lepidoptera: Noctuidae). Can. Entomol. 95: 101-105.

Hoel, C.J. 1984. A preliminary evaluation of mass rearing of Calophasia lunula (Lepidoptera: Noctuidae) for biological control of toadflax, with emphasis on diapause. M.S. Thesis, Univ. Wyoming, Laramie.

McClay, A.S., and R.B. Hughes. 1995. Effects of temperature on development rate, distribution, and establishment of Calophasia lunula (Lepidoptera: Noctuidae), a biocontrol agent for toadflax (Linaria spp.). Biol. Control 5: 368377.

McDermott, G.J., R.M. Nowierski, and J.M. Story. 1990. First report of establishment of Calophasia lunula Hufn. (Lepidoptera: Noctuidae) on Dalmatian toadflax, Linaria genistifolia ssp. dalmatica (L.) Maire and Petitmengin, in North America. Can. Entomol. 122: 767-768.

\section{Eteobalea intermediella and E. serratella}

Mitchell, A., A.S. McClay, G.R. Pohl, and F.A.H. Sperling. 2005. PCR-based methods for identification of two Eteobalea species (Lepidoptera: Cosmopterigidae) used as biocontrol agents of weedy Linaria species (Scrophulariaceae). Can. Entomol. 137: 129-137. 
Nowierski, R.M. 1994. An environmental assessment of Eteobalea intermediella Riedl and Eteobalea serratella Treitschke (Lepidoptera: Cosmopterygidae), two suitable agents for the biological control of Dalmatian toadflax and yellow toadflax. Department of Entomology, Montana State Univ., Bozeman, MT. Unpublished Report. 44 p.

Saner, M.A., and H. Müller-Schärer. 1994. Impact of root mining by Eteobalea spp. on clonal growth and sexual reproduction of common toadflax, Linaria vulgaris Mill. Weed Res. 34: 199-204.

Saner, M.A., K. Groppe, and P. Harris. 1990. Eteobalea intermediella Riedl and E. serratella Treitschke (Lep., Cosmopterigidae), two suitable agents for the biological control of yellow and Dalmatian toadflax in North America. Int. Inst Biol. Control, European Station, Delémont, Switzerland. Final Report. 37 p.

Saner, M.A., P. Jeanneret, and H. Müller-Schärer. 1994. Interaction among two biological control agents and the developmental stage of their target weed, Dalmatian toadflax, Linaria dalmatica (L.) Mill. (Scrophulariaceae). Biocontrol. Sci. Technol. 4: 215-222.

Volenberg, D.S., H.J. Hopen, and G. Campobasso. 1999. Biological control of yellow toadflax (Linaria vulgaris) by Eteobalea serratella in peppermint (Mentha piperita). Weed Sci. 47: 226-232.

\section{Mecinus janthinus}

Carney, V.A. 2003. Ecological interactions of biological control agent, Mecinus janthinus Germar, and its target host, Linaria dalmatica (L.) Mill. M. Sc. Thesis, University Lethbridge, Lethbridge, Alberta, Canada.

Carney, V.A., J. Rau, S.M. Little, and R.A. De Clerck-Floate. 2004. Rapid differentiation of the sexes of adult Mecinus janthinus Germar (Coleoptera: Curculionidae) based on external leg morphology. Can. Entomol. 136: 835-837.

De Clerck-Floate, R., and V. Miller. 2002. Overwintering mortality of and host attack by the stem-boring weevil, Mecinus janthinus Germar, on Dalmatian toadflax (Linaria dalmatica (L.) Mill.) in western Canada. Biol. Control 24: 6574 .

Jeanneret, P., and D. Schroeder. 1991. Mecinus janthinus Germar (Coleoptera: Curculionidae): a candidate for the biological control of Dalmatian and yellow toadflax in North America. Intl. Inst. Biol. Control, European Station, Delémont, Switzerland. Final Report. 32 p. 
Jeanneret, P., and D. Schroeder. 1992. Biology and host specificity of Mecinus janthinus Germar (Col.: Curculionidae), a candidate for the biological control of yellow and Dalmatian toadflax, Linaria vulgaris (L.) Mill. and Linaria dalmatica (L.) Mill. (Scrophulariaceae) in North America. Biocontrol Sci. Technol. 2: 2534.

Nowierski, R.M. 1994. An environmental assessment of Mecinus janthinus Germar (Coleoptera: Curculionidae), a suitable agent for the biological control of Dalmatian toadflax and yellow toadflax. Dept. of Entomology, Montana State Univ., Bozeman. Unpublished Report. 43 p.

Nowierski, R.M. 2004. Mecinus janthinus, pp. 392-395. In E. M. Coombs, J. K. Clark, G. L. Piper, and A. F. Cofrancesco, Jr. (eds.), Biological Control of Invasive Plants in the United States. Oregon State Univ. Press, Corvallis.

\section{Rhinusa antirrhini (formerly Gymnetron antirrhini), $\boldsymbol{R}$. neta (formerly G. netum), and $\boldsymbol{R}$. linariae (formerly G. linariae)}

Groppe, K. 1992. Gymnetron antirrbini Paykull (Col.: Curculionidae). A candidate for biological control of Dalmatian toadflax in North America. Intl. Inst. Biol. Control, European Station, Delémont, Switzerland. Final Report. 22 p.

Jordan, K. 1994. Gymnetron linariae Panzer (Col.: Curculionidae). A candidate for biological control of Dalmatian and yellow toadflax in North America. Intl. Inst. Biol. Control, European Station, Delémont, Switzerland. Final Report. 36 p.

Nowierski, R.M. 1994. An environmental assessment of Gymnetron antirrhini (Paykull) (Coleoptera: Curculionidae), a suitable agent for the biological control of Dalmatian toadflax. Dept. of Entomology, Montana State Univ., Bozeman, MT. Unpublished Report. 33 p.

Smith, J.M. 1959. Notes on insects, especially Gymnetron spp. (Coleoptera: Curculionidae), associated with toadflax, Linaria vulgaris Mill. (Scrophulariaceae), in North America. Can. Entomol. 91: 116-121.

\section{Toadflax Internet Resources}

\section{Toadflax Identification and Distribution}

http://www.ag.ndsu.nodak.edu/

http://www.agri.state.id.us/

http://www.ceris.purdue.edu/ 
bttp://www.co.gilpin.co.us/

http://www.colostate.edu/

http://www.co.mesa.co.us

http://www.cwma.org/

http://www.ext.colostate.edu/

http://www.extension.usu.edu/

http://www.fs.fed.us/

http://wwwintegratedweedcontrol.com/

http://www.jhwma.org/

http://www.mtweed.org/

http://www.mtwow.org/

http://www.npwrc.usgs.gov/

http://www.nwcb.wa.gov/

http://www.oneplan.org/

http://www.pi.cdfa.ca.gov/

http://www.plants.usda.gov/

http://www.weedcenter.org/

bttp://www.weedsbc.cal

http://www.wildflowers-and-weeds.com/

http://www.wssa.net

\section{Biological Control of Toadflax}

http://res2.agr.ca

http://www.ceris.purdue.edu

http://www.co.stevens.wa.us

http://www.ext.colostate.edu 
http://www.for.gov.bc.ca

http://www.forestryimages.org

http://www.gov.mb.ca

http://www.insectimages.org

http://www.invasive.org

http://www.mtweed.org

bttp://www.nwcb.wa.gov

http://www.nysaes.cornell.edu/ent/biocontrol

http://www.wildflowers-and-weeds.com/weedsinfo/Linaria_spp.htm 


\section{GlOSSARY}
abdomen
The last of the three insect body regions; usually con- taining the digestive and reproductive organs.
adventitious bud
A vegetative bud on a plant root that can sprout to grow a new plant.
alternate
Leaves that are arranged singly at each node along a stem.
axillary
Located in or arising from an axil of a leaf or stem.
biotype
An informal subdivision of a species; generally, refers to a group of organisms that are morphologically identical to other individuals of a species but possess distinctive physiological characteristics (e.g., able to attack a normally resistant host, or not susceptible to a pesti- cide).
capsule
A pod or seed vessel made of two or more cells, that becomes dry and splits open when mature to release its seeds.
caterpillar
The larval stage of a moth or butterfly (Order: Lepi- doptera).
classical biological control
A biological control strategy employing the release in one region of natural enemies imported from another region; typically directed against exotic pests and uses natural enemies from areas where the pest is native.
cocoon The silken case spun by a moth or butterfly larva in which it then pupates. 
competition

complete metamorphosis

community

cover

density

dispersal

elytron (pl. elytra)

emergence

exoskeleton

exotic

field insectary

flower beetle

forb
Negative interactions between individuals of the same or different species that utilize the same resource(s); if the resource is in short supply, one individual or species may survive and increase in number at the expense of the other(s).

A type of insect development characterized by immature stages (larvae and pupae) that look quite different from the adults, and typically live in different habitats, eat different foods, and exhibit different behaviors than do the adults.

A naturally-occurring group of different species of organisms that live together and interact as a more or less self-contained 'unit'.

The portion of the vegetative canopy in a fixed area attributable to an individual or a single plant species.

Number of individuals per unit area.

The spread of animals and plants from any point; the redistribution of plant seeds, fungal spores, or insect eggs, larvae, and adults.

Hardened forewing of a beetle.

Act of adult insect leaving the pupal case or reappearing after overwintering.

Hard, outer frame of an insect that provides structure.

Not native; deliberately or accidentally introduced into an area where it does not naturally occur.

An area where host plants or animals are abundant and biological control agents are released and propagated with or without additional human manipulation.

A small beetle in the family Kateridae, the adults and larvae of which consume flowers and/or seeds of host plants.

A herbaceous plant that is not a grass nor grass-like in form. 
frass

gall

host

host range

host specificity

hybrid

instar

invasive plant

larva (pl. larvae)

metabolic sink

membranous

molt (also moult)

monoculture
The excrement produced by insects, especially larvae, that contains feces and undigested plant material and is often used to detect individuals feeding inside plant tissues.

A plant tumor; a localized proliferation of abnormal plant tissue that is induced by an insect, nematode, fungus, or other organism, and usually exhibits a characteristic shape and color; gall-making insects usually live and feed within the gall.

The plant or animal on which an organism feeds; the organism utilized by a parasitoid; a plant or animal susceptible to attack by a pathogen.

The variety of hosts or host species that may be utilized by a plant- or animal-feeding organism.

The dietary restriction of an organism to a single or limited food (for herbivores: the number of plant species accepted as food); the highly-evolved, often obligatory association between an insect and its host(s); the degree to which an organism is restricted to a particular number of plant or animal hosts.

The offspring of two parents of different species.

The period or stage between successive molts in a insect larva.

An aggressive and dominant plant; likely to colonize and become established in new habitats; usually refers to weeds.

Immature insect stage between the egg and pupa.

Any living cell, tissue, organ, or structure (e.g., gall) that is a storage depot.

Thin and transparent.

The process by which insects and other arthropods shed their exoskeleton ("skin") as they grow and develop; among insects, molting is typically restricted to larval or nymphal stages.

An area vegetated by a single plant species. 
natural enemies

nectar

nontarget effects

noxious weed

ovary

oviposit

perennial

pupa (pl. pupae) (v. pupate)

quadrat

qualitative

quantitative

quarantine facility

random sample

rosette

self-incompatible

snout

synchrony
The predators, parasites, and pathogens closely associated with a plant or animal population.

A sugar-containing secretion produced by plants, usually in flowers, that often attracts insect pollinators.

A non-pest plant that is unintentionally damaged by a biocontrol agent.

A weed whose control is mandated, and whose movement is regulated by federal or state law.

In plants, the expanded basal portion of the pistil that contains the ovules.

To lay or deposit eggs.

A plant living more than two years.

Nonfeeding, inactive stage between the larva and adult in insects.

A specific area used to sample vegetation (e.g., 1 square meter).

Measurement of descriptive elements (e.g., age class, distribution).

Measurement of number or amount (e.g., number of seeds per capsule).

A carefully controlled facility in which exotic or other potentially dangerous organisms can be held and studied with little or no risk of premature escape into the environment.

A sample obtained in such a way that all members of a population have an equal likelihood of examination or collection; an unbiased sample.

A cluster of leaves arranged in circle, usually located basally at or near ground level.

Inability to produce seed and fruit without crosspollination.

The prolongation of the head of a weevil.

Occurring at the same time. 
thorax

transect

vegetative reproduction

viability

voucher specimen

weevil
Body region of an insect behind the head, bearing the legs and wings.

A straight line or path through an area.

Reproduction in plants other than by seeds, such as from rhizomes, stolons, and from nodes on lateral, often creeping, roots.

The proportion of propagules (e.g., seeds) that are alive and can germinate.

A specimen collected from a population of a biological control agent to confirm the identity of the species present.

A type of plant eating beetle, the adults having distinct snouts of variable lengths. 


\section{ACKNOWLEDGEMENTS}

We thank Eric Coombs (Oregon Department of Agriculture), Robert Nowierski (USDA-CSREES), Susan Turner (British Columbia Ministry of Forests), André Gassmann (CABI Bioscience), Ruth Hufbauer (Colorado State University), and Gilbert Wilson (Hazelton, British Columbia) for their contributions to this manual. We thank Alec McClay, Timothy Collier, and Joseph McCaffrey for reviewing this manual. Thanks also to Mark Riffe of ITX/Forest Health Technology Enterprise Team, USDA Forest Service, Fort Collins, CO, for layout and graphics. We also thank Richard Reardon of the Forest Health Technology Enterprise Team, USDA Forest Service, Morgantown, West Virginia, for providing the funds needed to prepare and publish this manual.

\section{SOURCES OF Figures}

Cover

Figures 1a, 22b, 27, 50, 56b

Figures $1 \mathrm{~b}, 4,5,6,7,8 \mathrm{a}, 9,10,11,13,41$

L. Wilson, University of Idaho

Figures 2, 18, 21, 26, 31, 33, 39, 44, 48, 59

\section{University of Idaho}

Figure 3

E. Goulet, Cornell University

Figures 8b, 22a, 23, 24, 32, 37, 38, 40, 42a, 46

B. Richard, USDA-APHIS-PPQ, Fort Collins, CO

Figures $8 \mathrm{~b}, 34$

R. Hansen, USDA-APHIS-PPQ, Fort Collins, CO

Figures 14, 15, 16

C. Roché, Medford, OR

Figures 12, 19, 20

D. MacKinnon, Colorado State University

Figure 17

Adapted from Biological Control of Weeds in the West, Rees et al. (1996)

Figures 25, 35, 52, 57, 58, 62 G. Piper, Washington State University

Figures 28, 43, 55, 60

E. Coombs, Oregon Department of Agriculture

Figures 30, 36, 47, 53, 63, 64, 66

R. De Clerck-Floate, Agriculture and Agri-Food Canada 
Figure 28, 29, 42b, 45

Figure 49

Figure 51

Figure 54, 56a

Figures 61, 65

Table 1
C. Paetel, CABI Biosciences

$R$. Hansen ( $R$. linariae, $R$. antirrbini), R. De ClerckFloate ( $M$. janthinus, E. intermediella), E. Coombs (C. lunula), S. Turner (B. pulicarius); plant drawing modified from http://mtwow.org/Dalmatian-toadflax-linedrawing.html

M. Moses, University of Idaho

K. Loeffelman, University of Idaho

S. Sing, US Forest Service, Bozeman, MT

R. Hansen (flowers), C. Roché (seeds), North Dakota State Univ. Extension (leaves) 
Appendix A: Code of Best Practices for Biological Control of Weeds Appendix B: Troubleshooting Guide: When Things Go Wrong Appendix C: Toadflax Biocontrol Release Form Appendix D: Toadflax Monitoring Plan Questionnaire Appendix E: Toadflax Biocontrol - Insect Monitoring Form Appendix F: Toadflax Biocontrol - Qualitative Monitoring Form Appendix G: Toadflax Biocontrol - Vegetation Monitoring Form 


\section{Appendix A. Code of Best Practices for Biological Control of Weeds}

1. Ensure target weed's potential impact justifies release of nonendemic agents

2. Obtain multi-agency approval for target

3. Select agents with potential to control target

4. Release safe and approved agents

5. Ensure only the intended agent is released

6. Use appropriate protocols for release and documentation

7. Monitor impact on target

8. Stop releases of ineffective agents, or when control is achieved

9. Monitor impacts on potential nontargets

10. Encourage assessment of changes in plant and animal communities

11. Monitor interaction among agents

12. Communicate results to public

Delegates and participants to the X International Symposium for Biological Control of Weeds, recognizing the need for professional standards in the subdiscipline of classical biological control of weeds, urge practitioners of the subdiscipline to voluntarily adopt the CODE OF BEST PRACTICES FOR CLASSICAL BIOLOGICAL CONTROL OF WEEDS, as published in the proceedings of the Symposium, and to adhere to the principles outlined in the Code.

J. K. Balciunas

USDA-ARS, Exotic and Invasive Weed Research Unit

800 Buchanan Street,

Albany, California USA, 94710 


\section{Appendix B. Troubleshooting Guide: When Things Go Wrong}

This guide is intended to assist those who encounter problems when establishing or monitoring a biological control program for toadflax. It identifies the probable cause of common problems and offers solutions.

\begin{tabular}{|c|c|c|}
\hline Problem & Probable Cause & Solution \\
\hline \multirow[t]{6}{*}{$\begin{array}{l}\text { Biocontrol agents } \\
\text { unhealthy }\end{array}$} & $\begin{array}{l}\text { Physical damage to } \\
\text { agents }\end{array}$ & $\begin{array}{l}\text { Prevent collection containers from colliding; } \\
\text { use crush-resistant containers. } \\
\text { When aspirating, change vials often, avoid } \\
\text { long exposure and crowding in vials. } \\
\text { When sweeping, empty contents of net after } 5 \\
\text { (for moths and flies) or } 25 \text { sweeps (for } \\
\text { beetles). }\end{array}$ \\
\hline & Drowning & $\begin{array}{l}\text { Do not put excess water in the collection } \\
\text { containers. }\end{array}$ \\
\hline & $\begin{array}{l}\text { Excess or prolonged } \\
\text { heat or cold }\end{array}$ & $\begin{array}{l}\text { Keep containers cool at all times; use coolers } \\
\text { and ice packs; avoid exposure to direct } \\
\text { sunlight while in transit. }\end{array}$ \\
\hline & Starvation & $\begin{array}{l}\text { Put toadflax stems with foliage (no flowers, } \\
\text { seeds, or roots) in container; minimize time } \\
\text { agents are in containers. }\end{array}$ \\
\hline & Release delay & $\begin{array}{l}\text { Transport or ship agents immediately after } \\
\text { collection; release agents at new site } \\
\text { immediately upon arrival or receipt of agents. }\end{array}$ \\
\hline & $\begin{array}{l}\text { Parasitism and/or } \\
\text { disease }\end{array}$ & $\begin{array}{l}\text { Check source of agents when obtained from a } \\
\text { supplier; ensure insect population is disease- } \\
\text { free when collecting or receiving shipments. }\end{array}$ \\
\hline \multirow[t]{5}{*}{ Few insects collected } & $\begin{array}{l}\text { Wrong collection } \\
\text { method used }\end{array}$ & $\begin{array}{l}\text { Refer to Table } 5 \text { for recommended collection } \\
\text { time and technique. }\end{array}$ \\
\hline & $\begin{array}{l}\text { Collection done at } \\
\text { wrong time }\end{array}$ & $\begin{array}{l}\text { Refer to Table } 5 \text { for recommended collection } \\
\text { time and technique. }\end{array}$ \\
\hline & $\begin{array}{l}\text { Collection } \\
\text { effectiveness }\end{array}$ & $\begin{array}{l}\text { Insects can be harmed during collecting; } \\
\text { practice aspirating, sweeping, and sorting. }\end{array}$ \\
\hline & $\begin{array}{l}\text { Conditions at time of } \\
\text { collection }\end{array}$ & Collect in favorable weather. \\
\hline & Population size & Agent population still too low to collect. \\
\hline
\end{tabular}




\begin{tabular}{|c|c|c|}
\hline Problem & Probable Cause & Solution \\
\hline \multirow[t]{6}{*}{$\begin{array}{l}\text { Biocontrol agents not } \\
\text { found after release }\end{array}$} & Site is unsuitable & $\begin{array}{l}\text { Refer to "Releasing Biocontrol Agents" } \\
\text { section. }\end{array}$ \\
\hline & Site too small & $\begin{array}{l}\text { Select a larger site and dense stand of } \\
\text { toadflax. }\end{array}$ \\
\hline & Monitoring method & $\begin{array}{l}\text { Monitoring method is inappropriate or } \\
\text { monitoring was done at the wrong time. }\end{array}$ \\
\hline & $\begin{array}{l}\text { Not enough agents } \\
\text { released }\end{array}$ & $\begin{array}{l}\text { Repeat releases with a larger number of } \\
\text { insects. }\end{array}$ \\
\hline & Predation & $\begin{array}{l}\text { Agents may have been killed by ants, spiders, } \\
\text { birds, etc. }\end{array}$ \\
\hline & Bad luck & $\begin{array}{l}\text { Bad weather event, flooding, pesticides, or } \\
\text { other event may kill many or all insects. } \\
\text { Initiate another release. }\end{array}$ \\
\hline \multirow[t]{3}{*}{$\begin{array}{l}\text { Insects do not build up } \\
\text { populations within } \\
\text { years after release }\end{array}$} & $\begin{array}{l}\text { Existing populations } \\
\text { may be too small }\end{array}$ & Release additional insects. \\
\hline & Site unsuitable & $\begin{array}{l}\text { Do not give up: repeat steps outlined above or } \\
\text { try to assess which factors are critical and can } \\
\text { be changed. If after assessing the situation } \\
\text { and making possible changes the agents still } \\
\text { won't establish, be prepared to drop this site. }\end{array}$ \\
\hline & Bad weather & $\begin{array}{l}\text { Unfavorable weather conditions for several } \\
\text { consecutive years can hamper insect } \\
\text { population growth. }\end{array}$ \\
\hline \multirow[t]{2}{*}{$\begin{array}{l}\text { Cannot locate release } \\
\text { site }\end{array}$} & $\begin{array}{l}\text { Permanent location } \\
\text { marker not found }\end{array}$ & $\begin{array}{l}\text { Use bright-colored wooden, metal, or plastic } \\
\text { stake; locate site with GPS coordinates. }\end{array}$ \\
\hline & $\begin{array}{l}\text { Map incorrectly or } \\
\text { poorly drawn }\end{array}$ & $\begin{array}{l}\text { Check map, redraw with more detail, or add } \\
\text { landmarks. }\end{array}$ \\
\hline
\end{tabular}




\section{Appendix C. Toadflax Biocontrol Release Form}

Released By:

Release Date:

State:

County:

Biocontrol Agent:

\# Released:

Source of Agents:

Date Collected:

Life Stage (circle): Larvae Adults

$(m \mathrm{dd}$ yy)

Land Ownership (circle): Private County State USFS BLM COE BOR BIA/Tribe TNC Other (specify)

Legal: $\mathrm{T} \_\mathrm{R} \_$Sec___ Q Lat: Deg__ Min__ Sec___ Long: Deg_ Min_ _ Sec

UTM: UTM Datum Zone: ___ UTM Year:_____ UTM Easting: _________ UTM Northing:

\section{ENVIRONMENT}

Temperature $\left({ }^{\circ} \mathbf{F}\right)$ :

Wind: Calm, Light, Moderate, Strong, Gusty Wind Direction: N S E W

Weather (circle): Clear Ptly Cloudy Cloudy Rain Snow

Release Time:

$\mathrm{AM} / \mathrm{PM}$

Site Aspect (circle): N, NE, E, SE, S, SW, W, NW

Elevation:

Site Slope: Flat $(0-10 \%)$

Gentle (10-30\%)

Moderate $(30-60 \%)$

Steep $(>60 \%)$

Topographic Position (circle): Valley Bottom Terrace Lower Slope Mid/Upper Slope Crest

Disturbance: (check all that apply, circle most prevalent) _ Cultivation __ Fire __ Flood __ Grazing __ Logging

Roads Mining Recreation

\section{SITE CHARACTERISTICS}

Site Name:

Size of Infestation (acres): Estimated \% Weed Cover:

Est. Weed Height $(\mathrm{cm})$ :

Est. Weed Density (\# per meter sq.):

Dominant Plant:

Distribution of Weed: Isolated Scattered___ Sc-Patchy Patchy Coniinuous Linear

Phenology: Seedling \% Rosette \% Bolt $\%$ Bud \% Flowering \% Seed $\%$ Dormant $\%$

Vegetation Type (check):

Grassland

Pasture

Dry Meadow

Moist Meadow

Shrubland Steppe

Conifer Forest

Soil Texture: (check) Sand
Estimate \% Cover:

Tree

Shrub

Forb

Grass

Litter

Bare Ground

Rock

Silt_ Clay_ Gravcl __ Loam 


\section{Toadflax Biocontrol Release Form (side 2)}

\section{CONTACT PERSON:}

Name:

Address:

City:

State:

Phone:

e-mail:

\section{LEGAL LANDOWNER:}

Name:

Address:

City:

State:

Phone:

e-mail:

$\underline{\text { Road Map to Site }}$

$\underline{\text { Site and Vegetation Map }}$

Comments: 


\section{Appendix D. Toadflax Monitoring Plan Questionnaire}

The following is a list of questions to be answered and documented prior to collecting data.

Use the checklist as an outline for a monitoring plan.

What is the management objective of the biocontrol release site?

a) Study site for long-term monitoring

b) Nursery site to increase numbers of agents for future collection and redistribution

c) Open release site, no additional monitoring is intended

Notes:

What will be measured?

a) Biocontrol agent presence/ absence

b) Biocontrol damage to target weed

c) Plant community structure or composition.

Notes:

What equipment and supplies are needed?

What training is needed?

What is the cost of monitoring?

What is the interval bctween monitoring? 


\section{Appendix E. Toadflax Biocontrol - Insect Monitoring Form}

SITE:

STATE:

DATE:

Last name:

First name:

GPS: Lat N

- Long W

Elevation:

ft $m$

UTM: UTM Datum Zone: _ _ UTM Year:

UTM Easting:

UTM Northing:

TIME:

TEMPERATURE:

WEATHER:

1. Counting Biocontrol Agents

This method is used to count adults of the flower-feeding beetle and the stemmining weevil, and caterpillars of the defoliating moth.
What to do

For each agent:
For flower-feeding beetle: Count for 10 minutes

For stem-mining weevil: Count for 5 minutes

For the defoliating moth: Count for 15 minutes

\begin{tabular}{|l|}
\hline Number of agents observed \\
\hline$\square$ No agents observed \\
\hline$\square$ One agent observed \\
\hline $2-10$ agents observed \\
\hline $10-50$ agents observed \\
\hline $50-100$ agents observed \\
\hline$\square>100$ agents observed \\
\hline
\end{tabular}

\begin{tabular}{|l|}
\hline Agent feeding damage \\
\hline$\square$ No agent feeding observed \\
\hline$\square$ Occasional, scattered feeding damage observed \\
\hline$\square$ Conspicuous, widespread feeding damage observed \\
\hline
\end{tabular}

2. Sweep-net or tray sampling

This method is used for the seed-feeding weevils and the root-galling weevil.

What to do For sweep net: Sweep plants 5 times; then count beetles for each sample:

For tray sample: Tap plant 10 times to knock beetles onto a tray; then count

\begin{tabular}{|l|l|l|l|l|l|l|l|}
\hline Sample & Weevils & Sample & Weevils & Sample & Weevils & Sample & Weevils \\
\hline 1 & & 6 & & 11 & & 16 & \\
\hline 2 & & 7 & & 12 & & 17 & \\
\hline 3 & & 8 & & 13 & & 18 & \\
\hline 4 & & 9 & 14 & & 19 & \\
\hline 5 & & 10 & & 15 & & 20 & \\
\hline
\end{tabular}

Total number of weevils collected:

Notes: 


\section{Instructions for Appendix E: Toadflax Biocontrol - Insect Monitoring}

Materials needed: stopwatch, sweep net, monitoring form, pencils, clipboard, camera, and GPS unit to record site location.

General: The purpose of this monitoring activity is to estimate the abundance of toadflax biocontrol agents at your monitoring site. Conduct the monitoring when the biocontrol agents are at their peak emergence.

1) Site information: Fill out the site information at the top of the form.

2) Insect counting: To estimate the density of biocontrol agents, you need to count them. Carefully approach the site and avoid disturbing the vegetation. Adults often drop from the vegetation once you touch stems (or even as you approach the quadrat).

Timed Counting: Schedule monitoring to coincide with the adult stage of the biocontrol agent that you are sampling (or caterpillars of Calophasia). Randomly walk at a steady pace within the observation area, staying within $32 \mathrm{yd}(30 \mathrm{~m})$ of the release point. Accuracy is increased if you avoid backtracking over the same area because both beetles and caterpillars are easily brushed off or fall from toadflax. Beginning at the release point marker, count all the agents you see, concentrating on the top portions of the plants. Count the insects for 5, 10, or 15 minutes, as appropriate, and record the number seen.

Sweep net sampling: Using a sturdy canvas net, sweep the upper 3 in $(10 \mathrm{~cm})$ of the plant along transects $64 \mathrm{ft}(20 \mathrm{~m})$ long. Sweeping lower will give you lots of broken plant parts, but will not necessarily yield any more beetles. Make 20 samples of five sweeps each, sweeping relatively gently through the upper parts of the toadflax plants. Open the net after the five sweeps, count any biocontrol insects collected, then either release the captured insects, or place them in alcohol-filled vials for identity confirmation. You may also empty your sweep net into a white tray for immediate counting, or dump the tray contents into a large plastic cup that you can cover for later counting. The 20 samples can be taken randomly through the toadflax infestation, or by walking in a straight line away from the release point along each cardinal direction (N, S, E, W). For the latter, do five to seven, five-sweep samples at regular intervals (e.g., 10-16 ft (3-5 m) apart) depending on the size of the toadflax patch.

Tray sampling: This method is particularly useful when monitoring low to medium population densities of biocontrol beetles. Use a white or similarly light-colored plastic tray, pan, or other flat receptacle with sides. The tray should be rectangular or square (for ease of tipping collected insects into specimen vials or other containers), and 12-18 in (30-46 cm) on the longest side. Take 20 samples at each release location. For each sample, gently hold one toadflax stem or a handful of toadflax stems and shake or tap the upper stems 10 times over the collecting tray. This should dislodge at least some of the adults present; they can then be easily counted on the tray and released. Twenty to thirty samples may be taken ranulomly throughout the toadflax infestation, or you may collect tray samples walking away from the release point along each cardinal direction (N, S, E, W). For the latter, do five to seven 'beating' samples at regular intervals (e.g., 10-16 ft (3-5 m) apart), depending on the size of the toadflax patch. 


\section{Appendix F. Toadflax Biocontrol - Qualitative Monitoring Form}

SITE:

STATE:

DATE:

Last name:

First name:

GPS: Lat $N$ - Long W

UTM: UTM Datum Zone: _ _ UTM Year:

UTM Easting:

UTM Northing:

TIME:

TEMPERATURE:

WEATHER:

Biocontrol Insect:

Year of release:

Toadflax Species (circle): Dalmatian yellow

\begin{tabular}{|c|c|c|c|c|c|c|c|}
\hline \multicolumn{8}{|c|}{ Cover class estimate by plant category } \\
\hline & $0 \%$ & $1-5 \%$ & $6-25 \%$ & $26-50 \%$ & $51-75 \%$ & $76-95 \%$ & $96-100 \%$ \\
\hline Toadfla & & & & & & & \\
\hline Grasse & & & & & & & \\
\hline Forbs & & & & & & & \\
\hline Shrubs & & & & & & & \\
\hline Trees & & & & & & & \\
\hline
\end{tabular}

Dominant plant species on site:

Other noxious weeds:

\begin{tabular}{|l|l|l|l|}
\hline \multicolumn{4}{|c|}{ Estimate toadflax density class ( $\checkmark$ check one) } \\
\hline \multicolumn{2}{|c|}{ Flowering plants $/ \mathrm{m}^{2}$} & \multicolumn{2}{|c|}{ Toadflax distribution } \\
\hline 0 & & Isolated & \\
\hline $1-25$ & & Scattered & \\
\hline $26-50$ & & Scattered-Patchy & \\
\hline $50-75$ & & Patchy & \\
\hline$>75$ & & Continuous & \\
\hline
\end{tabular}

\begin{tabular}{|l|c|}
\hline \multicolumn{2}{|c|}{ Toadflax phenology class } \\
\hline Toadflax Stage & $\begin{array}{c}\text { Estimated } \\
\text { percent }\end{array}$ \\
\hline Seedling & \\
\hline Rosette & \\
\hline Bolting & \\
\hline Flowering & \\
\hline Senescent & \\
\hline
\end{tabular}

Comments/Observations 


\section{Appendix G. Toadflax Biocontrol - Vegetation Monitoring Form}

SITE:

Last name:

GPS: N

UTM: UTM Datum Zone:

TIME:

TEMPERATURE
STATE:

DATE:

First name:

\begin{tabular}{|c|cc|cc|cc|cc|}
\hline \multirow{2}{*}{$\begin{array}{c}\text { Chart A: } \\
\text { Cover Class }\end{array}$} & Class & $\%$ Cover & Class & $\%$ Cover & Class & $\%$ Cover & $\%$ Cover & Class \\
\cline { 2 - 9 } & 0 & 0 & 2 & $6-25 \%$ & 4 & $51-75 \%$ & 6 & $96-100 \%$ \\
\cline { 2 - 9 } & 1 & $1-5 \%$ & 3 & $26-50 \%$ & 5 & $76-95 \%$ & &
\end{tabular}

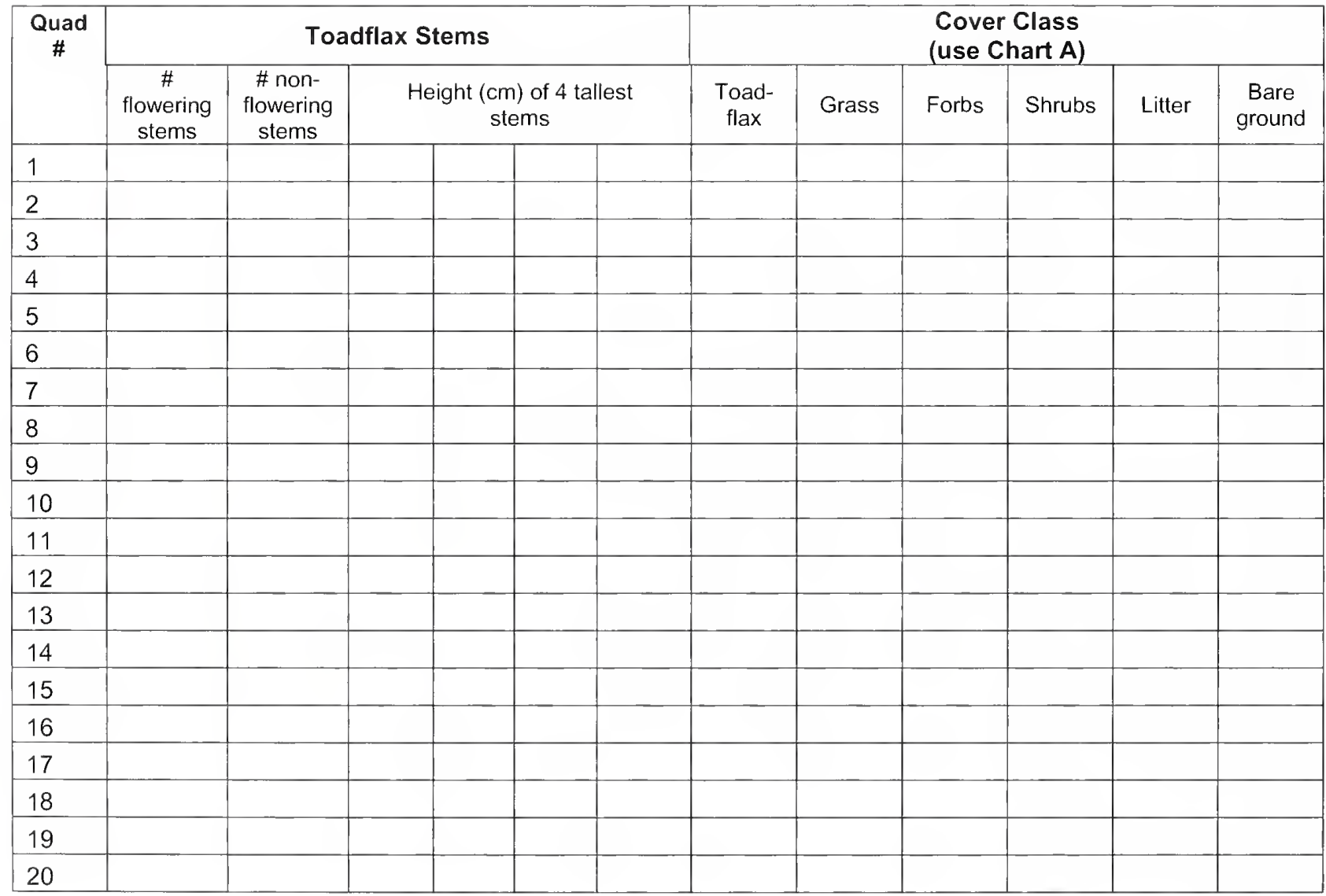

Notes 


\section{Toadflax Biocontrol - Vegetation Monitoring (side 2)}

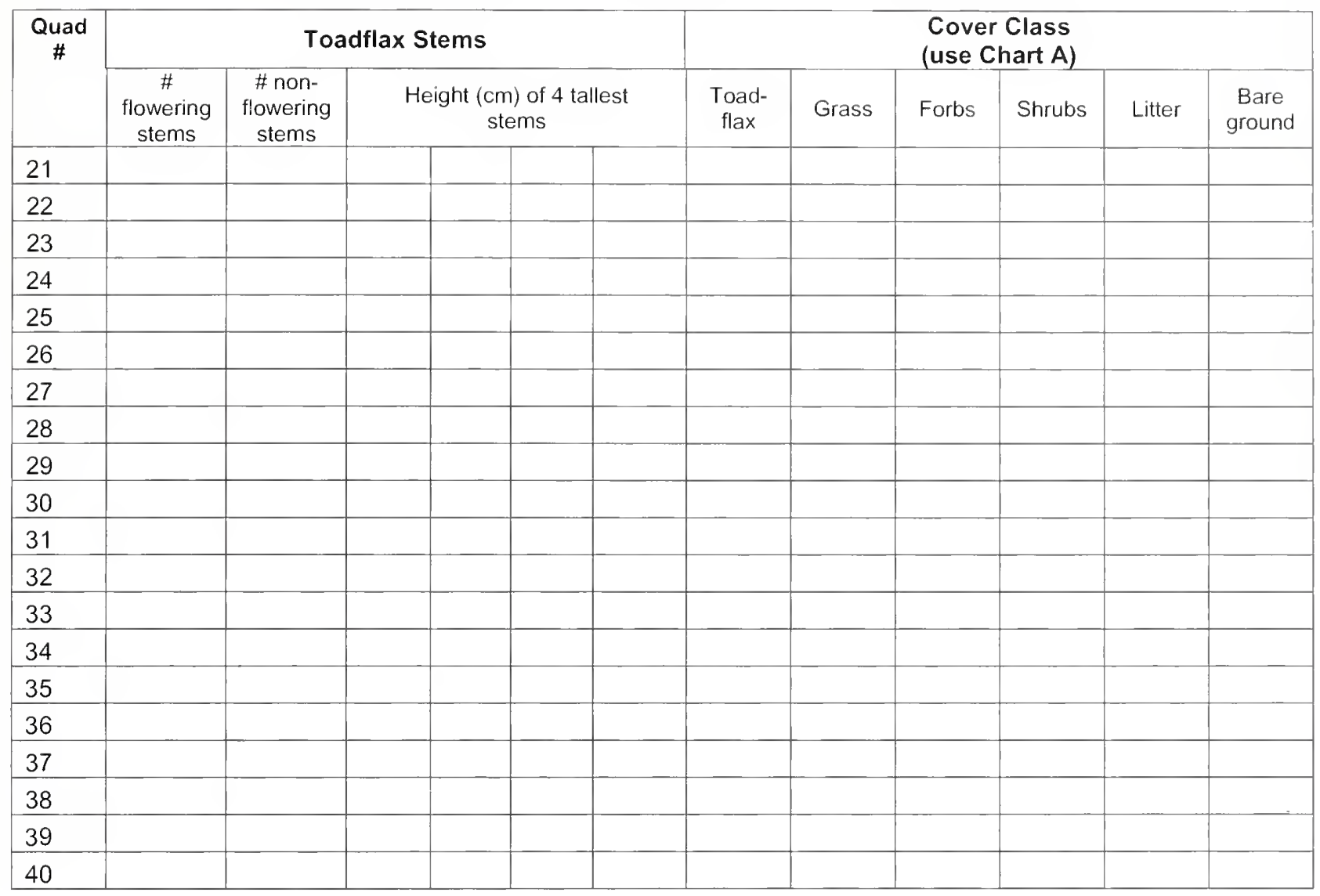

Notes: 


\section{Instructions for Appendix G: Toadflax Biocontrol - Vegetation Monitoring}

Materials needed: $1 \mathrm{yd}(1 \mathrm{~m})$ measuring stick, $3.5 \mathrm{ft}^{2}\left(0.1 \mathrm{~m}^{2}\right)$ quadrat frame, data sheets, pencils, clipboard, camera, and GPS unit to relocate quadrats.

General: The purpose of this activity is to estimate the abundance of toadflax and other vegetation in the community, and to measure toadflax plants. Monitoring is easier with two people, one to make the observations and the other to record data.

1) Site information: Fill out the site information at the top of the form.

2) Locate the transect and position the quadrat: After you have completed the insect counts, locate the transect using the GPS coordinates and the permanent marker.

3) Position the quadrat frame: Position the quadrat frame along the transect, as close to the ground as possible, carefully positioning the quadrat frame along the transect line. Gently arrange vegetation so that plant parts are either within or outside, rather than underneath, the frame, but be sure not to damage the plants. The quadrat should be in the same location as the previous year's quadrat.

4) Count stems: Count the number of toadflax stems, beginning at one corner of the quadrat and working systematically across the quadrat. Count the number of flowering and nonflowering stems.

5) Measure stems: Select the four tallest toadflax stems in each quadrat (if there are fewer than four stems/quadrat, measure all that are present). Measure the stem height to the closest centimeter.

6) Estimate percent cover: Standing over the frame, estimate how much of the quadrat is covered by toadflax, expressed as a percentage. Then estimate the percent cover of grasses, forbs, shrubs, plant litter, and bare ground. Use the cover classes in Chart A to estimate percent cover.

7) Other observations: Record any general observations or useful information such as disturbances, grazing, fire, etc., for the sample quadrat or the site in general. 
NATIONAL AGRICULTURAL LBPARY

.

1022738185 